\title{
Diálogos diversos para más mundos posibles
}

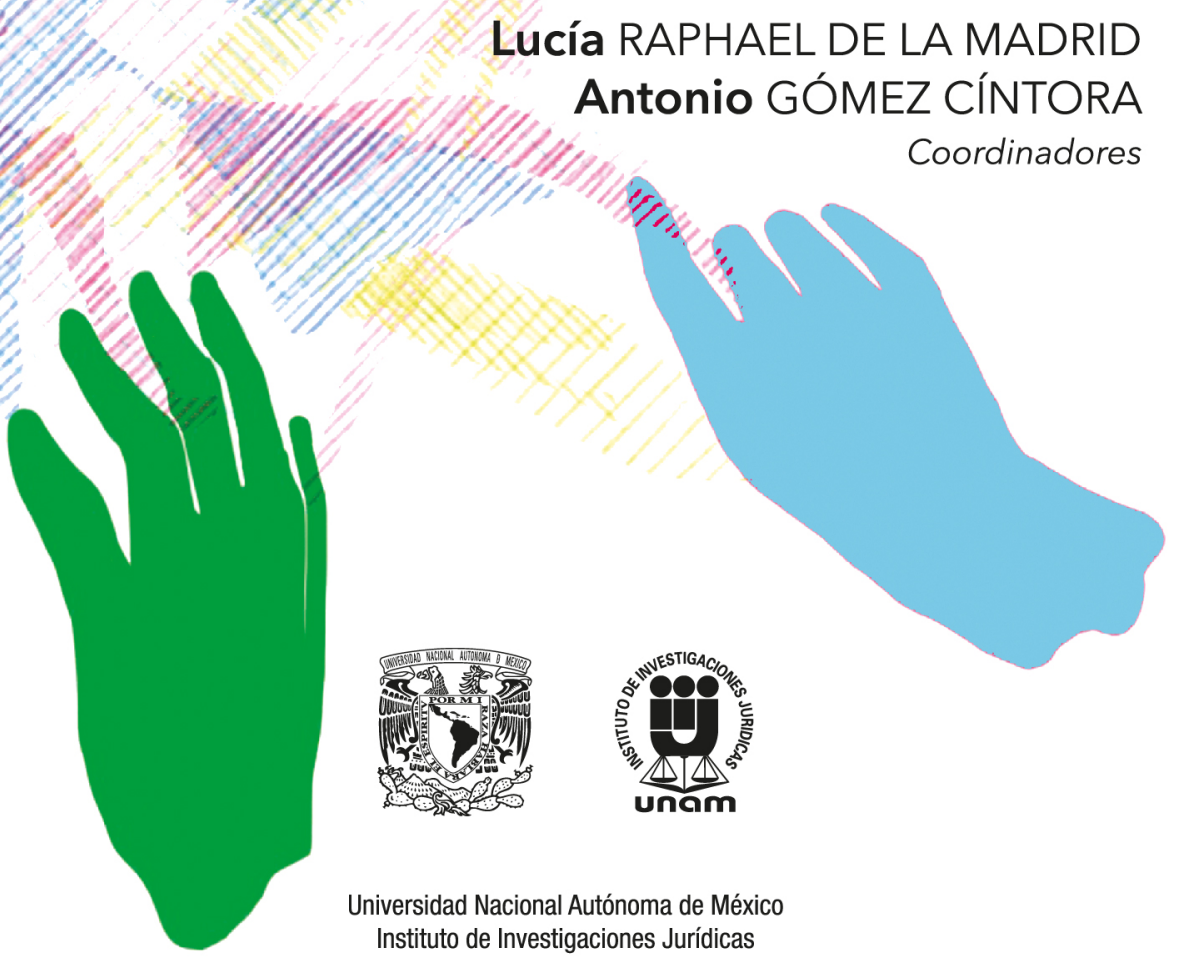




\section{DIÁLOGOS DIVERSOS PARA MÁS MUNDOS POSIBLES}




\title{
INSTITUTO DE INVESTIGACIONES JURÍDICAS
}

Serie Estudios JuRídicos, núm. 317

\section{COORDINACIÓN EDITORIAL}

\author{
Lic. Raúl Márquez Romero \\ Secretario Técnico
}

Lic. Wendy Vanesa Rocha Cacho

Jefa del Departamento de Publicaciones

Wendy Vanesa Rocha Cacho

Cuidado de la edición

José Antonio Bautista Sánchez

Formación en computadora

Sara Chabela

Diseño y elaboración de portada 


\title{
DIÁLOGOS DIVERSOS PARA MÁS \\ MUNDOS POSIBLES
}

\author{
LUCÍA RAPHAEL DE LA MADRID \\ ANTONIO GÓMEz CínTORA \\ Coordinadores
}
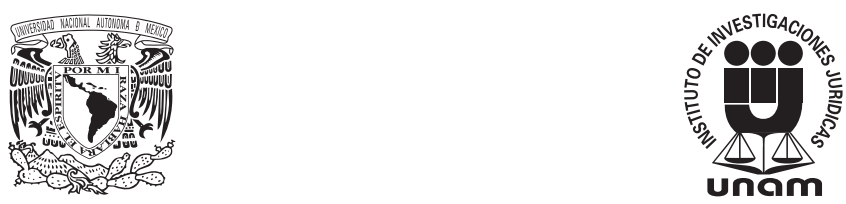

UNIVERSIDAD NAGIONAL AUTÓNOMA DE MÉXICO INSTITUTO DE INVESTIGACIONES JURÍDICAS MÉXICO, 2018 
El proyecto 282035 "Laboratorio Nacional Diversidades", aprobado en la Convocatoria 2017, es parte del Programa de Apoyos Complementarios para el Establecimiento y Consolidación de Laboratorios Nacionales Conacyt. Alojado en el Instituto de Investigaciones Jurídicas de la UNAM, realiza su labor en colaboración con la Facultad Latinoamericana de Ciencias Sociales (FLACSO), el Centro de Investigación y Docencia Económicas (CIDE) y el Consejo Nacional para Prevenir la Discriminación (CONAPRED).
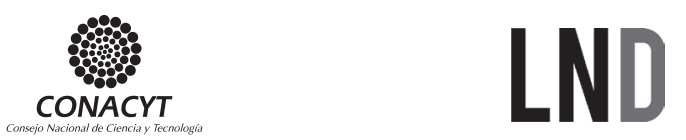

Primera edición: 23 de marzo de 2018

Primera reimpresión: 23 de julio de 2018

DR @ 2018. Universidad Nacional Autónoma de México

INSTITUTO DE INVESTIGACIONES JURÍDICAS

Circuito Maestro Mario de la Cueva s/n

Ciudad de la Investigación en Humanidades

Ciudad Universitaria, 04510 Ciudad de México

Impreso y hecho en México

ISBN 978-607-30-0069-7 


\section{GONTENIDO}

Presentación ........................ IX

Lucía RAPHAEL DE LA MADRID

Antonio GÓmEz GínTORA

De la familia tradicional a la diversidad familiar

Diversidades familiares: espacios de construcción de apertura, justicia y equidad . . . . . . . . . . .

Adriana SEgOVIA URBANO

Reflexiones sobre el derecho de adopción y las familias homoparentales

Lucía RAPHAEL DE LA MADRID

Cuerpos, autonomía y feminismos

Reflexiones sobre el derecho a decidir: de la defensa del aborto a la lucha por la desestigmatización del trabajo sexual. .......................

Iris GONZÁLEz GORTEZ

Territorios posibles para nosotras. Claves interpretativas para leer el ocio festivo . . . . . . . . . . .

Ángela RIVERA MARTÍNEZ

Victoria LÓPEZ Rosete 


\section{Identidades trans}

Ontopolíticas del cuerpo trans: controversia, historia e identidad ....................... 71

Siobhan GUERRERO

Leah MuÑOZ

Patologización y despatologización de las identidades trans y su expresión en la Ciudad de México. Un estudio monográfico ........................ 95

María Fernanda LóPEz LóPEZ

Quebranto: profanar un lugar sagrado y entrar en él sin permiso. . . . . . . . . . . . . . . . . . . . . . . . . . 115 Andrea Angulo Menasse

Reconocer el pasado: el lugar de la adultez en un mundo diverso

El sector más importante y mayoritario en la población mundial en 40 años: personas adultas mayores. . . . . . . Karla Margarita ORTIZ ANTUNA

\section{Grupos indígenas y medios de comunicación autónomos}

Políticas de exclusión en el uso de los medios de comunicación hacia los pueblos indígenas . . . . . . . . . .

Viviana PINEDA PARTIDA 


\section{PRESENTACIÓN}

Sólo tendremos la oportunidad de un diálogo adecuado que atraviese fronteras si los ciudadanos jóvenes saben cómo participar en el diálogo y la deliberación en primer lugar. Y sólo sabrán cómo hacerlo si aprenden a examinarse a sí mismos y a pensar en las razones por las que son proclives a apoyar una causa y no otra. ${ }^{1}$

En su primer año de existencia, el Laboratorio Nacional Diversidades UNAM-Conacyt, creado en la convocatoria 2017, se presenta como una iniciativa que busca impulsar el diálogo entre las distintas áreas que componen la Universidad Nacional Autónoma de México y los diversos grupos sociales que conforman nuestro país mediante actividades académicas que fomenten un renovado aprecio por la diversidad humana en cualquiera de sus manifestaciones.

Actualmente, en México hemos sido testigos de cómo una parte de nuestra sociedad, aquella que se identifica como de carácter conservador, ha endurecido sus posturas sociales y políticas contra la diversidad social, política y cultural de nuestra sociedad. En el mundo actual se robustecen cada vez más las posturas que niegan, agreden y aniquilan las diferencias culturales, sociales e identitarias a partir de, por lo menos, seis elementos: 1) una con-

1 Nussbaum, Martha, "El duro discurso de MN sobre el futuro de la educación mundial", El Heraldo, Colombia, 13 de diciembre de 2015, p. 8. 
cepción eurocéntrica de la vida; 2) la tendencia a fortalecer los privilegios de los grupos sociales dominantes en detrimento de la mayoría de personas; 3) una concentración inmoral de la riqueza global; 4) el preocupante desmantelamiento de los derechos humanos; 5) el rechazo abierto a las diversidades, y 6) la construcción social del otro, el diferente o desconocido como el enemigo.

Los avances que en la historia del pensamiento occidental se habían relativamente logrado a favor del respeto y la valoración de las diversidades, la capacidad de los seres humanos para reconocer en las diferencias una riqueza invaluable para el desarrollo de nuestra civilización, han sufrido un cambio de dirección preocupante hacia la aceptación irreflexiva de una mirada excluyente, androcéntrica, ignorante; azuzada por el miedo y la ausencia de entendimiento al distinto.

Conscientes de la emergencia, y de la urgencia, en generar contrapesos que fomenten el entendimiento entre nuestras propias diferencias, además de sensibilizar sobre los alcances destructivos de mantener una sociedad cada vez más individualista, controlada por lo que la filósofa norteamericana Martha Nussbaum llama "el choque de civilizaciones dentro de cada persona"; este laboratorio de humanidades - a la manera de Michel de Montaigne - ${ }^{2}$ entiende la vida como un ensayo (essai), un perenne intento de prueba y error que genera un espacio para la reflexión donde podamos pensarnos juntos, desde nuestras propias diferencias, y fortalecer nuestra capacidad de entender y respetar a las demás personas desde la ética del otro. Siguiendo a Nussbaum, este choque interno "se puede encontrar en todas las sociedades modernas, en [sus] diferentes formas, ya que todas contienen luchas por la inclusión y la igualdad, ya esté en el centro neurálgico de estas luchas en los debates sobre la inmigración, o en la reconciliación de las minorías religiosas, raciales y étnicas, o en la igualdad de género o en la discriminación positiva...". ${ }^{3}$

2 Filósofo francés del siglo XVI.

3 Nussbaum, Martha, "El duro discurso de MN sobre el futuro de la educación mundial", op. cit., p. 8. 
El trabajo que ahora tienen en sus manos queridxs lectorxs, inaugura el ejercicio bibliográfico que el Laboratorio Nacional Diversidades emprende para sumar a todos los materiales realizados para el ámbito universitario, y no sólo para él, en la creación de pautas y referencias de aprendizaje que apoyen un diálogo indispensable para repensar los procesos de educación, las políticas públicas, la ética del cuidado; siempre a partir de un pensamiento crítico, como elemento necesario para la formación de una buena ciudadanía en una sociedad que tiene que saber luchar por conseguir su propio desarrollo.

En este volumen se presentan cinco ejes temáticos desarrollados a partir de los trabajos y líneas de investigación de las personas especialistas que integran el equipo del Laboratorio y que conforman un espacio para pensar y reflexionar juntos la trascendencia de las diversidades como centro de estudio de nuestras áreas, a través de todos los espacios y herramientas que un Laboratorio Nacional puede generar.

En el bloque llamado De la familia tradicional a la diversidad familiar se presentan dos textos que abordan, desde diferentes perspectivas, la diversidad familiar. De la mano de Adriana Segovia Urbano revisamos algunas reflexiones sobre su amplia experiencia, tanto teórica como clínica, en el trabajo con familias y en lo que la autora llama "la construcción de una cultura basada en la apertura, el respeto y la equidad", que tome como marco de referencia la visibilización de la diversidad familiar. A partir del planteamiento de la familia como un modelo jerárquico y desigual por sí mismo, expone y dialoga con los trabajos del argentino Salvador Minuchin y el australiano Michael White sobre sus concepciones de diversidad y su posible aplicación a la diversidad familiar. Lucía Raphael de la Madrid nos ofrece reflexiones sobre el derecho de adopción en parejas homoparentales, en el contexto del avance de los derechos alcanzados en la Ciudad de México y en algunos estados de la República Mexicana. El análisis a que nos convoca este texto concierne a la idea central de que "el tema de la adopción por parejas del mismo sexo tiene que 
ver con la expresión y la legitimación ante la sociedad de que las uniones homosexuales son tan válidas como las uniones heterosexuales"; esta idea que persiste en nuestras sociedades contemporáneas genera efectos sociales adversos al ejercicio de derechos de las familias que no responden al modelo hegemónico y son estigmatizadas por quienes los rechazan y discriminan.

En el bloque temático Cuerpos, autonomía y feminismos se plantean dos temas fundamentales para el ejercicio de los derechos humanos de las mujeres: el aborto y el ocio festivo. Iris González Cortez nos ofrece un texto para reflexionar sobre el derecho a decidir en la defensa del aborto y en la lucha por la desestigmatización del trabajo sexual, donde discurre sobre algunas reflexiones en torno a cómo algunas feministas eran capaces de defender el aborto como una forma de las mujeres a decidir sobre su propio cuerpo y al mismo tiempo criminalizar el ejercicio del trabajo sexual. En este sentido, se pregunta si es posible abordar el trabajo sexual desde algunos de los argumentos o puntos centrales en la defensa y debate del aborto y cuáles de estos puntos y argumentos atraviesan ambos temas. Por su parte, el texto construido por Ángela Rivera Martínez y Victoria López Rosete reflexiona, desde matrices disciplinares distintas, sobre las prácticas corporales y su mutua implicación al trazar líneas acerca de cómo vemos y cómo nos situamos en sociedades profundamente asimétricas como las contemporáneas, y plantean la posibilidad de crear y retomar territorios que se sostienen en un "estar juntas", explican las autoras, a partir de prácticas corporales como el baile y el ocio festivo, inscrito en una problemática de habitar un "afuera" no pensado para las mujeres y menos para las lesbianas.

En el bloque llamado Identidades trans presentamos textos realizados por Siobhan Guerrero, Leah Muñoz, María Fernanda López López y Andrea Angulo Menasse. "Ontopolíticas del cuerpo trans: controversia, historia e identidad" es un texto a dos voces, donde Siobhan Guerrero y Leah Muñoz proponen un objetivo tripartito: la construcción de un marco teórico para pensar 
la historia del cuerpo trans y lo que las autoras llaman la política ontológica de dicho cuerpo. En segundo lugar esbozan una historia política de las corporalidades trans y de las condiciones que las han ido transformando, alejándolas de un discurso médico y acercándolas a un discurso centrado en la autonomía, el derecho y la identificación, para finalmente examinar cómo las controversias contemporáneas en torno al cuerpo trans implican una nueva transformación de cómo, en general, habitamos y pensamos los cuerpos, seamos sujetos cis o trans.

El texto de María Fernanda López López presenta un estudio monográfico sobre patologización y despatologización de las identidades trans en la Ciudad de México, donde, a partir de un análisis discursivo en la Campaña Internacional por la Despatologización, explora la inserción de estos discursos en las leyes y la atención médica de la Clínica Especializada Condesa, así como en la segunda reforma al Código Civil de 2008. Finalmente, el texto de Andrea Angulo Menasse analiza la película Quebranto, que aborda la historia de Fernando García antes, durante y después de que decidiera transitar hacia la identidad femenina conocida como "Coral Bonelli". Andrea nos invita a reflexionar sobre cómo la identidad de hombre que le fue impuesta a Fernando se interrumpe para que otra, diversa y coherente con su vivencia subjetiva, vea la luz.

Reconocer el pasado: el lugar de la adultez en un mundo diverso acoge el texto de Karla Margarita Ortiz Antuna sobre las personas adultas mayores y los retos que implica para nuestro país la firma de la Convención Interamericana sobre la Protección de las Personas Mayores, donde desarrolla la importancia de este instrumento para fomentar la no discriminación por edad, garantizar oportunidades de trabajo y educación, reconocer su derecho a la salud, a la alimentación y a tener una familia, así como abrir los espacios para vivir en sociedad y darles certeza jurídica para fomentar un trato digno y respetuoso a este grupo social.

Finalmente, en el apartado Grupos indígenas y medios de comunicación autónomos, Viviana Pineda Partida analiza las políticas de 
exclusión y la criminalización de la que son objeto por el uso de los medios de comunicación en nuestro país a partir de analizar el dispositivo de dominación que mantiene el despojo y explotación sistemáticos de los pueblos originarios y las contradicciones legales que reconocen un Estado pluricultural que no permite el reconocimiento y el ejercicio efectivo de los derechos de los pueblos indígenas en México.

Para el Laboratorio Nacional Diversidades UNAM-Conacyt abrir espacios para la reflexión y la interacción de todas las diferencias, para aprender a valorarlas y a comprender las propias, implica abonar para el desarrollo de habilidades sociales que - explica Nussbaum — "son igualmente cruciales para la salud interna de cualquier democracia y para la creación cultural mundial decente, capaz de abordar de manera constructiva los problemas más apremiantes del mundo". ${ }^{4}$ Sirva este pequeño esfuerzo colaborativo para entablar más diálogos diversos para imaginarnos más mundos posibles.

Lucía RAPHAEL DE LA MADRID

Antonio GÓmEz CínTORA

Ciudad Universitaria, noviembre de 2017

$4 \quad$ Ibidem, pp. 3 y 4. 
Esta obra forma parte del acervo de la Biblioteca Jurídica Virtual del Instituto de Investigaciones Jurídicas de la UNAM www.juridicas.unam. $\mathrm{mx}$ https://biblio.juridicas.unam.mx/bjv

Libro completo en: https://goo.gl/sHxaH7

\section{DE LA FAMILIA TRADICIONAL A LA DIVERSIDAD FAMILIAR}




\title{
DIVERSIDADES FAMILIARES: ESPACIOS DE GONSTRUGGIÓN DE APERTURA, JUSTICIA Y EQUIDAD
}

\section{Adriana Segovia URbano}

\begin{abstract}
Sumario: I. Diversidades familiares, desde dónde. II. ¿Por qué trabajar en las diversidades familiares? III. La diversidad familiar en Salvador Minuchin. IV. Resistencias a la cultura dominante desde la diversidad familiar: Michael White. V. Concepciones sobre diversidad y su aplicación a la diversidad familiar. VI. Los temas que la diversidad familiar deja sobre la mesa.

VII. Bibliografia.
\end{abstract}

\section{DIVERSIDADES FAMILIARES, DESDE DÓNDE}

Estudié sociología porque quería comprender los comportamientos humanos explicados desde lo social, camino que cumplió su cometido; me quedaba pendiente la inquietud de trabajar directamente con la gente, por lo que estudié y he ejercido desde hace más de veinte años la terapia familiar. Mi camino personal y los contextos clínicos y académicos en los que me he movido me han permitido entrenarme en mirar de lo individual a lo social y de regreso, siendo las familias espacios privilegiados para mirar y experimentar una especie de cinta de Moebius que expresa todos estos niveles en un continuo individual-social.

Afortunadamente, mi entrenamiento incluyó una sensibilidad a la diversidad familiar que con el tiempo se fue expandiendo gracias no sólo a los principios teóricos y clínicos de la forma- 
ción, sino a las transformaciones sociales y jurídicas que fueron ocurriendo especialmente en los últimos diez años a nivel local y federal: legalización de matrimonios entre personas del mismo sexo, interrupción legal del embarazo y leyes contra la violencia hacia las mujeres.

Por lo anterior, este texto pretende ser una primera y breve sistematización de lo aprendido teórica y clínicamente en la experiencia del trabajo con familias, enriquecida ahora por mi pertenencia al Laboratorio Nacional Diversidades como un espacio que permite un diálogo entre disciplinas y experiencias que sin duda han estimulado aún más mis reflexiones sobre las familias, ahora con el objetivo puesto en entender las diversidades familiares conceptualmente, descubrir lo que aporta la experiencia en el trabajo clínico en este tema y pensar en lineamientos para el trabajo con las diversidades en general, con la diversidad familiar, así como en la construcción de una cultura basada en la apertura, el respeto y la equidad. Esbozaré entonces por qué es importante trabajar (visibilizar, incidir) en las diversidades familiares; cómo lo han hecho dos autores clave de la terapia familiar (Minuchin y White); cómo relacionar estas aportaciones con algunas reflexiones sobre las diversidades desde otros campos, y cuáles son los temas que habrá que desarrollar particularmente sobre la diversidad familiar.

\section{II. ¿POR QUÉ TRABAJAR EN LAS DIVERSIDADES FAMILIARES?}

La familia es, al igual que el género y la raza, una construcción social e histórica. En el Estado moderno, y regida por exigencias del mercado, la familia se definió como una unidad formada por cónyuges e hijos, relacionados por parentesco, con un modelo afectivizado de relaciones que tiene como base una vida familiar nuclear. Este modelo se volvió "universal", con valores y simbolismos tales como la elección romántica de la pareja y la impor- 
tancia sobre la crianza de los hijos depositada en la mujer-madre como su tarea central. Se construyó así un modelo tradicional de familia: por encima de todo, un vínculo heterosexual dirigido a los fines de reproducción, con autoridad predominante del padre sobre todos los miembros de la familia (patrón patriarcal), con roles estereotipados, rígidos y divididos polarizadamente entre hombres y mujeres, básicamente entre proveedores económicos, los primeros, y proveedoras afectivas, las segundas. ${ }^{1}$

Como todo modelo "universal", se volvió normativo, formando parte de estructuras y símbolos propios de una cultura dominante que tiende a dictar no lo que las familias son, sino "lo que la familia debe ser". Y como tal, se volvió restrictivo de las múltiples posibilidades de ser familia y de ser humano.

Hacia adentro de la familia el modelo lleva en sí mismo un acomodo jerárquico y desigual del poder, así como de las funciones y las posibilidades de desarrollo de sus miembros. Hacia afuera se construye como un modelo de "normalidad", "felicidad" y "salud" digno de ser alcanzado. Mientras más rígido y estereotipado sea el modelo, más perfecto parece, por lo que todas las estructuras sociales y sus dispositivos culturales se aprestan a ensalzarlo y a sancionar a quienes se alejan de este modelo.

Por otro lado, la realidad da cuenta de que el modelo dominante de familia no es tal. Por hablar sólo de un indicador, los hogares encabezados por una "jefa de familia" son una tercera parte de los hogares mexicanos. ${ }^{2}$ Es apenas que los estudios demográficos están registrando estas diversidades, porque la propia concepción de tales estudios ha partido de un modelo dominante de familia. El solo concepto "jefe de familia" da cuenta del modelo familiar heteronormativo y patriarcal. Y a pesar de que las realidades familiares son diversas, el imaginario social sigue perpetuando al modelo dominante, mismo que lo convierte en un dispositivo discriminatorio:

1 Monroy, Lilia, Familias, identidades y diversidades desde la perspectiva de género. Notas, México, ILEF, 2010.

2 Encuesta intercensal 2015, México, INEGI, 2015. 
...la discriminación es una relación en la que un grupo con capacidad de ejercer alguna o varias formas de dominio (económico, político, cultural) minusvalora o repele a otro grupo, colocándolo en una situación de desigualdad u opresión. Para hacerlo, se toma como punto de partida algún rasgo característico del grupo excluido, y con base en él se construyen estereotipos prejuiciados de inferioridad, inmoralidad o peligrosidad. En este sentido, pueden considerarse formas de discriminación la xenofobia, el racismo, la misoginia, la homofobia, el clasismo, que se basan en el origen étnico, el color de piel, el género, las preferencias sexuales o la condición social. ${ }^{3}$

Es decir, así como en la anterior definición de discriminación, un grupo dominante excluye al otro, un modelo dominante de cualquier característica (étnico, religión, género, funcionalidad, corporal, económico, de estructura, como en el caso de las familias) tiende a excluir, invisibilizar, estigmatizar y discriminar al diferente. La discriminación provoca el sufrimiento de quienes no pertenecen a los modelos dominantes, los priva de legitimidad y los excluye de las condiciones para su desarrollo económico, social y cultural, por lo que esto se convierte en un círculo vicioso. Así como la igualdad, la no discriminación y los derechos sociales se convierten en una vinculación virtuosa, como explican Rodrigo Gutiérrez y Pedro Salazar, ${ }^{4}$ es indispensable pensar mecanismos que visibilicen e incidan en la diversidad familiar y combatan la discriminación dirigida a estas familias, con el fin de superar los efectos negativos de ésta en las mismas, así como desplegar su riqueza para la sociedad en general.

\section{LA DIVERSIDAD FAMILIAR EN SALVADOR MINUCHIN}

Salvador Minuchin (San Salvador, Entre Ríos, Argentina, 19212017) es el creador de la corriente estructural dentro de la terapia

3 Gutiérrez, Rodrigo y Salazar, Pedro, Igualdad, no discriminación y derechos sociales. Una vinculación virtuosa, México, Conapred, 2011, p. 43.

4 Idem. 
familiar sistémica. Desarrolló la mayor parte de su trabajo en Estados Unidos, por lo que a pesar de su pertenencia a tantas intersecciones de la cultura dominante, fue particularmente sensible a las minorías migrantes, de clase y de cultura. Fue formador de generaciones de feministas como las terapeutas del Instituto Ackerman (Nueva York), quienes en la década de los años ochenta pensaron sus modelos al mismo tiempo honrando y divergiendo de su maestro. Su modelo estructural, con muchos riesgos de parecer normativo - nunca lo fue-, evolucionó en un modelo incluyente de la diversidad familiar.

En uno de sus primeros textos, Families of the Slums, ${ }^{5}$ reflexiona sobre el trabajo que realiza con familias en extrema pobreza de los barrios marginales de Nueva York. En una época y contexto donde la pobreza era motivo de estigmatización de las víctimas de la misma, Minuchin se pregunta qué hace que no todas las familias que viven en estas condiciones estén condenadas al mismo círculo vicioso de su marginación, y se propone así reconocer y trabajar con sus recursos particulares. En este contexto crea el concepto de "hijo parental"; un hijo a cargo de los hermanos menores en familias donde los adultos están ausentes por trabajo o abandono, y que para los lentes prejuiciados de psicólogos, trabajadores sociales o maestros podría ser un indicador de "disfunción" e irremediable fracaso. Minuchin contextualiza al hijo parental, entendiéndolo como un emergente de una situación de precariedad en el que la familia se organiza para cumplir las funciones ejecutivas que se requieren; lo reconoce como un recurso valioso de estas familias y trabaja terapéuticamente para que este hijo logre tener un papel flexible que le permita descargarse cuando sea posible, pero claro, para no caer en situaciones atrapantes.

En un texto de treinta años después, Minuchin define así a la terapia familiar:

5 Minuchin, Salvador et al., Families of the Slums: An Exploration of Their Structure and Treatment, Nueva York, Basic Books, 1967. 
....se puede concebir como un enfoque de tratamiento de los problemas humanos por medio de la reunión de los miembros de la familia, para ayudarlos a elaborar los conflictos en su origen. Pero es también un nuevo enfoque tendiente a comprender la conducta humana como fundamentalmente conformada por su contexto social. ${ }^{6}$

Contexto social es un concepto clave para Minuchin y para la comprensión de la diversidad familiar. Nada puede ser comprendido fuera de su contexto porque se cierne la amenaza, en salud mental, de patologizar situaciones que se comparan con modelos normativos y dominantes. La terapia familiar, dice Minuchin en este mismo texto, desafió la idea de que el individuo era el centro del universo psicológico y puso contexto a conceptos patologizantes de realidades diversas: "madres sobreprotectoras", "madres esquizofrenizantes", "parectomía" (extirpar padres a hijos con problemas). Sin omitir que Minuchin está dialogando en su momento con críticos de "la familia como represora" (Laing y Cooper), su exitoso trabajo clínico con innumerables familias y sus aportaciones teóricas a la comprensión social de las mismas se resumen en estos conceptos que, en mi opinión, inciden en la comprensión y trabajo con la diversidad familiar: contexto, flexibilidad y pertenencia.

\section{RESISTENCIAS A LA GULTURA DOMINANTE DESDE LA DIVERSIDAD FAMILIAR: MICHAEL WHITE}

Michael White (Adelaida, Australia, 1948-2008) es el creador de la corriente narrativa dentro de la terapia familiar. Las bases filosóficas de su trabajo se encuentran en el estudio de M. Foucault y J. Derrida. Del primero retoma el concepto de "poder moderno", aquel que ha pasado de ser una dominación de un externo a ser

6 Minuchin, Salvador y Nichols, Michael P., La recuperación de la familia. Relatos de esperanza y renovación, Barcelona, Paidós, 1994, p. 47. 
un dominio internalizado por el propio sujeto. Los instrumentos de vigilancia y castigo son ejercidos por cada individuo gracias a que una cultura dominante los ha normalizado y el sujeto los ha internalizado. Foucault señala las resistencias individuales y sociales que se pueden hacer a ese poder. De Derrida toma la idea de construcción-deconstrucción de la realidad.

White considera, siguiendo a Foucault, que existe una cultura dominante que tiende a normalizar y a fijar criterios de verdad a partir de ésta. Esta cultura dominante tiende a aplastar las diferencias, las conductas o características humanas que no se ajustan a ésta, y es a partir de ese "desajuste" a tal cultura que surgen el sufrimiento y los problemas existenciales de las personas, quienes arman narrativas sobre su vida a manera de fracaso personal (son sus propias historias dominantes), que pueden leerse también como resistencias a esa cultura dominante. White propone trabajar descubriendo, señalando, deconstruyendo esas historias dominantes, reconociéndolas como producto de esa dominación y al mismo tiempo como resistencia a la misma. Busca las excepciones en las historias dominantes para deconstruir tales historias y re-narrar la vida de las personas a partir de historias alternativas a la dominante, lo que llama las historias preferidas. En este sentido, White considera el espacio terapéutico como un espacio donde se hace política en la medida que se propone la resistencia a la cultura dominante.

Para White, los terapeutas deben contribuir a entender los problemas de las personas en términos de contextos más amplios de sus vidas: la familia, las instituciones, la sociedad, la cultura local. La terapia familiar rechaza las nociones esencialistas en la formación de la identidad. Pone énfasis en la permanente renegociación de las identidades de las personas gracias a su participación e interacciones en sus familias o en las comunidades a las que pertenecen. ${ }^{7}$ Este entendimiento del contexto es la primera clave para el entendimiento de las diversidades familiares. La

7 White, Michael, "Diversity and Narrative Therapy", Reflections on Narrative Practice, Adelaida, Dulwich Centre Publications, 2000, p. 90. 
segunda es el trabajo con las personas a partir de sus historias preferidas, deconstruyéndolas desde su inserción en la cultura dominante.

Un concepto más de sus aportaciones subraya que las prácticas de los terapeutas deben contribuir a reconocer los conocimientos locales (insider) de las personas en sus familias y sus comunidades y en el desarrollo de habilidades para vincularse con la gente en sus esfuerzos por poner esos conocimientos locales en la más amplia expresión, no sólo evaluando los problemas por los que buscan terapia, sino transformando la cultura local. ${ }^{8}$

Para White, los terapeutas pueden reproducir la cultura dominante en el caso de las diversidades; por ejemplo, es muy probable que terapeutas y otros servidores de la salud y la educación tiendan a mirar a la diversidad desde el marco de la "familia normal", y éste es un peligro de iatrogenia y discriminación brutal, porque proviene de discursos profesionales que se ubican desde "la verdad", y es por eso que reflexiona sobre una serie de dispositivos para estar conscientes de ese hecho:

En realidad, los terapeutas son confrontados con el hecho de que la presunción de neutralidad no es neutral en sus efectos y que son las mismas condiciones establecidas por esta ilusión de neutralidad lo que les permite reproducir las estructuras de privilegio y las relaciones de poder de la cultura dominante. Son estas estructuras de privilegio y relaciones de dominación las que marginan a las personas que piden ayuda terapéutica, mantienen jerarquías de conocimiento, descalifican modos de vida y pensamientos alternativos, mantienen el monopolio de poder del terapeuta y hacen invisible la posición del terapeuta en los mundos del género, la cultura, la etnicidad, la preferencia sexual, la clase, etcétera.

\section{Así propone:}

$\mathrm{Al}$ deconstruir los conceptos del conocimiento experto y observación neutral, los terapeutas se ven libres de reconocer y aceptar la

8 Idem. 
responsabilidad ética que tienen por los efectos reales de su trabajo: por los efectos reales de su trabajo en la constitución de las vidas de las personas que los consultan. ${ }^{9}$

Entonces, la tercera clave del entendimiento y trabajo de White con las diversidades es la conciencia de las posiciones de privilegio para colocarse en un lugar co-deconstructor de la cultura dominante, poniendo en el centro los saberes y preferencias de los consultantes, reconociendo el sistema político completo de dominación y resistencias.

\section{CONCEPCIONES SOBRE DIVERSIDAD Y SU APLICACIÓN A LA DIVERSIDAD FAMILIAR}

Como señalábamos antes, en el texto de Rodrigo Gutiérrez y Pedro Salazar ${ }^{10}$ se establece la relación entre derechos sociales y diversidad, los primeros como la concreción legal de reivindicaciones sociales que, interrelacionadas, brindan las condiciones que permiten a las personas llevar a cabo un proyecto de vida propio, autónomo y digno. Dentro de estos derechos se encuentra el derecho a la no discriminación por motivo de alguna diferencia de pensamiento, física, religiosa, económica, sexo-genérica. La discriminación produce exclusión de bienes, intereses o libertades; de ahí la importancia de la inclusión de las diversidades en la construcción de una sociedad verdaderamente democrática. De este modo, el reconocimiento de las diversidades se vincula a principios de igualdad, inclusión, democracia, libertad.

Siguiendo esta línea que vincula derechos, desarrollo y diversidad, la filósofa norteamericana Martha Nussbaum, en su propuesta sobre el desarrollo humano con enfoque en las capacidades, que consiste en un conjunto de oportunidades para ele-

9 White, Michael, El enfoque narrativo en la experiencia de los terapeutas, Barcelona, Gedisa, 1997, p. 159.

10 Gutiérrez, Rodrigo y Salazar, Pedro, op. cit. 
gir y actuar (un enfoque, como dice ella, "pariente cercano de los derechos humanos"), reflexiona sobre la diversidad cultural como un elemento a considerar en este desarrollo. ${ }^{11}$ Este enfoque sugiere, por ejemplo, incorporar la tradición cultural, pero sólo como un referente con el cual dialogar. "El enfoque de las capacidades sugiere que las evaluemos usando la idea de la dignidad humana para todas las personas como guía". ${ }^{12} \mathrm{El}$ respeto por la diversidad, dice Nussbaum, incluye una estrategia de aconfesionalidad (laicidad), para no tocar temas altamente divisivos. El desarrollo de capacidades implica un necesario pluralismo. "La libertad de expresión, la libertad de asociación, la libertad de conciencia, y la accesibilidad y las oportunidades políticas son aspectos cruciales para una sociedad que se proponga proteger el pluralismo cultural y religioso". ${ }^{13}$ He aquí la importante diferencia entre sólo "respetar las tradiciones locales", aludiendo a un cierto relativismo cultural, porque muchas de éstas no respetan las libertades de creencias ni otros elementos del pluralismo, y agrego, ni de otras libertades y derechos. Es prioridad - afirma la filósofa - que la sociedad se posicione a propósito de ciertos valores globales dirigidos a proteger la libertad de elección de sus ciudadanos y ciudadanas.

Retomo otros conceptos de Nussbaum en el abordaje de las diversidades: lo que llama la "mirada mental" y el ejercicio de la "imaginación empática", ${ }^{14}$ conceptos desarrollados en su libro $L a$ nueva intolerancia religiosa, donde reflexiona sobre un ejercicio para la inclusión de las diversidades que tiene que ver con la empatía y que ésta se desarrolla a través del ejercicio de esa mirada mental, haciendo un esfuerzo de imaginación empática, mirar a los otros con curiosidad, indagación y receptividad, "la voluntad de salir

11 Nussbaum, Martha C., Crear capacidades. Propuesta para el desarrollo humano, Barcelona, Paidós, 2012, p. 125.

12 Ibidem, p. 131.

13 Ibidem, p. 135.

14 Nussbaum, Martha C., La nueva intolerancia religiosa. Cómo superar la política del miedo en una época de inseguridad, Barcelona, Paidós, 2013, pp. 175-226. 
de uno mismo y entrar en otro mundo", como una manera de desarrollar un auténtico respeto, al que no se llega sólo con buenos principios. Para mirar a los otros como personas que tienen derecho a perseguir sus metas tanto como yo las mías.

Por último, Avtar Brah, en su reflexión sobre la diversidad dentro de su discusión sobre un feminismo negro y un feminismo blanco, que finalmente es una discusión sobre diferencias opresoras (y las que no lo son), propone lo siguiente respecto a la acción: “...si la práctica produce poder, entonces es también la práctica el medio para desafiar a las prácticas opresoras de poder. De hecho, ésta es la implicación de la perspectiva foucaultiana de que el discurso es práctica". ${ }^{15}$

Concluyo entonces, con base en las ideas aquí esbozadas, en primer lugar, la importancia de reconocer a las diversidades, porque hacerlo está en relación directa con ideales, conceptos y valores deseables como: democracia, sensibilidad al género, derechos humanos, desarrollo, bienestar, justicia e igualdad. En segundo lugar, que las vías para alcanzar este reconocimiento pasan por las políticas públicas, el activismo, la academia, la legislación, la educación y por acciones de incidencia social y cultural que las visibilicen.

En el caso de las diversidades familiares, algunas de estas acciones han pasado, por ejemplo, por la defensa y legalización de los matrimonios igualitarios y su muy incipiente visibilización y normalización en la cultura. Sin embargo, la complejidad de la diversidad familiar requiere de acciones más intensas y en muchos ámbitos. Retomando de forma general a los autores y autoras citados, propongo seguir desarrollando y difundiendo la idea del derecho a la no discriminación, retomar las ideas de ubicar los contextos de las familias, reconocer las historias oprimidas por la cultura dominante y trabajar con la mirada mental y la imaginación empática. Estos conceptos pueden aplicar al ámbito

15 Brah, Avtar, "Diferencia, diversidad y diferenciación", Otras inapropiables. Feminismos desde las fronteras, Madrid, Traficantes de Sueños, 2004, p. 131. 
de la terapia familiar, que es mi campo y "laboratorio", creado con colegas, de reflexión social, pero son miradas que pueden aplicarse a otros ámbitos: académicos, de medios de comunicación y de incidencia cultural, como los ejemplos que da Martha Nussbaum respecto a la literatura como medio que invita a la imaginación empática. Considero que las expresiones culturales, la educación y el contenido de los medios de comunicación también tienen que trabajar en esa dirección para visibilizar e invitar a la comprensión y respeto de la diversidad familiar.

\section{LOS TEMAS QUE LA DIVERSIDAD FAMILIAR DEJA SOBRE LA MESA}

Lo que no querría hacer es crear tipologías de "nuevos tipos de familia", ${ }^{16}$ quisiera más bien apuntar algunas situaciones que se apartan del modelo dominante de familia, heteronormativo y constituido por papá, mamá, hijos, de preferencia el mayor hombre, y que provocan en algunas familias diversas un grado de malestar, por no pertenecer al modelo dominante (autodiscriminación, aunque sea inconsciente), y en ocasiones discriminación de los otros.

\section{Familias ensambladas o reconstituidas}

Aunque son producto de un derecho que tiene más de cien años, el divorcio, el estigma de las personas divorciadas o los hijos e hijas del divorcio pervive en ciertos sectores de la sociedad y es asociado a ideas patologizantes como "disfuncionalidad". El crecimiento de las tasas de divorcio ha dado lugar a complejidades de convivencia para los hijos en diferentes casas y con

16 “7 tipos de familias en México que prevalecerán”, declaración de Heriberto López Romo, académico de la Universidad Iberoamericana, Sin Embargo, México, 24 de mayo de 2014. 
diferentes figuras parentales que pueden llegar a tener arreglos perfectamente saludables si estas convivencias se normalizan en la cultura.

\section{Parentalidades de la diversidad sexo-genérica}

La reciente legalización de los matrimonios igualitarios en la Ciudad de México (2009) y la declaración por parte de la Suprema Corte de Justicia de la inconstitucionalidad de su prohibición en el país (2015) contribuyeron a legitimar y visibilizar un arreglo familiar que se daba de facto hace mucho tiempo. Son, pues, muy recientes y escasos los estudios sobre el funcionamiento de estas familias y todos han demostrado que su principal problema no parte de su interior, sino de la discriminación exterior. Por el contrario, se ha encontrado que en las familias homoparentales los hijos e hijas tienden a asumir menos estereotipos de género en juegos y tareas, así como a tener una mayor apertura a la diversidad en general. ${ }^{17}$ A estos estudios habrá que agregar las demás diversidades sexo-genéricas.

\section{Mujeres solas y/o sin hïos}

Por un lado, existen hombres y mujeres, solteros o en pareja o con otros arreglos de relación, que han optado por no tener hijos. Sin embargo, en la construcción de la imagen de la mujer en una cultura dominante, que tiende a las concepciones esencialistas y naturalistas, el no tener hijos se convierte en un estigma contra el que hay que luchar. En este caso insistiré, como casi en todos, que la decisión personal se queda muy sola si no hay una cultura que resista al modelo dominante y normalice los mu-

17 Angulo, Andrea, "Familias homoparentales: de los aportes más importantes en el campo de la psicología", Familias homoparentales, México, Letra S, AMCI, 2015. 
chos modos de ser mujer, aun sin hijos, y es esto lo que tiene que construirse. Porque de lo contrario hay estigma, discriminación y sufrimiento.

\section{El mito de la falta de la figura masculina}

Por otro lado, como se señaló en el segundo apartado de este trabajo, hay casi un tercio de los hogares en este país encabezados por mujeres, y con todo lo funcionales que pueden ser, el estigma que se cierne en muchas familias es una narrativa de carencia: la falta del padre. Y éste es un mito popular alimentado por discursos profesionales que afirman que los hijos varones necesitan a un hombre para hacerse hombres. Cuando avancemos en la deconstrucción de estereotipos de género será más evidente que la crianza debe dirigirse a criar personas de bien, no a "hacer mujeres o a hacer hombres".

\section{Los desafios de las tecnologías de la reproducción}

Los avances en la reproducción asistida presentan desafíos bioéticos y legales, ${ }^{18}$ al tiempo que abren una gama de posibilidades, porque así como los anticonceptivos rompieron el mito de que el sexo era sólo para la reproducción, la reproducción asistida rompe el mito de que se necesita una pareja heterosexual para la reproducción. Por el momento son más las mujeres solas o parejas de mujeres que recurren a estos métodos, construyendo así nuevos modelos de maternidad, especialmente el de las madres solteras por elección, que construye narrativas de empode-

18 En los servicios de reproducción asistida, la legislación española permite que cualquier mujer mayor de 18 años, independientemente de su estado civil y orientación sexual, acceda a los servicios de reproducción asistida, mientras que legislaciones como la italiana, francesa, portuguesa o austriaca no lo permiten más que a parejas heterosexuales. Casado, María y Royes, Albert, Sobre bioética y género, Navarra, Civitas, 2012. 
Esta obra forma parte del acervo de la Biblioteca Jurídica Virtual del Instituto de Investigaciones Jurídicas de la UNAM

ramiento por su capacidad económica, de madurez, de elección y de autonomía para hacerlo. ${ }^{19}$

\section{Diversidad y discriminación al interior de las familias}

Queda también por reflexionar cómo la cultura dominante reproduce al interior de las familias discriminación y violencia, tema muy importante a trabajar también a ese nivel microsocial y cultural por los medios y con los conceptos que he señalado. En el apartado $\mathrm{V}$ señalé la importancia de trabajar en la visibilización y normalización (mirada normalizante y no exotizante) de las diversidades familiares, por los valores deseables que conlleva, pero también hay que señalar que la vida en la diversidad, que implica resistencias al modelo dominante, como se apuntó en este último apartado, también construye en su práctica, apertura, equidad, justicia y democracia en la sociedad.

\section{BIBLIOGRAFÍA}

"7 tipos de familias en México que prevalecerán", Sin Embargo, México, 24 de mayo de 2014.

Angulo Menasse, Andrea, "Familias homoparentales: de los aportes más importantes en el campo de la psicología", Familias homoparentales, México, Letra S, AMCI, 2015.

BRAH, Avtar, "Diferencia, diversidad y diferenciación", Otras inapropiables. Feminismos desde las fronteras, Madrid, Traficantes de Sueños, 2004.

CASAdO, María y ROYES, Albert, Sobre bioética y género, Navarra, Civitas, 2012.

Encuesta intercensal 2015, México, INEGI, 2015.

19 González, María-Mar et al., "Maternidad a solas por elección: primera aproximación", Anuario de Psicología, Barcelona, vol. 39, núm. 1, 2008. 
GonzÁLEz, María-Mar et al., "Maternidad a solas por elección: primera aproximación”, Anuario de Psicología, Barcelona, vol. 39, núm. 1, 2008.

GutiérRez, Rodrigo y SALAZAR, Pedro, Igualdad, no discriminación y derechos sociales. Una vinculación virtuosa, México, Conapred, 2011.

Minuchin, Salvador et al., Families of the Slums: An Exploration of Their Structure and Treatment, Nueva York, Basic Books, 1967.

Minuchin, Salvador y NichOLS, Michael P., La recuperación de la familia. Relatos de esperanza y renovación, Barcelona, Paidós, 1994.

MONROY, Lilia, Familias, identidades y diversidades desde la perspectiva de género. Notas, México, ILEF, 2010.

Nussbaum, Martha C., Crear capacidades. Propuesta para el desarrollo humano, Barcelona, Paidós, 2012.

Nussbaum, Martha C., La nueva intolerancia religiosa. Cómo superar la política del miedo en una época de inseguridad, Barcelona, Paidós, 2013.

White, Michael, "Diversity and Narrative Therapy", Reflections on Narrative Practice, Adelaida, Dulwich Centre Publications, 2000.

WHITE, Michael, El enfoque narrativo en la experiencia de los terapeutas, Barcelona, Gedisa, 1997. 


\title{
REFLEXIONES SOBRE EL DERECHO DE ADOPGIÓN Y LAS FAMILIAS HOMOPARENTALES
}

\author{
Lucía RAPHAEL DE LA MADRID
}

Creo que es importante comenzar por comprender que vivimos en un país en el que el mosaico riquísimo de la diversidad define o debe definir la inmensa riqueza de la realidad humana que nos conforma, que las grandes civilizaciones lograron niveles de desarrollo extraordinarios porque supieron valorar y aprovechar esta riqueza y las posibilidades que el respeto de la diferencia, el intercambio cultural, social, humano y comercial, y esta posibilidad de cohabitar el mismo espacio desde la tolerancia y el respeto de las alteridades, dieron origen a civilizaciones como la persa, la fenicia, la romana, y que aspiro a que las y los mexicanos tengamos la capacidad de valorar la manera en que todas las diversidades, sean étnicas, lingüísticas, fenotípicas, sexo-genéricas, así como culturales, nos atraviesan, constituyéndose en nuestro valor en tanto seres humanos. Mientras no estemos dispuestxs a comprender esta riqueza y a renunciar a la necesidad de construir en "el otro" / "la otra" a un enemigo que nos sirva para encerrarnos en nosotrxs mismxs, para poder echarle la culpa de nuestros propios problemas, no lograremos evolucionar ni crecer como nación.

Por el contrario, los avances en materia de defensa de las diversidades, que en mayor o menor grado hemos ido alcanzando a pesar de una tendencia regresiva hacia el endurecimiento de posturas discriminatorias, en el papel es loable, pero se refleja poco 
en la vida de las personas que pertenecen a las diversidades; además, es importante reconocer que no ha ocurrido de una manera homogénea ni igualitaria, y que esto ha generado, en temas como las diversidades sexo-genéricas y sus derechos y aspiraciones, estatus de ciudadanos de primera o de segunda, violentando profundamente nuestra Constitución y las leyes que ésta sustenta. Es importante subrayar que es gracias a los movimientos de estas diversidades, el activismo, los movimientos sociales particularmente desde finales de los años sesenta y principios de los setenta, que su incidencia en convenciones internacionales ha podido permear hacia las leyes nacionales, y que son estos procesos los que han permitido que las cosas evolucionen. Es cierto que algunos temas de las diversidades en materia jurídica han tenido avances, y que considerando el carácter conservador de una gran mayoría de la población y particularmente de un alto porcentaje de agentes del quehacer político, los avances son considerables, aunque falte todo por hacer, ya que la apuesta es que el solo hecho de ser personas implique tener acceso a todos los derechos. Pero es de los avances en los temas de matrimonio igualitario y adopción por parejas del mismo sexo que reflexionaré en este trabajo.

La Ciudad de México ha sido particularmente vanguardista en estos temas y ha abierto la puerta para que en diez estados de la República Mexicana se realicen en mayor o menor medida cambios sustanciales, aunque cabe aclarar que éstos han tenido lugar apenas en este milenio.

El tema del matrimonio igualitario y la adopción por parte de parejas homosexuales lo he venido siguiendo de manera más cercana desde 2010, cuando el entonces PUEG (ahora CIEG) me hizo el honor de invitarme a participar en su representación, al interior de un equipo interdisciplinario coordinado por José Luis Caballero, para la formulación de un amicus curiae que diera elementos de argumentación al ministro Sergio Armando Valls Hernández frente a la demanda que interpuso el entonces procurador general de la República, Eduardo Tomás Medina Mora, y el también entonces presidente de la Comision Nacional de 
Derechos Humanos, José Luis Soberanes, quienes se manifestaron abiertamente contra la legalización de dichos derechos para las diversidades sexo-génericas. Demanda que, como todos sabemos, no prosperó. Y legalización que, como también todos sabemos, sigue, a diez años de haber sido lograda, constreñida a la isla de derecho y de libertades en que se ha constituido la Ciudad de México, y a otros cuantos estados como Chihuahua, Campeche, Coahuila, Colima, Jalisco, Michoacán, Morelos, Sonora, Nayarit y Quintana Roo y, gracias a la SCJN, en Puebla, recientemente, sin necesitar de amparo, como se hacía anteriormente y se hace en el resto de los estados contrarios a esta apertura. El solo hecho de necesitar de un amparo para ejercer un derecho que corresponde a todx ciudadanx hace sospechosa la capacidad democrática y sobre todo el respeto a los principios de igualdad, libertad y el principio de laicidad de nuestros gobernantes, de nuestros legisladores y de nuestros funcionarios; la cultura tradicionalista y conservadora sigue revolviendo a la Iglesia con el Estado y buscando meterse en la vida de las personas que no pertenecen a sus credos y morales, sin entender que están hechas precisamente para que ellxs puedan ejercer en su propia vida una libertad de creencias, elecciones y pensamiento, acorde a sus propios ideales de vida buena, con los mismos parámetros de respeto hacia los de las personas que pertenecen a otras diferencias cuya validez es la misma que la suya. Desgraciadamente en México, a lo largo del territorio e incluso dentro de los estados mencionados, se endurece de manera exponencial una fuerte postura xenófoba, homófoba y discriminatoria que hace que los agentes de la justicia mismos hagan estos cambios legales, en todos sus niveles, de difícil cumplimiento, y por otro lado que en los estados en donde no se han logrado reformas en este sentido, las posturas xenófobas se acrecienten. Es por ello que es importante hacer las preguntas adecuadas para intentar una reflexión desde la razón y los principios de derecho, que permitan hacernos entender las diferencias; "la diferencia" como un valor a integrar en nosotrxs mismxs, a promover y a respetar. Más que dar respuestas hechas 
o logradas, creo más en la generación de más preguntas que nos ayuden a pensar el país que queremos construir.

Respecto al tema que nos concierne aquí: el matrimonio igualitario y el derecho de las parejas del mismo sexo a adoptar, las primeras preguntas que me vienen a la mente son: ¿qué es una familia?, ¿cómo se integra?, ¿qué relaciones afectuosas, sexuales, económicas y de parentesco la conforman?

Responder a estas preguntas con una sola respuesta genera, por principio, la exclusión de múltiples tipos de familias que no se apegan al modelo tradicional, unicelular y nuclear, y que pensar en un modelo de familia heteronormativo como única opción supone la no aceptación del carácter del concepto "familia" como institución social, y es que ésta evoluciona o debe evolucionar con las transformaciones graduales que tienen lugar en el desarrollo de las sociedades, siendo siempre el resultado de este desarrollo histórico.

Pienso, como muchos especialistas en el ámbito de la sociología, la antropología y de los derechos humanos mismos, que imponer un modelo único de familia, así como ocurre con el pensamiento, invisibiliza el hecho de que la familia nuclear ha coexistido siempre con otros modelos de familia, los cuales van desde las familias monoparentales hasta las extensas, que incluyen algún abuelo, tío, primo y, particularmente en México, algún ahijado o entenado.

Si algo es un hecho en el siglo XXI es la pervivencia de nuevas formas de entender la unidad familiar, y que "la familia", tal cual como era percibida tradicionalmente, ha cambiado, prueba de ello es la diversificación de términos para referirse a ella: monoparentalidad, coparentalidad, homoparentalidad, tantas palabras nuevas que traducen los recientes cambios de la norma familiar que la heteronormatividad pensaba única. Y como Daniel O’Donnell (de la Oficina en Colombia del Alto Comisionado de las Naciones Unidas para los Derechos Humanos) señala, frente a la ausencia de una definición del término "familia" en el ámbito internacional: 
La razón de la ausencia de definiciones de "familia" en la mayor parte de los instrumentos que reconocen sus derechos parece ser la apuntada por el Comité de Derechos Humanos, a saber: la necesidad de preservar la inherente flexibilidad del concepto que varía en función del contexto sociocultural. ${ }^{1}$

Efectivamente, hoy en día existe una considerable cantidad de relaciones de parentesco que no se ajustan al modelo de la familia nuclear, que dependen de relaciones afectivas, biológicas y no biológicas, y que rebasan los alcances de los conceptos jurídicos actuales y que funcionan con normas que no se han formalizado o que han sido mantenidas en los márgenes. De este modo, las familias homoparentales se inscriben en un grupo de familias, sin que más allá de las semejanzas parciales sea necesario ni posible suponer un denominador común; de esta manera, el sociólogo y especialista francés Eric Fassin propone “...renunciar a sustituir la diferencia de los sexos por otro núcleo duro, para hacer lugar a una nueva realidad en la que quepan todos los modos de ser y hacer familia". ${ }^{2}$

\section{II}

La importancia de una verdadera democracia radica en poder darle a las leyes la objetividad y la coherencia con la realidad del país en donde las leyes rigen. La evolución del derecho, la conformación de los derechos humanos, la aplicación de los principios de igualdad, libertad, diversidad, han sido posibles porque las instituciones y las personas que las conciben lo han hecho desde

1 Derecho internacional de los derechos humanos. Normativa, jurisprudencia y doctrina de los sistemas universal e interamericano, Oficina en Colombia del Alto Comisionado de las Naciones Unidas para los Derechos Humanos, Bogotá, abril de 2004, pp. 824 y ss.

2 Fassin, Eric, Au-delà du PaCS, L'expertise familiale à l'epreuve de l'homosexualité, París, Presses Universitaires de France, 2005, colección Politique aujourd'hui, p. 70 . 
altos conceptos de ética y de la búsqueda de un bien común. En materia de categorías, la misma Constitución mexicana expone la riqueza que representa la diversidad de individuos que forma parte de una misma población, y su texto no excluye a ninguna de estas especificidades como determinaciones para considerar a los individuos que cumplen con sus características como excluidos de la ley. Pero por una razón que no tiene que ver con la ley sino con la subjetividad de quienes la aplican, las categorías que entran en materia de género y de "preferencia sexual" sí sufren de esta exclusión.

Todos nos hemos sentido en algún momento u otro atrapados por las etiquetas, y las categorías o las exigencias que una de estas etiquetas nos impone. Todos hemos pasado por la sensación de aprisionamiento y/o constreñimiento que nuestro "género" o los roles predeterminados que al interior de la sociedad, de la cultura de la "familia", son exigidos. Los estudios de género han mostrado cómo el varón heterosexual mismo, en su rol androcéntrico, está tan condicionado y paga tan caro las exigencias e imposiciones hacia su género, como un transexual o como una lesbiana. El peso de la exigencia de su rol, en el caso del paradigma masculino ("hombre, blanco, católico, alfabetizado, propietario...") es directamente proporcional a la expectativa de su entorno, al conservadurismo de sus posturas, a la necesidad de abrazarse a dioses monolíticos inherentes a su necesidad de poder, de dominación, de privilegio, de prestigio. Aunque su misma jerarquía, en apariencia superior, le haga pensar que tiene todas las de ganar, y es por ese engaño que le es tan difícil cambiar la receta de su visión del mundo por algo más libre para él, como para los otros. Pero es un hecho que, como Paul Farmer expresa, "la idea de que ciertas vidas importen menos que otras, es la raíz de todo lo que está mal en el mundo". ${ }^{3}$

Como afirma Miguel Carbonell: "El problema radica, y en eso debemos ser muy claros, en una mirada no jurídica, sino so-

3 Farmer, Paul, Pathologies of Power: Health, Human Rights, and the New War on the Poor, Berkeley, University of California Press, 2004. 
cial y, de hecho, religiosa del derecho. La cual es por principio totalmente ajena al ámbito jurídico, cuya cualidad de laicidad debe permanecer en el centro de su reflexión, de su acción y de su labor legislativa". ${ }^{4}$

El debate en torno al tema de la adopción por parejas del mismo sexo tiene que ver con la expresión y la legitimación ante la sociedad de que las uniones homosexuales son tan válidas como las uniones heterosexuales. La razón por la cual la Iglesia y los grupos conservadores se oponen a reconocer que a la unión de parejas homosexuales se les denomine matrimonio, tanto en su carga simbólica como expresiva, va más allá de los derechos patrimoniales y personales. La riqueza de dicha institución hoy en día se encuentra sobre todo en lo que representa culturalmente en nuestra sociedad; puesto que además de ser un acto jurídico, el matrimonio es un vehículo de expresión cultural, y de su manera de socializar una decisión, una forma de vida. Siguiendo con la reflexión sobre el tema, Carbonell afirma: "El dotar de esta vía expresiva a las parejas homosexuales es análogo al derecho que se le otorga a los creyentes a manifestarse públicamente en su culto. Es tener una preferencia íntima y poder vivirla ante la sociedad como algo legítimo". ${ }^{5}$

Debemos preguntarnos: ¿por qué es tan molesto o perturbador pensar en el derecho que tienen las parejas homosexuales a adoptar [para un sector de la sociedad]?, ¿por qué algunos grupos se cierran con tanta vehemencia a la idea de nuevos modelos de familia?, ¿qué tienen que perder?, ¿por qué tanto miedo? A lo que responde la académica y feminista Marta Lamas:

Se trata aquí de proteger un privilegio. La experiencia muestra que la sociedad y los padres no tratan igual a sus hijos hombres que a sus hijas mujeres. Cuando se es heterosexual, o blanco, u hom-

\footnotetext{
4 Carbonell, Miguel, ponencia presentada en el foro "Derechos, ciudadanía y diversidad sexual", Comisión de Derechos Humanos del Distrito Federal, 9 y 10 de febrero de 2010.
}

5 Idem. 
bre, es decir, cuando se está del lado del grupo hegemónico, la normalidad impone, y no hay razón para reflexionar a propósito de la norma que nos hace sujetos de derechos. La inquietud que puede surgir frente a la democracia sexual que posibilita otras subjetividades es reconocer que el orden de las cosas no es necesariamente natural ni normal. Cuando cuestionamos la norma, la hegemonía, se produce un malestar, pues nos obliga a pensar que la heterosexualidad no es, por sí sola, normal o natural. ${ }^{6}$

Suponer que la decencia y el bien moral dependen de la familia, como este modelo ideal que reduce el bienestar social a una conformación ideológica que, además, ha probado su fragilidad, es defender un modelo único de pensamiento, de cultura, de costumbres, de perspectiva; es ir en contra de todo lo que la democracia supone y defiende.

Es precisamente en este espacio simbólico donde la adopción por parte de las familias homoparentales y el matrimonio entre personas del mismo sexo trascienden el interés de la comunidad homosexual. Porque afirman más que simbólicamente el principio del fin de una sociedad que distingue entre ciudadanos de primera y de segunda; es decir, son expresiones de la demanda de igualdad y de respeto a sus derechos humanos.

\section{III}

Respecto a la identidad de género que pueden asumir los hijos de familias homoparentales, y que parece ser parte de la oposición a su derecho a adoptar o reproducirse, los estudios comparativos entre familias heterosexuales y homosexuales muestran que los hijos de lesbianas y homosexuales siguen comúnmente la identidad de género heterosexual. Los hijos de las generaciones de los últimos 20 años de familias homoparentales muestran que la "preferencia" de los padres no define en nada su propia identidad sexual; mues-

6 Lamas, Marta, “¿Por qué tanto miedo?”, Proceso, México, núm. 1737, enero de 2010. 
tran que incluso en las familias en las que las madres o los padres intentaron definir a través de su educación la percepción de género de sus hijos, cada uno lo hizo con relación y de cara a sí mismo, a veces aferrándose con mayor intensidad a los roles tradicionales.

En cuanto a la orientación sexual, en todos los estudios realizados, la mayoría de los entrevistados se describe a sí mismo como heterosexual. De igual manera, las preocupaciones sobre dificultades en áreas como la conducta, la personalidad, la autopercepción, los juicios morales, la adaptación escolar o el desarrollo de la inteligencia carecen de una base empírica. Ningún estudio ha encontrado una asociación de causa entre algún problema en estas áreas y el haber sido criado por personas homosexuales. Si el temor es que los hijos de padres homosexuales sean a su vez homosexuales, cabe preguntarse ¿cómo es que los hijos de madres y padres heterosexuales asumen una orientación o preferencia sexual distinta a la de éstos?

El mayor riesgo que corren los hijos de lesbianas y homosexuales es un ambiente hostil a la homosexualidad fuera de sus casas, en los espacios públicos y otras instituciones como la escuela, y lo que cuestionan específicamente es más: el engaño, la verdad silenciada, la mentira piadosa, que daña su percepción de la realidad.

\section{Y como afirma Marta Lamas:}

Cuando los hijos de lesbianas y homosexuales crecen en una comunidad que muestra señales homofóbicas, evitan revelar la orientación sexual de sus padres o madres pues temen ser objeto de discriminación, lo que sí supone una violación a sus derechos humanos, pues los confina al ostracismo y la invisibilidad y los despoja de los derechos en cuyo nombre se quiere negar la existencia de sus propias familias. Además, en el ámbito público - del que todos somos responsables-, las actitudes hirientes de los compañeros y amigos se dan igualmente cuando se trata de niños de otro color de piel, de una religión distinta, de otra nacionalidad - provenientes de parejas de padres divorciados o madres solteras-, o con una discapacidad. El asunto es enseñar a los niños 
y a los adultos a respetar todas las diferencias y a no permitir la discriminación de nadie. ${ }^{7}$

Finalmente, alejándonos de la supuesta existencia natural de un modelo único de familia y teniendo en cuenta que "las familias" son producto de la evolución histórica y cultural de las distintas sociedades, hay que subrayar que las transformaciones de la sociedad exigen del Estado el reconocimiento y atención a los fenómenos emergentes. Las políticas públicas, particularmente en materia de derechos humanos, deben partir de diagnósticos actualizados que recojan los hallazgos científicos más recientes sobre la diversidad y complejidad en la que se van construyendo los vínculos familiares, y reconocer las nuevas problemáticas que afectan a las familias, como lo afirma la Declaratoria de la Ciudad de México Familias en el siglo XXI: realidades diversas y políticas públicas, editada y publicada por el PUEG y el Gobierno del entonces Distrito Federal, en 2009.

Las parejas del mismo sexo: las lesbianas y homosexuales, que sueñan con tener una familia, con poder educar a un hijo o una hija, con poder maternar, ver crecer y acompañar a un ser humano en su desarrollo y realización desde, si es posible, los primeros años de su vida hasta los últimos segundos de la suya, no son esos seres perversos ni deplorables en busca de destruir la vida de los infantes adoptados, contrario a la satanización de su diferencia; por ejemplo: quienes desean tanto devenir padres, son personas que provienen de familias por lo general con una noción de la ética, con valores acordes a sus propias percepciones de una buena vida, curiosamente sean religiosos o laicos, pero con una convicción ética abrazada a valores humanos. Las personas de las diversidades tienen una característica que incluso las hace más conscientes que quienes los discriminan; en general, por su propia experiencia, son personas que creen en la ética de la responsabilidad del otro, que la asumen en su día a día, en sus gestos, en su trabajo, en una lucha cotidiana desde sus trinche-

\footnotetext{
7 Ibidem, p. 55.
} 
ras, por su propia experiencia de discriminación, con un compromiso mayor con la dignidad humana, con la construcción de un mundo mejor para los que están por venir. Las parejas de las diversidades sexo-genéricas, tanto en México como en el extranjero, que conozco, y que han buscado construir su propia familia, no lo han hecho para hacer de ella un burdel de niños explotados, como deja traslucir el pensamiento de quienes rechazan esta posibilidad; todo lo contrario, se han convertido en espacios de sociabilización sanos, equilibrados, amorosos, con todo lo necesario para construir la personalidad de niños igualmente sanos, equilibrados, que se sienten amados y apoyados. Es decir, se han manifestado como todo lo contrario.

Discriminar a las personas de las diversidades sexo-genéricas como potenciales buenos padres de familia, ya sea de un infante procreado por ellxs mismxs, ya sea a través de la adopción, no difiere de quien discrimina a una pareja de afrodescendientes, a una mujer indígena, a un indigente, a un gitano o a un judío. Como dice Farmer, vuelvo a repetir: "La raíz de los problemas del mundo es considerar que ciertas vidas importan menos que otras", y ese es también el reclamo de las parejas del mismo sexo con deseos de adoptar; pueden darle una vida llena de amor, de desarrollo, de realización y de riqueza humana a pequeños cuya realidad personal y abandono de sus progenitores ha arrancado.

Una vez más pregunto: ¿el interés superior de quién, defienden aquellos que están en contra de tales posibilidades? El sistema de adopción en nuestro país está construido ya de manera tal que siendo heterosexuales hay que pasar por largos periodos de pruebas psicológicas y socioeconómicas; si una pareja del mismo sexo las pasa, ¿por qué negárselo? La explicación es clara y triste, como dice la feminista y activista afroamericana Shirley Chisholm: "Al final, anti-negro, anti-mujer - y yo añadiría antiidentidad sexo-diversa - y toda forma de discriminación es equivalente a la misma cosa: un anti-humanismo". ${ }^{8}$

8 Chisholm, Shirley, Unbought and Unbossed: Expanded 40th Anniversary Edition, 1973. 
He realizado un sobrevuelo sobre las preguntas de los detractores del derecho constitucional y legítimo que atañe a las parejas del mismo sexo a adoptar, y la inevitable relación al respeto a su diferencia. Lo que más les preocupa a quienes ven en este derecho al desarrollo realizado de las personas libremente, toca puntos que para ellos son delicados y sagrados. He hablado de 20 años de experiencia y de estudios tanto en Francia como en Estados Unidos en los que no ha surgido una sola prueba de que la identidad sexual de los padres afecte en ningún sentido la construcción de la identidad ni la salud ni su desarrollo en comunidad, y que el sueño sería que todos nuestros hijos e hijas, sobrinos y sobrinas, ahijados y ahijadas, ¡los herederos de este planeta!, pudieran crecer y desarrollarse en un ámbito amable, equilibrado, receptivo, respetuoso, incluyente más que tolerante, valorativo de las diferencias todas, tanto culturales y sexuales. Como dice Marta Lamas: quitarle esa posibilidad a cualquiera de aquellos que ya llegaron y quienes están por venir, es arrebatarles los más elementales derechos humanos, y eso sí es anticonstitucional a todas luces. Lo único que se ha probado, en los mencionados estudios sobre el tema, insisto, es que los hijos de dichas parejas homosexuales suelen ser más respetuosos, más incluyentes, más comprensivos de su riqueza y su diversidad, y curiosos y deseosos de conocer y respetar la diversidad de los otros, tanto cultural como socialmente.

Respecto al miedo de que la homoparentalidad afecte el orden social, Martine Gross y Mathieu Peyceré, autores de uno de los estudios consultados, explican que la inserción de las familias homoparentales en las leyes es una invitación a desligar lo biológico de lo jurídico y de lo social. Nociones que desde hace tiempo comenzaron a desligarse en otras formas de familia, aceptados por la norma tradicional y que, como indico más arriba, Marta Lamas explica con manzanitas, no tiene nada de normal ni de natural. Esta evolución es una invitación a desarrollar un trabajo apasionante desde el derecho civil y familiar, como desde los de- 
rechos humanos, que muestra la viveza del derecho cuando éste se permite adecuarse a la realidad. Fundar las instituciones y las nociones de derecho a partir de la transparencia y la ética de la responsabilidad y el compromiso paterno creará espacios de una verdadera protección intensa para los niños. Como afirman los autores tanto en Francia como en Estados Unidos - así como en México y el resto del mundo-, los cientos de millares de familias recompuestas ganarán en garantías y, sobre todo, en coherencia y claridad.

Como ya lo mencionamos, la aspiración de la universalidad de los derechos humanos encuentra en la defensa de la particularidad de los homosexuales y lesbianas a adoptar un espacio de aplicación plena, ya que habla de un principio de "no discriminación" y defiende el derecho de cada individuo a la libertad, a la igualdad, a la intimidad, etcétera.

Como afirman los autores del estudio citado,

...el universalismo es un principio según el cual las leyes no deben ser formuladas para la satisfacción de minorías particulares, sino para el bien general. Pero precisamente las reivindicaciones de los padres homosexuales conciernen una reforma global del derecho de la familia y de la filiación y no el establecimiento de leyes para una minoría. Dichas reivindicaciones son eminentemente universalistas, ya que se apoyan en principios fundamentales: la igual protección de todos los infantes, cualquiera que sea su entorno familiar, y la igualdad de todos los ciudadanos. ${ }^{9}$

Eric Fassin expone cómo cada país se desarrolla, y sobre todo desarrolla su derecho con una base tradicional, a partir de una idea medular, y crea espacios o ideales "intocables" desde eso que consideran "sagrado" para la concepción misma de una nación. La construcción de la libertad como principio fundador

9 Gross, Martine y Peyceré, Mathieu, Fonder une famille homoparentale, questions éthiques, juridiques, psycologiques et quelque réponses pratiques, Ramsay, 2005, colección J'al Lu, Bien-être, p. 24. 
parte en Estados Unidos de un modelo de familia específico de sus fundadores, por eso la libertad es su esencia, mientras que en Francia es la igualdad el principio rector, lo que explica la manera en que este tema se ha desarrollado en ambos países. Yo retengo para México que si hay un espacio de "sacralidad" en la Constitución de un país democrático, ésta debería residir en el apego a las garantías que defiende, en el reflejo de los derechos humanos que ésta protege. "La sacralidad" de una Constitución como la nuestra debería radicar en el respeto a estos derechos humanos, en donde la mención "hombres y mujeres son iguales ante la ley" implique que esos derechos humanos los protegen a uno y a otro, como el artículo reza, sin importar "su diferencia".

$\mathrm{Al}$ principio hablaba de la isla de los derechos humanos en que ha devenido la Ciudad de México - aun habiendo pasado un proceso en un pasado reciente de impugnación por parte de la PGR y la CNDH, frente al cual se presentó un amicus curiae extraordinario en defensa de los derechos de las comunidades LGBTI, cuyos intereses se veían afectados con tales impugnaciones; la SCJN negó la necesidad de someter a dicha Constitución a alguna clase de audiencia pública, guardando íntegro el texto de dicha Constitución, que mantuvo en su contenido los avances que se habían logrado en los últimos años en materia de derechos de las diversidades - , de manera tal que se mantiene, a pesar de los atrasos culturales y sociales frente al respeto de las diversidades, siendo un espacio para la libertad y el desarrollo humano de las personas que conforman dichas diversidades, frente a una mayoría del territorio nacional.

Es por ello que no puedo más que manifestar mi deseo para que, algún día, esta isla se extienda a lo largo del territorio nacional, porque eso significaría en muchos aspectos que México se habrá convertido en ese país con el que soñamos; no de "tolerancia", sino de respeto, de aplicación de los derechos humanos, de consideración, reconocimiento y valoración de las diferencias todas, consciente de la violencia que engendra la discriminación y capaz de enfrentarla como una nación adulta, evolucionada 
y armónica. Ideal del cual, hoy por hoy, todos nos sentimos tan lejos desde distintas trincheras, sin entender cuán responsables somos de tal violencia y de dicho alejamiento del país con el que soñamos ser.

\section{$\mathrm{V}$}

Para concluir, y respecto a la conformación de nuevas formas de familia que vienen desarrollándose desde hace más de dos siglos, pero que la necesidad de querer meter a la humanidad entera en un molde único, y una vez defendida ésta, la necesidad y la estrategia que implica reapropiarse de la institución más vieja y arcaica, así como patriarcal, de la cultura occidental, y convertirla en una bandera de la defensa de las diversidades, quiero compartir cómo la defensa y la crítica cultural, de género y posmoderna se debaten en mí, y cómo ambas las considero igualmente importantes. Contradicciones que son el resultado del trabajo en estos años sobre las diversidades sexo-genéricas y la apuesta de los distintos grupos de dichas diversidades de la comunidad LGBTI, cuyo carácter posmoderno hace de su trabajo de reflexión uno en constante flujo, lo que hace difícil para espacios como el derecho, retener una postura única, cuya sola constante debe ser el derecho de autodeterminase de cada persona.

Quiero aclarar que los cuestionamientos que me genera la cercanía a nuevos grupos en mi panorama, como ciertos feminismos radicales o grupos trans, la pregunta ¿hasta dónde exigir el derecho al matrimonio igualitario, un "matrimonio para todxs"?, como lo llamaron en Francia en los últimos años, en donde se dio una discusión muy similar a la que se da hoy en México, y es que, partiendo del "derecho humano al matrimonio" que consagra la ONU, la siguiente pregunta es si luchar por ese derecho no nos lleva a querernos integrar y homogeneizar con el sistema patriarcal heteronormativo, buscando adquirir para nosotrxs los mismos moldes de comportamiento que la heteronormatividad 
impone. ¿Realmente pensamos en la igualdad como una adecuación de nuestro yo al molde tradicional? Personalmente creo que hablar de igualdad sustantiva se refiere a todo lo contrario, es decir, a la capacidad de un Estado a reconocer en todas y cada una de las diferencias y diversidades el valor de los elementos culturales, sociales e individuales que las conforman, reconocer que el modelo homogéneo heteronormativo no funciona para alcanzar la igualdad para cada una de estas diversidades, porque no protege o considera, tanto en las leyes como en la cotidianidad de las personas, todas esas especificidades que hacen su diferencia, y las excluye, en tanto mujeres, homosexuales, lesbianas o trans, las excluye en tanto indígenas, afrodescendientes, pobres, en tanto hablantes de otras lenguas y dialectos, en cuanto a su falta de acceso a la justicia cuando ésta está construida para un modelo patriarcal y hegemónico.

Mi aspiración de la democracia y el Estado de derecho para México es que todxs contemos con las herramientas y las condiciones para que todas las personas podamos desarrollarnos y realizarnos acorde a nuestras propias ideas y percepción de la felicidad y de una vida buena, como lo define el PNUD, y que la diversidad de familias y formas de organización social es tan variada y múltiple que debe ser reconocido su valor y su realidad. Además, reconocer que para una parte importante de la población, la búsqueda no está en integrarse en el modelo heteronormativo de familia clásica. Así que dejo abiertas las preguntas en ese sentido. Lo que sí concluyo respecto a las responsabilidades del Estado frente a las comunidades de la diversidad, es que éste está obligado a crear dichas condiciones, y que desde la posibilidad de ejercer derechos relacionados con la solidaridad entre las parejas o con la red de seguridad que hoy define un concepto de familia incluyente, estos avances permiten y generan posibilidades desde los afectos, que implican que nada ni nadie pueda arrebatar a una mujer o a un hombre el derecho a acompañar a su pareja en el hospital, o contar con las instituciones necesarias para no ser despojados del patrimonio construido juntxs y/o 
para lxs hijxs que han decidido proteger e integrar en su propia célula, llámese familia, red de seguridad, etcétera. La contradicción permanece; en la primera parte de mi texto creo conciliarla de alguna forma, pero queda abierta para mí misma, para quien quiera compartirla y profundizarla. No puedo dejar de pensar en la manera en que el Partido Republicano en Estados Unidos, una vez que comprendió que la comunidad LGBTI, particularmente la gay, implicaba un voto interesante, precisamente por su tendencia, en ciertos niveles y posturas, a convertirse en moldes listos a conformarse en copias de su propio sistema tradicional, repitiendo los mismos roles conservadores, esta pregunta me quedará siempre con un resquemor: ¿cuál es nuestra apuesta? Y lo único que sé es que no se trata de homogeneizar la elección de la diversidad de vidas posibles para ser aceptadxs, sino abrir los referentes para que la diversidad se expanda, se realice y se desarrolle.

\section{BIBLIOGRAFÍA}

BuTLER, Judith, Humain, inhumain. Le travail critique des normes. Entretiens, París, Éditions Amsterdam, 2005.

Carbonell, Miguel, Ponencia presentada en el foro "Derechos, ciudadanía y diversidad sexual”, México, Comisión de Derechos Humanos del Distrito Federal, 9 y 10 de febrero de 2010.

FARMer, Paul, Pathologies of Power: Health, Human Rights, and the New War on the Poor, Berkeley, University of California Press, 2004.

FAssin, Eric, Au-delà du PaCS. L'expertise familiale à l'épreuve de l'homosexualité, París, Presses Universitaires de France, 2005, colección Politique aujourd'hui.

FASSIN, Eric, "Matrimonio homosexual: entre la doble moral liberal y el conservadurismo", Suplemento Letra S, núm. 162, 7 de enero de 2010. 
Esta obra forma parte del acervo de la Biblioteca Jurídica Virtual del Instituto de Investigaciones Jurídicas de la UNAM

Gross, Martine y Peyceré, Mathieu, Fonder une famille homoparentale, questions éthiques, juridiques, psycologiques et quelque réponses pratiques, Ramsay, 2005, colección J'ai Lu, Bien- être.

LAMAS, Marta, “¿Por qué tanto miedo?”, Proceso, México, núm. 1737, enero de 2010.

\section{ANEXo. Gronología DEL MATRIMONIO IGUALITARIO EN MÉXICO}

\begin{tabular}{|l|l|l|l|}
\hline 2017 & Puebla & SGJN & $\begin{array}{l}\text { Legalización } \\
\text { del matrimonio } \\
\text { igualitario en Puebla }\end{array}$ \\
\hline $\begin{array}{l}17 \text { de } \\
\text { mayo } \\
\text { de } 2016\end{array}$ & $\begin{array}{l}\text { Enrique } \\
\text { Peña Nieto, } \\
\text { presidente }\end{array}$ & $\begin{array}{l}\text { Iniciativa a nivel } \\
\text { nacional de } \\
\text { "matrimonio sin } \\
\text { discriminación. }\end{array}$ & $\begin{array}{l}\text { Iniciativa de ley } \\
\text { para hacer de } \\
\text { obligatoriedad } \\
\text { nacional el } \\
\text { matrimonio } \\
\text { igualitario. }\end{array}$ \\
\hline $\begin{array}{l}\text { 12 de } \\
\text { junio } \\
\text { de 2015 }\end{array}$ & SCJN & $\begin{array}{l}\text { Obliga a todos } \\
\text { los jueces a seguir } \\
\text { el criterio de la } \\
\text { resolución en } \\
\text { la República } \\
\text { favorable a todos } \\
\text { los amparos que se } \\
\text { interpongan a favor } \\
\text { de este matrimonio } \\
\text { igualitario en los } \\
\text { estados en donde no } \\
\text { esté legalizado. }\end{array}$ \\
\hline
\end{tabular}


Esta obra forma parte del acervo de la Biblioteca Jurídica Virtual del Instituto de Investigaciones Jurídicas de la UNAM

\begin{tabular}{|c|c|c|c|}
\hline $\begin{array}{l}11 \text { de } \\
\text { enero } \\
\text { de } 2007\end{array}$ & Coahuila & $\begin{array}{l}\text { Marco jurídico } \\
\text { estatal. } \\
\text { Primera entidad } \\
\text { federativa donde } \\
\text { fue posible } \\
\text { el registro de } \\
\text { parejas del } \\
\text { mismo género. }\end{array}$ & $\begin{array}{l}\text { Para dar cabida a la } \\
\text { figura del PCS. }\end{array}$ \\
\hline 2007 & $\begin{array}{l}\text { PRD } \\
\text { Marcelo } \\
\text { Ebrard } \\
\text { ALDF }\end{array}$ & $\begin{array}{l}\text { Ley de Sociedad } \\
\text { de Convivencia. }\end{array}$ & Entra en vigencia. \\
\hline \multirow[t]{3}{*}{$\begin{array}{l}16 \text { de } \\
\text { noviembre } \\
\text { de } 2006\end{array}$} & $\begin{array}{l}\text { PRD } \\
\text { Marcelo } \\
\text { Ebrard } \\
\text { ALDF }\end{array}$ & $\begin{array}{l}\text { Ley de Sociedad } \\
\text { de Convivencia. }\end{array}$ & $\begin{array}{l}\text { Es aprobada por la } \\
\text { ALDF. }\end{array}$ \\
\hline & $\begin{array}{l}\text { Campeche } \\
\text { Ciudad de } \\
\text { México } \\
\text { Chihuahua } \\
\text { Coahuila } \\
\text { Colima } \\
\text { Jalisco } \\
\text { Michoacán } \\
\text { Morelos } \\
\text { Sonora } \\
\text { Nayarit } \\
\text { Quintana } \\
\text { Roo }\end{array}$ & $\begin{array}{l}\text { Legalizado el } \\
\text { matrimonio } \\
\text { igualitario. }\end{array}$ & $\begin{array}{l}\text { Todos los derechos: } \\
\text { seguridad social, } \\
\text { FOVISSSTE y } \\
\text { adopción de menores. }\end{array}$ \\
\hline & SCJN & $\begin{array}{l}\text { Primer partido } \\
\text { que considera } \\
\text { las diversidades } \\
\text { todas en sus } \\
\text { estatutos. }\end{array}$ & $\begin{array}{l}\text { Legalización entre } \\
\text { personas del mismo } \\
\text { sexo en Puebla. }\end{array}$ \\
\hline
\end{tabular}


Esta obra forma parte del acervo de la Biblioteca Jurídica Virtual del Instituto de Investigaciones Jurídicas de la UNAM

\begin{tabular}{|c|c|c|c|}
\hline 1989 & $\begin{array}{l}\text { PRD, primer } \\
\text { partido que } \\
\text { contempla } \\
\text { en sus } \\
\text { estatutos las } \\
\text { diversidades } \\
\text { todas }\end{array}$ & $\begin{array}{l}\text { Capítulo II, } \\
\text { De la democracia } \\
\text { y garantías al } \\
\text { interior del } \\
\text { Partido. }\end{array}$ & $\begin{array}{l}\text { g) El Partido de } \\
\text { la Revolución } \\
\text { Democrática } \\
\text { reconoce la } \\
\text { pluralidad de la } \\
\text { sociedad mexicana, } \\
\text { por tanto, garantizará } \\
\text { la presencia de los } \\
\text { sectores indígenas, } \\
\text { migrantes, de la } \\
\text { diversidad sexual u } \\
\text { otros en sus órganos } \\
\text { de dirección y } \\
\text { representación, } \\
\text { así como en las } \\
\text { candidaturas a cargos } \\
\text { de elección popular } \\
\text { en los términos del } \\
\text { presente Estatuto y } \\
\text { sus reglamentos. }\end{array}$ \\
\hline 2000 & $\begin{array}{l}\text { PRD, Enoe } \\
\text { Uranga, } \\
\text { Asamblea } \\
\text { del Distrito } \\
\text { Federal }\end{array}$ & $\begin{array}{l}\text { Propuesta para } \\
\text { reconocer las } \\
\text { uniones civiles } \\
\text { entre personas } \\
\text { del mismo sexo. }\end{array}$ & $\begin{array}{l}\text { Esta figura } \\
\text { jurídica reconoce } \\
\text { derechos similares } \\
\text { a los de las parejas } \\
\text { heterosexuales, pero } \\
\text { no reconoce, entre } \\
\text { otros, el derecho } \\
\text { a la adopción, } \\
\text { otorgándole una } \\
\text { solución temporal. }\end{array}$ \\
\hline
\end{tabular}


Esta obra forma parte del acervo de la Biblioteca Jurídica Virtual del Instituto de Investigaciones Jurídicas de la UNAM www.juridicas.unam. $\mathrm{mx}$ https://biblio.juridicas.unam.mx/bjv

Libro completo en: https://goo.gl/sHxaH7

\section{GUERPOS, AUTONOMÍA Y FEMINISMOS}




\title{
REFLEXIONES SOBRE EL DERECHO A DECIDIR: DE LA DEFENSA DEL ABORTO A LA LUCHA POR LA DESESTIGMATIZACIÓN DEL TRABAJO SEXUAL
}

\section{Iris GONZÁLEZ GORTEZ}

\begin{abstract}
SUMARIO: I. Derecho a decidir sobre el propio cuerpo. II. Vulnerabilidad, precariedad y desigualdad social. III. Estigma y criminalización. IV. Consideraciones finales. V. Bibliografia.
\end{abstract}

Hablar de temas que atraviesan el cuerpo y las subjetividades nunca es sencillo, sobre todo cuando se trata del cuerpo de las mujeres y de cuestiones directamente relacionadas con el ejercicio de su sexualidad y el quebrantamiento de mandatos sociales. A finales de junio de 2017, en una charla sobre trabajo sexual con las feministas, trabajadoras sexuales y activistas Georgina Orellano y María Riot, escuché algo que me hizo cuestionarme muchas cosas sobre el feminismo y lo que hasta ese momento creía correcto y ético, según mi muy particular forma de ver y concebir la prostitución. Entre los argumentos y contraargumentos que iban y venían a favor y en contra del trabajo sexual, María Riot comentó una imposibilidad muy personal de comprender por qué muchas feministas eran capaces de defender el aborto como una de las múltiples formas que tenemos las mujeres de decidir sobre nuestros cuerpos, pero condenaban el ejercicio del trabajo sexual; fue entonces que vi una línea muy clara que atraviesa dos temas - en apariencia- abismalmente diferentes y me pregunté si de verdad era posible hablar y problematizar uno de ellos a través de los argumentos del otro. 
De lo anterior derivan tres preguntas: ¿se puede analizar la prostitución desde algunos de los argumentos o puntos centrales en la defensa y debate del aborto?, ¿cuáles de estos puntos y argumentos atraviesan ambos temas?, ¿es posible que, a través de dicho análisis, las feministas podamos llegar a un consenso generalizado? Posiblemente, el eje central común es que la percepción social y jurídica de ambos temas está trastocada por los prejuicios, la criminalización y la doble moral de un sistema terriblemente machista, misógino y patriarcal que limita al máximo las posibilidades de las mujeres de vivir y existir con dignidad.

\section{DERECHO A DECIDIR SOBRE EL PROPIO GUERPO}

El goce y el ejercicio de los derechos sexuales y reproductivos sigue siendo uno de los grandes retos en México ${ }^{1}$ y el mundo, especialmente cuando se trata de las mujeres, quienes conforman poco más del $50 \%$ de la población, mitad históricamente rebajada a ciudadanas de segunda categoría y víctimas de innumerables vejaciones. Esto se debe, por un lado, a la persistente imposición de pautas morales y religiosas y, por otro, a la discriminación, la pobreza y las condiciones actuales de impunidad ${ }^{2}$ e insensibilidad, típicas de un Estado patriarcal, que impiden el acceso a estos derechos tan básicos sin que se pueda hacer mucho para combatirlo de forma rápida y efectiva.

Usualmente, hablar del derecho a decidir sobre el propio cuerpo nos remite a la lucha — de más de 40 años - por la legalización y/o despenalización del aborto, abanderada por feministas, acompañadas de personas aliadas. Estos años de lucha han traído como consecuencia que no sólo las diversas corrientes del feminismo coincidan en que el aborto debe ser reconocido como

1 Robles Maloof, Jesús Roberto, Derechos de la mujer, moral sexual y prostitución: un debate pendiente, disponible en: http://cdhdf.org.mx/wp-content/uploads/2014/05/ dfensor_03_2012.pdf [fecha de consulta: 13 de noviembre de 2017].

2 Idem. 
una de las múltiples manifestaciones de la libertad de las mujeres, sino que cada día más personas — no forzosamente feministasconcuerdan con esta idea en mayor o menor medida y con los diversos matices que sabemos que existen.

Pero ¿qué es decidir sobre el propio cuerpo? En este contexto, es la posibilidad de usar la libertad para tomar decisiones autónomas sin la interferencia - restrictiva - de terceros, incluyendo al Estado. Dado que "la existencia de los seres humanos es corporal, el derecho a tomar decisiones sobre el propio cuerpo es definitivo. Los cuerpos son la síntesis de un proceso biológico, una estructura psíquica, una producción cultural y un momento histórico". ${ }^{3}$

La lucha por la defensa y el reconocimiento del trabajo sexual - en términos globales — ${ }^{4}$ es relativamente reciente, por lo tanto, no se puede decir que haya un punto de vista único y general entre las feministas. Hay cinco posturas básicas que con frecuencia influyen en las legislaciones y políticas públicas de los países alrededor del mundo: 1) el prohibicionismo, que penaliza la prostitución e implementa medidas correctivas; 2) el reglamentarismo clásico, que controla el ejercicio de la prostitución a través de la zonificación, el licenciamiento y las evaluaciones médicas periódicas; 3) el abolicionismo, que ve el ejercicio de la prostitución como contrario a la dignidad de las mujeres y considera deseable su erradicación, sin embargo, se pronuncia en contra de cualquier tipo de regulación, legalización o penalización de dicha práctica; 4) la descriminalización o abolicionismo moderno, que promueve los derechos de quienes ejercen la pros-

3 Lamas, Marta, Algunas reflexiones relativas al derecho a decidir sobre el propio cuerpo, disponible en: https://programaddssrr.files.wordpress.com/2013/05/algunareflexiones-relativas-al-derecho-a-decidir-sobre-el-propio-cuerpo.pdf [fecha de consulta: 12 de noviembre de 2017].

4 Fue en la década de los años setenta que se empezaron a hacer movilizaciones con el fin de reivindicar los derechos de las trabajadoras sexuales, pero éstas se focalizaron principalmente en Estados Unidos, Canadá y Gran Bretaña. 
titución y la remoción de toda penalización a la práctica, pero sí busca la penalización de terceros involucrados, entre ellos el cliente, y 5) la legalización o neo-reglamentarismo o reglamentarismo liberal, que entiende la prostitución como una forma de prestación de servicios y la reivindica como una fuente de ingresos legítima y una manera de ejercer la autodeterminación. ${ }^{5}$

Actualmente, el sistema predominante es el abolicionismo moderno, que condena cualquier forma de reglamentación de la prostitución, por considerarlo - en todas sus formas - una forma de violencia contra la mujer. Según este sistema, las mujeres en "situación de prostitución" son consideradas víctimas, por lo que entre sus propuestas principales están los programas de concientización y reeducación.

En la actualidad, las normas jurídicas y sociales permiten el uso del cuerpo para llevar a cabo algún oficio o profesión, pero únicamente cuando esto se interpreta como la venta de la fuerza de trabajo como empleada, obrera o profesional, no así cuando se trata de la venta de sexo, pues resulta escandaloso, indecente e indigno, ya que la mujer en cuestión se convierte en "el receptor de los fluidos sexuales del varón, es decir, en objeto"; ${ }^{6}$ sin embargo, como bien señala Cristina Garaizabal:

La dignidad de las personas está por encima del trabajo que realizan, sea cual sea este trabajo. Una cosa es considerar que las condiciones en las que se ejerce la prostitución son, en muchos casos, indignas, y otra muy diferente que lo indigno es ejercer este trabajo. Una cosa es que ellas, llevadas por la interiorización del estigma, se sientan indignas... y otra es que se los confirmemos desde el feminismo. ${ }^{7}$

5 Torres, Claudia, Sobre modelos de regulación de la prostitución y el régimen legal vigente a nivel federal y en el Distrito Federal, México, Centro de Investigación y Docencia Económicas, 2014, pp. 2-6.

6 Villalba Augusto, Cristina y Álvarez Lucena, Nacho (coords.), Cuerpos políticos y agencia. Reflexiones feministas sobre cuerpo, trabajo y colonialidad, Granada, Universidad de Granada, 2011, p. 136.

7 Idem. 
Lo ideal es que ninguna persona tuviera que ejercer un oficio que la haga sentir incómoda, y pensar en alternativas viables podría ser una aportación valiosa de quienes se asumen abolicionistas o de quienes no estamos del todo de acuerdo con el mercado sexual; sin embargo, esto jamás deberá implicar una labor "educadora" hacia las trabajadoras sexuales en la que se les diga qué está bien y qué está mal, y mucho menos en la que se acallen y banalicen sus peticiones y sus luchas.

Es indiscutible que el ejercicio de la prostitución o trabajo sexual implica una cosificación del cuerpo de las mujeres por parte de quien paga por el servicio, y el fin de este texto no es defenderle, lo que resulta conflictivo y cuestionable es la idea de que ninguna mujer puede decidir ejercerlo con libertad y que todas son víctimas, como si nuestra realidad y nuestra forma de concebir ciertas prácticas fuera la única. Esta concepción no sólo es paternalista, sino que lleva implícita una infantilización nada nueva. La imposición de ideas es fuerte y las soluciones para resolver dicho "problema" son nulas, las trabajadoras sexuales - como muchas de ellas se asumen - siguen en el limbo jurídico y orilladas a ejercer la prostitución en condiciones deplorables.

Desde los feminismos siempre se ha defendido la capacidad de decisión de las mujeres, por lo tanto, es fundamental que los sectores más vulnerados se tengan en cuenta y se potencie esta capacidad de decisión. ${ }^{8}$ Lo más importante es tener claro que esta labor de protesta y exigencia tendrá que llevarse a cabo hombro con hombro, pero jamás hablando por ellas, ni desde la academia ni desde el activismo y mucho menos desde las instituciones gubernamentales.

\section{VULNERABILIDAD, PREGARIEDAD \\ Y DESIGUALDAD SOCIAL}

Cuando se trata de aborto, es bien sabido que son las mujeres que viven en condiciones precarias las que resultan más afectadas,

$8 \quad$ Ibidem, p. 151. 
porque incluso el acceso al aborto legal se ve trastocado por las desigualdades. En este sentido, es la integridad física y emocional de mujeres pobres la que se ve afectada con mayor regularidad, ya sea por imposibilidades económicas de acceder a procedimientos seguros o por el simple desconocimiento de sus derechos.

Con las trabajadoras sexuales sucede algo similar, pues el grado de vulnerabilidad se multiplica por ser mujeres, por ejercer la prostitución y por las condiciones de pobreza en las que viven muchas de ellas. Esto, como es de esperarse, se agudiza cuando tienen alguna discapacidad, son indígenas, adultas mayores o pertenecen a cualquier otro grupo marginado.

El marco jurídico mexicano en materia de prostitución es bastante heterogéneo, es decir, es posible encontrar varios sistemas conviviendo a la vez. El ejercicio de la prostitución no es ilegal, sin embargo, algunas entidades federativas han decidido apegarse al sistema reglamentarista clásico e implementar reglamentos que regulen su ejercicio a través de la delimitación de zonas en las que está permitido llevar a cabo el comercio sexual, el otorgamiento de permisos o licencias, la realización de chequeos médicos periódicos y otra serie de disposiciones que no sólo son retrógradas y se prestan — siendo México un país con altos niveles de corrupción - a diversas formas de extorsión hacia las trabajadoras sexuales, sino que también fomentan la estigmatización, pues se les concibe como portadoras de infecciones de transmisión sexual y, por tanto, un peligro para la población. Aunado a esto tenemos la implementación de la Ley General para Prevenir, Sancionar y Erradicar los Delitos de Trata de Personas para la Protección y Asistencia a las Víctimas de estos Delitos, que se apega al abolicionismo moderno y que ha traído una ola de criminalización y prohibicionismo consecuencia de la confusión entre trata y trabajo sexual. La ley de trata ha servido como pretexto para definir la prostitución no forzada como violencia contra las mujeres, confundiendo el hecho de intercambiar servicios sexuales por dinero, con otros fenómenos concomitantes 
como los abusos, la violencia, la marginalidad y el estigma, ${ }^{9}$ que sí están ligados al machismo, la misoginia y otras cuestiones de género, pero que también son perpetuados a través de la negación del reconocimiento y la criminalización de dicha actividad, pues trae como consecuencia la clandestinización de esta práctica y no coadyuva en lo absoluto a erradicar la prostitución forzada y la trata con fines de explotación sexual.

El hecho de que esta actividad no sea reconocida como trabajo (que no se les permita organizarse sin depender del Estado, crear sindicatos y tener acceso a las prestaciones de ley y a los derechos más básicos) no hace que la prostitución deje de existir; por el contrario, deja a las trabajadoras sexuales en total desamparo y con pocas posibilidades de tener una vida digna.

Muchas trabajadoras sexuales se ven obligadas a vivir y ejercer la prostitución en barrios conflictivos y peligrosos, quedando a merced de la delincuencia y la corrupción policial. Cristina Garaizabal señala que:

Las condiciones de alegalidad en las que se mueve la prostitución, la falta de reconocimiento de esta actividad y el que sea un trabajo sumergido, realizado de una forma semiclandestina, imprimen una dureza particular a las condiciones en las que se desarrolla. Trabajar en la prostitución cuesta esfuerzo y supone, demasiadas veces, aguantar penalidades varias, derivadas de la estigmatización y la consideración social que tienen las mujeres que se dedican a ello. ${ }^{10}$

No obstante la gravedad del problema, se siguen poniendo todos los esfuerzos en arremeter contra la prostitución, sin el más mínimo interés en cambiar las condiciones que favorecen que algunas prostitutas sufran diferentes formas de violencia. ${ }^{11}$

$9 \quad$ Ibidem, p. 139.

$10 \quad$ Ibidem, p. 137.

11 Idem. 


\section{ESTIGMA Y GRIMINALIZAGIÓN}

Sin duda, uno de los temas que tocan con mayor claridad los temas de aborto y trabajo sexual son el estigma y la criminalización a los que son sometidas las mujeres en cualquiera de los dos casos. Cuando de aborto se trata, la respuesta es clara y tajante, tanto por parte de la sociedad como del orden jurídico: abortar está mal, la mujer que lo hace falla a sus roles de género y a una supuesta naturaleza inherente a ella. Más allá de su subjetividad y deseos está la vida del producto, y nada más importa; por lo tanto, quien atente contra este mandato jurídico y social será señalada, perseguida y juzgada como sujeta indeseable, transgresora y delincuente. Pero, ¿de qué forma funcionan el estigma y la criminalización cuando se trata de trabajo sexual?

En sociedades patriarcales como la nuestra, a pesar de los importantes avances que se han dado en el terreno de la sexualidad, las mujeres seguimos siendo juzgadas por nuestros comportamientos sexuales - y reproductivos - en mayor medida que los hombres, ${ }^{12}$ de ahí la constante clasificación entre mujeres buenas y malas que está tan interiorizada y enraizada en el subconsciente de hombres y mujeres. Esto se puede ver manifestado en su máxima expresión en la valoración que se hace de las trabajadoras sexuales, sector sumamente estigmatizado a través de la distinción que se hace sobre ellas como una categoría especial de mujeres, distintas del resto: por un lado, como viciosas, enfermas o perversas, y por otro como víctimas, analfabetas o ignorantes; como si sólo existieran esos dos matices y no hubiera otras realidades, negando toda la capacidad de solidaridad, superación, identidad y dignificación que tienen y que reivindican un número considerable de mujeres que se dedican a la prostitución.

La estigmatización sobre las trabajadoras sexuales funciona como instrumento de control para que las mujeres nos atengamos a los límites que aún hoy encorsetan la sexualidad femenina: ${ }^{13}$

\footnotetext{
12 Ibidem, p. 131.

13 Ibidem, p. 132.
} 
La ideología dominante hace especial hincapié en el peligro que supone para las mujeres el placer sexual. Hay que ser "buenas" mujeres para sentirnos protegidas. Si eres "mala" es lógico que te agredan, que te pase cualquier cosa. Las buenas mujeres son sujetos de derecho y protección, pero las malas, especialmente si se empeñan en seguir siéndolo, quedan desprotegidas y pierden todo tipo de derechos. ${ }^{14}$

Tal pareciera que los derechos son negociables, que dependiera de nuestra obediencia el tener acceso al disfrute de ellos o no, porque, aunque formalmente se sabe que no es así, en la realidad esto es lo que sucede. Se asume que todo lo malo que nos ocurre es porque nos lo buscamos: si nos violan es por cómo íbamos vestidas; si nos matan es porque seguro lo provocamos, y si nos acosan sexualmente es por la hora o el lugar en el que estábamos.

Y ¿qué pasa con la criminalización? Hablar de criminalización es importante porque, a diferencia de la "penalización", ésta nos remite a procesos que no son estrictamente jurídicos, sino también sociales. Uno de los grandes problemas con los sistemas abolicionistas es que, posiblemente sin ser esa la intención, terminan fomentando la criminalización; esto deriva no sólo en la afectación directa de la mujer en cuestión, sino en la criminalización a clientes, familiares o parejas sentimentales (en el caso de estos dos últimos, por ser considerados sus proxenetas), el cierre de los establecimientos en los que ejercen dicha actividad, el hostigamiento policial y hasta la pérdida de la patria potestad de sus hijos e hijas.

Tanto las medidas abolicionistas como las reglamentaristas coartan el acceso a derechos humanos de las mujeres que ofrecen servicios sexuales y afectan su estatus de ciudadanas a través de la simplificación de los discursos, las medidas discriminatorias a las que son obligadas a someterse y el carácter paternalista de sus postulados. La claridad y la coherencia son fundamentales, y ya

14 Idem. 
ha quedado clara la ineficacia de tratar de imitar modelos que han funcionado de manera parcial en otros países, a costa del bienestar de un número importante de mujeres, pero que nada tienen que ver con la realidad que vivimos en México.

\section{Consideraciones Finales}

El cruce de ambos temas es indiscutible y vale la pena profundizar en ello, sobre todo en lo referente al reconocimiento de la autonomía y la percepción de las mujeres como plenas sujetas de derecho. Es posible que posicionarnos en algunos de los ejes fundamentales del debate sobre el aborto nos permita tener una percepción más clara de por qué sí es necesario luchar por el reconocimiento del trabajo sexual y, por ende, el respeto a las mujeres que lo ejercen.

No se trata de defender posiciones definitivas o promover el comercio sexual, y mucho menos de proteger y justificar al cliente o consumidor, sino de pensar que es una realidad y que, por mucho que nos cueste comprenderlo, puede ser que sí haya mujeres que ejercen la prostitución por decisión propia, y ¿quiénes somos las feministas para decir que eso es imposible?, ¿qué nos hace superiores a esas mujeres para poder afirmar que no son capaces de decidirlo? Esto no quiere decir que no haya una estructura social que lleve a las mujeres a tomar este tipo de decisiones, y la idea no es que los feminismos defiendan el ejercicio de la prostitución, más bien se trata de hacer una ponderación y ver qué es más benéfico y eficaz. Se trata de defender los derechos de quienes se autodenominan trabajadoras sexuales, de tal manera que puedan vivir sin el riesgo constante de verse afectadas en su integridad física o psíquica.

Luchar por el reconocimiento de los derechos de las trabajadoras sexuales no es promover dicha actividad ni pensar que es el mejor de los oficios, así como estar a favor del aborto no es desear que todas las mujeres interrumpan algún embarazo en el transcurso de sus vidas. Se trata de justicia social, de brindar y 
luchar por todos los derechos de todas las personas, más allá de que podamos o no comprender sus realidades.

\section{BIBLIOGRAFÍA}

JULIANO, Dolores, La prostitución: el espejo oscuro, España, Icaria Editorial, 2002.

OsBORne, Raquel, Trabajador@s del sexo: derechos, migración y tráfico en el siglo XXI, España, Bellaterra, 2004.

TORRES, Claudia, Sobre modelos de regulación de la prostitución y el régimen legal vigente a nivel federal y en el Distrito Federal, México, Centro de Investigación y Docencia Económicas, 2014.

Villalba Augusto, Cristina y Álvarez Lucena, Nacho (coords.), Cuerpos políticos y agencia. Reflexiones feministas sobre cuerpo, trabajo y colonialidad, España, Universidad de Granada, 2011. 


\title{
TERRITORIOS POSIBLES PARA NOSOTRAS. CLAVES INTERPRETATIVAS PARA LEER EL OCIO FESTIVO
}

\author{
Ángela RIVERA MARTÍNEZ \\ Victoria LÓPEZ RoseTE
}

Salimos a quemar la ciudad mientras dormías.

Martha MEgA

SUMARIO: I. Introducción. II. Espacio, lugar y territorio. III. Prácticas corporales. IV. Cierre preliminar: ¿atisbos de una política nocturna?

\section{INTRODUCGIÓN}

Hemos encontrado en el baile y en los diversos espacios en que éste acontece, una serie de entramados que dan cuenta de autonomías relativas, subversiones, reproducciones y, sobre todo, redes y construcción de territorios con distintos grados de permanencia - e incluso efímeros - los cuales crean y recrean afectividades, estéticas, estilos y territorios posibles para nosotras. Por ello, nos proponemos reflexionar sobre la creación y la reapropiación de territorios sostenidos a partir de un deseo de estar juntas a través del ocio festivo y el baile, entendiendo éste como práctica corporal; no obstante, esta reflexión está inscrita en una problemática mayor: salir y habitar un afuera no pensado para las mujeres, y menos para las 
lesbianas, al interior de sociedades que históricamente han estado atravesadas por un repliegue falogocéntrico, el cual no ha cesado luego de siglos de transformaciones sociales.

El presente texto está dividido en tres apartados. Primero introducimos la definición de los conceptos espacio, lugar y territorio, para, a continuación, establecer qué entendemos por baile y ocio festivo, y cómo éstos se pueden traducir en modos de ocupar el espacio y significar territorios. Por último, ofrecemos algunos apuntes a partir de la articulación de ambos desarrollos con el objetivo de dejar abierta la discusión. Tomaremos como soporte reflexivo algunas experiencias vividas en contextos de ocio festivo en la Ciudad de México. Partimos de la noción de $e x-$ periencia como principal herramienta de validación. De acuerdo con Scott, ${ }^{1}$ la experiencia es aquel elemento que constituye a las y los sujetos, y no "algo" que éstos poseen a priori de su constitución. Este trabajo es fruto de la necesidad de pensar a través de epistemologías que parten desde la experiencia subjetiva y el cuerpo, en las que están en juego otras formas de producir sentido y conocimiento. Los derroteros de esta reflexión no pretenden dar forma a una propuesta hermética, sino, por el contrario, ofrecer claves de interpretación para pensar el presente y abrir el debate.

\section{ESPACIO, LUGAR Y TERRITORIO}

Michel de Certeau establece una diferencia entre las nociones de espacio y lugar. De acuerdo con esta distinción, el espacio es un entrecruzamiento de movilidades; no es el origen del movimiento, sino el efecto de las movilidades que en él se despliegan: "[E]s el efecto producido por las operaciones que lo orientan, lo circunstancian, lo temporalizan y lo llevan a funcionar como una unidad polivalente de programas conflictuales o de proximidades

1 Scott, Joan, "Experiencia", en Butler, Judith y Scott, Joan (comps.), Feminist Theorize the Political, Nueva York, Routledge, 1992. 
contractuales". ${ }^{2}$ Por su parte, al hablar de lugar se alude a un ordenamiento en el espacio:

El lugar es el orden (cualquiera que sea) según el cual los elementos se distribuyen en relaciones de coexistencia. Ahí pues se excluye la posibilidad para que dos cosas se encuentren en el mismo sitio. Ahí impera la ley de lo "propio": los elementos considerados están unos al lado de otros, cada uno situado en un sitio "propio" y distinto que cada uno define. Un lugar es pues una configuración instantánea de posiciones. Implica una indicación de estabilidad. ${ }^{3}$

En la noción certeauriana de lugar se configuran estabilidades que pueden excluir el emerger de un encuentro, siempre que pensemos a éste como la apertura a lo posible. Las relaciones de coexistencia supondrían, entonces, una configuración de posiciones basadas en el desencuentro y, por ende, en la imposibilidad. La ley de lo "propio", como Certeau la llama, invoca de forma no explícita una cancelación de la heterogeneidad, ya que sólo a partir de ella es que se producen los encuentros.

Si, por definición, no existe lugar alguno para la apertura de posibles, ¿en dónde ocurre esta apertura? La respuesta es clara: no hay un lugar estable, definido ni permanente. La posibilidad pertenece, así, al reino de los acontecimientos. Ya lo dijo Mauricio Lazzarato: "un acontecimiento no es la solución de un problema, sino la apertura de posibles". ${ }^{4}$ Así, pues, acontecimiento y encuentro se reúnen en una zona de vecindad en la medida en que ambos suponen una apertura de lo posible. Continúa Lazzarato:5 "Lo posible es de este modo producción

2 Gerteau, Michel de, La invención de lo cotidiano, México, Universidad Iberoamericana-ITESO, 2000, p. 129.

3 Idem.

4 Lazzarato, Mauricio, Políticas del acontecimiento, Buenos Aires, Tinta Limón, 2006, p. 45.

5 Ibidem, p. 49. 
de lo nuevo. Abrirse a lo posible es recibir, como cuando uno se enamora, la emergencia de una discontinuidad en nuestra experiencia, y construir, a partir de la mutación de la sensibilidad que el encuentro con el otro ha creado, una nueva relación, un nuevo agenciamiento".

A partir de esto, sostenemos que un acontecimiento será el efecto del encuentro entre singularidades heterogéneas. Diríamos, siguiendo a Deleuze, que el acontecimiento es el efecto incorporal de la mezcla entre cuerpos que se perciben y se experimentan a través de sus potencialidades y no a través de la imagen dogmática del pensamiento, cuyo yugo impide la creación de formas otras de sensibilidad a las que advienen formas otras de pensamiento. ${ }^{6}$

Aquí es donde entra la noción de territorio. Hablar de territorios supone una ocupación del espacio que no se agota en la configuración de estabilidades; un territorio puede ser relativo no necesariamente a un lugar, sino "a un espacio vivido, así como a un sistema percibido en cuyo seno un sujeto se siente en su casa". ${ }^{7}$ De acuerdo con lo señalado por Urteaga y Feixa, ${ }^{8}$ los territorios se articulan a través de intercambios afectivos y culturales que se construyen cotidianamente, y construyen, a su vez, modos de habitar el espacio, en la medida en que ellos mismos son, nuevamente siguiendo a Guattari y Rolnik, sinónimos de apropiación y subjetivación.

Los territorios son, entonces, zonas no estables de intercambios afectivos y culturales (encuentro entre singularidades heterogéneas, mezcla de cuerpos y potencialidades), en donde están puestos en juego modos de habitar, apropiaciones y procesos de

\footnotetext{
6 Deleuze, Gilles, Lógica del sentido, Barcelona, Paidós, 2005.

7 Guattari, Félix y Rolnik, Suely, Micropolítica. Cartografias del deseo, Madrid, Traficantes de Sueños, 2006, p. 372.

8 Urteaga, Maritza y Feixa, Carles, "De jóvenes, músicas y las dificultades de integrarse", en García Canclini, Néstor (coord.), La antropología urbana en México, México, Conaculta-Universidad Autónoma Metropolitana-Fondo de Cultura Económica, 2005.
} 
subjetivación, y, con esto, como antes señalamos, la apertura para el acontecimiento.

Los espacios pueden llegar a convertirse en territorios en función de las formas en que son habitados. Entre toda la multiplicidad de modos de habitar, a nosotras nos interesa específicamente el baile (y no la danza como forma de expresión artística) entre mujeres lesbianas. Partimos de la noción de baile que lo entiende como una serie de técnicas y prácticas corporales ${ }^{9}$ cuyo sentido depende de la posición discursiva y de enunciación de los agentes que participan en él. Nuestros supuestos son que a través del baile el espacio se multiplica en territorios tan singulares como heterogéneos y, además, que el cuerpo mismo se convierte en espacio de territorialización, lo cual implica una serie de procesos de subjetivación, significación y apropiación en distintas dimensiones.

\section{PRÁCTICAS CORPORALES}

Reparamos en los flujos que posibilitan el movimiento, así como en los desplazamientos de una categoría de análisis a otra; en este caso, del cuerpo hasta las prácticas corporales. Los flujos están dados por la noche y la ciudad; se expresan en los modos de habitar y en los territorios que cotidianamente recreamos, dando forma a nuestras propias configuraciones afectivas a partir de experiencias vividas e incorporadas.

Entendemos por prácticas corporales, utilizando como referencia el trabajo de Elsa Muñiz, ${ }^{10}$ una serie de usos intencionales y disciplinas de orden corporal, como señala la teórica, pero tam-

9 Le Breton, David, Sociología del cuerpo, Buenos Aires, Nueva Visión, 2011; Muñiz, Elsa, "Las prácticas corporales. De la instrumentalidad a la complejidad”, en Muñiz, Elsa (comp.), El cuerpo: estado de la cuestión, México, La Cifra Editorial, 2016.

10 Muñiz, Elsa, "Las prácticas corporales. De la instrumentalidad a la complejidad", op. cit. 
bién de aprendizajes que traen consigo la creación de imágenes y representaciones, tanto individual como colectivamente.

Esta noción recoge la posibilidad de entender a las corporalidades desde procesos de subjetivación producidos por un despliegue ${ }^{11}$ de prácticas y discursos. ${ }^{12} \mathrm{~A}$ su vez, introducir esta categoría de análisis abre la posibilidad de desestabilizar la dicotomía cuerpo-mente y de poner en el centro de la discusión un posible cambio de paradigma del poder, ya no únicamente constreñido a la administración de los cuerpos, es decir, a la biopolítica del poder disciplinario acontecida en un régimen liberal.

Por ejemplo, la psicopolítica, ${ }^{13}$ como otra forma de poder dentro del régimen neoliberal, nos invita a pensar en la vigencia de las matrices de pensamiento que se utilizan para producir conocimiento. Sin embargo, la propuesta de Han, sin ser revisada y situada, difícilmente puede tener un alcance como una clave interpretativa. Si dislocamos el entendimiento que escinde el cuerpo de la mente (como someramente lo señala Han) al plantearnos relaciones de poder situadas y cambiantes, ya no inscritas en las sociedades disciplinarias sino más bien en sociedades abigarradas, ${ }^{14}$ parte de un régimen neoliberal de orden glocal, entonces podremos acercarnos hacia una comprensión de las problemáticas del cuerpo desde un desplazamiento epistemológico clave en que no damos por superada una biopolítica, ni tampoco lo pensamos como una sumatoria de factores, sino que conside-

11 Teresa de Lauretis reinterpreta, a través de un ejercicio de traducción, la noción foucaultiana de dispositif como despliegue. En inglés deployment se traduce como desplegar, lo que, de acuerdo con la teórica, expresa la idea de "estrategia política".

12 De Lauretis, Teresa, "Sujetos excéntricos: la teoría feminista y la conciencia histórica", en Cangiamo, María y DuBois, Lindsay (comps.), De mujer a género, teoría, interpretación y práctica feministas en las ciencias sociales, Argentina, Centro Editor de América Latina, 2013.

13 Han, Byung-Chul, Psicopolítica, Barcelona, Herder, 2014.

14 Rivera Cusicanqui, Silvia, Ch'ixinakax utxiwa: una reflexión sobre prácticas y discursos descolonizadores, Buenos Aires, Tinta Limón, 2010. 
ramos la psicopolítica como una lectura necesaria para la complejidad del cuerpo y las prácticas corporales. La psicopolítica se inscribe en un capitalismo de la emoción y de las vivencias inmediatas de éxito que simulan continuidad. La experiencia, como señala Han, siguiendo a una larga tradición filosófica que pasa por Nietzsche, Blanchot, Bataille y Foucault, se posiciona frente a la vivencia, pues implica arrancar al sujeto de su sometimiento; por tanto, nos abre a la posibilidad del acontecimiento, de lo repentino, lo discontinuo y lo imprevisible. "El acontecimiento pone en juego un afuera que hace surgir al sujeto y lo arranca de su sometimiento. Los acontecimientos representan rupturas y discontinuidades que abren nuevos espacios". ${ }^{15}$

\section{Los espacios del ocio festivo}

El desplazamiento forzado de las mujeres a la esfera de lo doméstico es efecto de una desigual distribución del espacio físico y simbólico de larga data. Como bien sabemos, la polis griega era un espacio de hombres en el que las mujeres no gozaban de igualdad de condiciones, y aunque desde aquel entonces hasta ahora hayan transcurrido tantos siglos, el espacio destinado a las mujeres continúa siendo el menos privilegiado. Murillo ${ }^{16}$ introduce la categoría de lo doméstico, distinguiéndola de las categorías tradicionales de lo público y lo privado, ya que no considera que la vida doméstica pueda ser equivalente a la vida privada. La vida privada, de acuerdo con Murillo, permite abrir un momento de descanso y de ocio fuera de los ámbitos públicos de producción; la vida privada dota, entonces, de la posibilidad de construir un tiempo propio, lo cual se diferencia por oposición de la vida doméstica en la cual ni el tiempo ni el espacio son adecuados para

15 Han, Byung-Chul, op. cit., p. 115.

16 Murillo, Soledad, El mito de la vida privada. De la entrega al tiempo libre, Madrid, Siglo XXI, 1996. 
cultivar el cuidado de sí, sino más bien para volcarse hacia el cuidado de los otros. De este modo es que Murillo sostiene que, además de la vida pública, la privada es un privilegio destinado a los varones para que cultiven su individualidad, mientras que la vida doméstica ha sido históricamente el lugar conferido a las mujeres, una vida no de privacidad, sino de privación de sí mismas, definida en función de la reproducción, la crianza y una actitud encaminada al cuidado de los otros.

De acuerdo con este orden de ideas, al quedar constreñidas al espacio doméstico, en la lectura que propone la autora el ocio festivo también estaría estructuralmente vedado a las mujeres. Fuentes da un ejemplo de esto trasladándonos a México en los años sesenta cuando las actividades realizadas por hombres homosexuales y por mujeres lesbianas estaban marcadas por roles binaristas: "En México los hombres podían tener ciertos momentos de esparcimiento, ya fuera individualmente o de convivencia en grupo, por ejemplo, los baños de vapor, los billares y las cantinas". ${ }^{17}$ Mientras que las mujeres tuvieron que luchar por construir sus propios caminos, lugares y territorios que hicieran posible su encuentro. "[L]as mujeres que se atrevieron a exigir la entrada a sitios exclusivos para hombres [por ejemplo, cantinas donde explícitamente se prohibía la entrada a mujeres, uniformados y perros] se arriesgaron, sufrieron maltratos y golpizas, pero también encontraron estrategias para rehusarse a interpretar el papel de feminidad y de sexualidad que les habían asignado". ${ }^{18}$ Luchar por tener acceso a ciertos lugares en el ejemplo que tomamos de Fuentes (en el cual se centra específicamente en la vida de mujeres lesbianas) muestra una búsqueda absolutamente contraria al cultivo de la individualidad; es una lucha que apela al encuentro y a la construcción de espacios intersticiales. Con

17 Fuentes Ponce, Adriana, Decidir sobre el propio cuerpo. Una historia reciente del movimiento lésbico en México, México, La Cifra Editorial-Universidad Autónoma Metropolitana-Unidad Xochimilco, p. 115.

18 Ibidem, p. 122. 
Esta obra forma parte del acervo de la Biblioteca Jurídica Virtual del Instituto de Investigaciones Jurídicas de la UNAM

la noción de espacios intersticiales nos referirnos a producciones que tienen origen en las formas de socialidad dadas "por el deseo de estar junt [a]s sin más", 19 y construidos mediante gustos y estéticas afines. Éstos se originan principalmente en los espacios de ocio y recreación, y producen códigos nuevos, modos de organización contingentes y vínculos afectivos. ${ }^{20}$

"Si todos los espacios están colonizados queda el amparo del tiempo, el tiempo como refugio", señala Margulis. ${ }^{21}$ La cultura de la noche, como una tentativa de la desestabilización del tiempo definido por las actividades productivas, acoge nuevos espacios, zonas temporalmente autónomas ${ }^{22}$ liberadas del tiempo y del lugar de la institucionalidad, que se gestionan de maneras alternativas a la productividad dada por el día. La fiesta, el ocio festivo, el baile y sus múltiples versiones son en sí mismos la apertura de nuevos espacios. En este sentido, una fiesta puede entenderse como zona temporalmente autónoma, o al menos potencialmente, porque se asemeja a la revuelta; es decir, a diferencia de lo que se ha entendido como "revolución", la revuelta no quiere vencer al tiempo a través de la permanencia; es ella misma temporal. Las fiestas, así

19 Maffesoli, Michel, El tiempo de las tribus. El ocaso del individualismo en las sociedades posmodernas, Buenos Aires, Siglo XXI, 2004.

20 Urteaga, Maritza, La construcción juvenil de la realidad. Fóvenes mexicanos contemporáneos, México, Universidad Autónoma Metropolitana, 2011; Reguillo, Rossana, Emergencia de culturas juveniles. Estrategias del desencanto, Bogotá, Norma, 2007; Nateras, Alfredo, "Trayectos y desplazamientos de la condición juvenil contemporánea", El Cotidiano, 20 (126), 2004; Fuica, Inti y Vergara, Constansa, "Entramados de lo juvenil. Aproximaciones hacia las sociabilidades juveniles chilenas contemporáneas", Revista Latinoamericana de Ciencias Sociales, Niñez y fuventud, vol. 14, núm. 2, p. 967.

21 Margulis, Mario, La cultura de la noche. La vida nocturna de los jóvenes en Buenos Aires, Buenos Aires, Biblos Sociedad, 1994.

22 Una zona temporalmente autónoma es una forma de sublevación que libera un área - dice Hakim Bey, "de tierra, de tiempo, de imaginación"- y posteriormente se autodisuelve para reconstruirse en cualquier otro momento y localización, "antes que el Estado pueda aplastarla". Diríamos nosotras, sencillamente, antes de que pueda ser aplastada, ya que no sólo ese aparato detenta el poder de aplastamiento o de apropiación. 
como las revueltas, escapan a lo ordinario, no ocurren todos los días, "pero tales momentos de intensidad dan forma y sentido a la totalidad de una vida". ${ }^{23}$

Nos encontramos posibilidades de agenciamiento a través de prácticas que encuentran un sitio en esta noche - figurada-, en la nocturnidad efímera dada por una temporalidad específica, situada, en que la proximidad entre nosotras crea significados que "no aspiran a obtener legitimidad más allá del momento de la interacción, y permite... la construcción de espacios propios cuyas reglas de interacción surgen a partir de (las) propias búsquedas". ${ }^{24}$

Cuestionar el orden establecido por medio de la apropiación, de las interacciones entre semejantes, ${ }^{25}$ implica vivencias compartidas, el encuentro en un "tiempo y espacio separado de día, de ruptura con la experiencia de la vida «normalizada», de la cotidianidad productiva y de las relaciones estipuladas. La noche ha sido también espacio de minorías, de grupos exentos de la obligación productiva, de individuos ociosos, bohemios y marginales. Tiempo de no obligación y de indefiniciones". ${ }^{26}$ Un tiempo que, sin embargo, no puede pensarse exento de normatividades.

A partir del reconocimiento y la inquietud que nos provocan ciertos espacios de ocio festivo y baile, hemos reflexionado sobre formas en que las mujeres territorializan espacios a través de sus prácticas corporales, tomando como punto de inflexión la presencia del reggaetón y, precisamente, una revisión sobre las normatividades morales del que éste ha sido dotado. Proponemos comprenderlo dentro de estructuras y niveles de análisis que

23 Bey, Hakim, La zona temporalmente autónoma, 1991, p. 2, disponible en: https://lahaine.org/pensamiento/bey_taz.pdf.

24 Fuica, Inti y Vergara, Constansa, "Entramados de lo juvenil...", op. cit., p. 964 .

25 Urteaga, Maritza, La construcción juvenil de la realidad..., cit.

26 Pallarés, Joán y Feixa, Carles, "Espacios e itinerarios para el ocio juvenil nocturno”, Revista Estudios de Juventud, España, núm. 50, 2000, p. 32. 
van de lo micro (por ejemplo las prácticas del baile) a lo macro (referido a las estructuras sociales, culturales y económicas en las que se inscribe), dimensiones que, aunque se pueden analizar de forma independiente, no se separan una de la otra y que más bien juntas constituyen un tejido. Con esta propuesta nos alejamos de análisis simplistas que entienden el reggaetón como el principal productor de las representaciones de cosificación del cuerpo de las mujeres - desde una perspectiva objetual y/o desde la literalidad de sus letras-, sin considerar que éste no es más que un efecto sintomático de todo un sistema de imposiciones falogocéntricas.

No pretendemos desarrollar una apología de la fiesta; nos encontramos en el intento de dar una lectura compleja y situada desde una expresión tan espectacular como puede ser el baile, generando articulaciones con las distintas formas de socialidades y afectividades que pueden existir para las mujeres y para aquellas que se autoadscriben como lesbianas. "El ámbito de la socialidad refiere a la interacción social, el sentimiento y la experiencia compartida" 27 dado por un encuentro en la inversión del orden productivo.

El ocio festivo, ${ }^{28}$ como un intersticio que sigue el continuo de la idea de una autonomía temporal o, como señalan los autores, de una autonomía relativa, es un territorio clave para entender los cambios de la ciudad, las transformaciones y reterritorializaciones propuestas desde el baile y la música. Lo interesante es cómo este concepto es relevante no sólo como nodo central para dar lectura a partir del esfuerzo de generar claves de interpretación, sino también, como contexto en sí mismo, deviene clave interpretativa para leer cambios en relación con los modos de habitar la ciudad y de producir y crear territorios potenciales.

27 Urteaga, Maritza, La construcción juvenil de la realidad..., cit., p. 38.

28 Ganter, Rodrigo et al., "Trayectorias e inflexiones en el espacio de ocio festivo en la ciudad de Concepción-Chile", Revista Última Década, Santiago de Chile, núm. 46, 2017. 
Martínez-Noriega ${ }^{29}$ sostiene que la industria musical desempeña un papel fundamental en la generación de modelos de comportamiento, roles sexuales y diferencias de género. El reggaetón, desde tal perspectiva, es un claro ejemplo de esta mecánica, pues "ha contribuido a la construcción de nuevas colectividades y a formas de interacción en las que se estructuran y reproducen modelos de significación colectiva...: es un collage sociomusical". ${ }^{30}$ Sin embargo, según la autora, los efectos de este género musical urbano han sido asimétricos, desfavoreciendo, así, el rol de las mujeres, ya que en la lírica de sus canciones y en sus prácticas de baile, el llamado "perreo", "la mujer asume un rol pasivo y sumiso mientras que el hombre es quien porta el rol dominante y activo". 31

Nos proponemos cuestionar esta noción pensando en clave de relaciones de poder sin dotar de una moral particular el fenómeno dado por el baile. El excesivo relativismo tampoco nos permitiría ver estas configuraciones como posibilidades singulares donde nuestra experiencia en contextos en que este baile se da entre mujeres adopta otros significados y potencialidades, expresando, así, la posible ruptura de normatividades como un acontecimiento.

\section{GiERRE PRELIMINAR: ¿ATISBOS DE UNA POLÍTICA NOGTURNA?}

Santiago López-Petit ${ }^{32}$ denomina política nocturna a aquella que se distancia de la política clásica y que intenta construir una gramática de gestos radicales en su búsqueda del querer vivir compartido.

29 Martínez-Noriega, Dulce Asela, "Música, imagen y sexualidad: el reggaetón y las asimetrías de género", El Cotidiano, núm. 186, 2014.

30 Ibidem, p. 64.

31 Idem.

32 López-Petit, Santiago, Breve tratado para atacar la realidad, Buenos Aires, Tinta Limón, 2009. 
Querer vivir adquiere una dimensión política cuando el miedo o el cansancio se apoderan de nosotras, pues es entonces cuando vivir se transforma en una decisión, asevera López-Petit. Sin embargo, la vida que se decide es sacudida en su gesto radical poniendo entre paréntesis el tiempo, y muchas veces el gesto radical parece como un sinsentido desde la óptica del poder:

Una política nocturna es aquella que ha roto con las categorías políticas de la modernidad, especialmente con la noción de espacio político o espacio de aparición cuyo origen se remonta a la polis griega. En su lugar, la política nocturna emplea la secuencia interioridad común/fuerza del anonimato/espacios del anonimato. Su objetivo es que el malestar social se politice, que la fuerza del anonimato pueda llegar a expresarse. Pero esa expresión no debe confundirse con su representación. La fuerza del anonimato, por su propia esencia, rehuye y desfonda toda forma de representación. De esta manera, se inaugura una nueva política que persigue imponer una tierra de nadie, que intenta construir una gramática de gestos radicales. Una política nocturna que, porque no tiene horizonte, es imparable. ${ }^{33}$

$\mathrm{Al}$ introducir esta idea no pretendemos dar por sentado que las prácticas corporales con las que se territorializan los espacios del ocio festivo constituyan en sí mismas una panacea ni una comunidad política constituida. Es claro que la política de LópezPetit no acontece de forma privativa en la literalidad de la noche; sin embargo, la forma con la que ilustra esta política nos ofrece pistas para preguntarnos en qué medida y en cuáles contextos el baile puede llegar a ser un gesto radical.

Por otro lado, su interés por la fuerza del anonimato está relacionado con uno de los grandes problemas de Occidente: la disolución de las identidades y sus efectos en el horizonte político. Sin embargo, las mujeres, como señala Scott, ${ }^{34}$ hemos llegado a

\footnotetext{
33 Ibidem, p. 131.

34 Scott, Joan, op. cit.
} 
escena a partir de una historia ya contada, de un supuesto acaecido o esperado: unas veces hemos aparecido en el anonimato y otras más hemos sido perseguidas. Lo que queremos indicar es que apropiarnos del anonimato podría ser tanto como negar la deuda que la historia tiene con nuestro nombramiento y aparición. Es difícil pensar que el anonimato pueda ser una elección en un mundo que nos lo ha impuesto. Hay políticas que acontecen en la noche que nos interesan más: algo tan sencillo y complejo como salir del encierro propio de la domesticidad como el lugar conferido históricamente a las mujeres, atravesar las calles y la noche sin resguardarnos en el anonimato y, sobre todo, sin temor a que nos maten sólo por el hecho de ser mujeres.

La ciudad, como espacio creado y producido a partir de las afectividades y experiencias colectivas e individuales, se encuentra en el nodo central de procesos de reapropiación, despojos y recuperaciones que tienen sentido en la lógica global-local del sistema neoliberal. A partir de ello, no podemos dejar de atender y preguntarnos por dos procesos como la gentrificación y el consumo. ¿Cuáles son las distintas implicancias que tiene el desplazamiento de ciertas músicas desde la periferia hacia el centro? ¿A través de cuáles mecanismos opera el consumo de experiencias, emociones y afectos en el marco de un poder que nos dice debes desear el placer y que nos indica que debemos querer ser felices?

En suma, rescatar los diálogos entre nosotras — "pensar juntas", como diría Margarita Pisano - es una apuesta crucial para hacer de ésta y otras propuestas un espiral recursivo con sentido y anclajes en la historicidad de los procesos y la experiencia, en el acto de situarse y nombrarse y en dar contexto a la espectacularidad o la fascinación que pueden generar ciertos fenómenos y acontecimientos, como el baile, el ocio y la fiesta. Edda Gaviola ${ }^{35}$ reflexiona sobre - y a través de - la amistad entre mujeres. Nos propone "el abandono del juego de dominio y el descubrimien-

35 Gaviola, Edda, A nuestras amigas. Apuntes sobre la amistad política entre mujeres, México, Pensaré Cartoneras, 2016. 
to de otros contenidos del poder que hagan posible entrar en el reconocimiento a los saberes, en la reflexión inteligente y en la capacidad de respeto, desde las potencialidades y no desde las carencias humanas". ${ }^{36}$ Para nosotras la amistad entre mujeres guarda una relevancia política crucial y es, además del ocio festivo, uno de los más apremiantes territorios posibles por ocupar.

36 Ibidem, p. 24. 
Esta obra forma parte del acervo de la Biblioteca Jurídica Virtual del Instituto de Investigaciones Jurídicas de la UNAM www.juridicas.unam. $\mathrm{mx}$ https://biblio.juridicas.unam.mx/bjv

Libro completo en: https://goo.gl/sHxaH7

\section{IDENTIDADES TRANS}




\title{
ONTOPOLÍTICAS DEL CUERPO TRANS: CONTROVERSIA, HISTORIA E IDENTIDAD
}

\author{
Siobhan GUERRERO \\ Leah MUÑOZ
}

\begin{abstract}
SUMARIO: I. Una filosofia para pensar al cuerpo trans. II. Una historia ontológica del cuerpo trans. III. Ontología, actualidady controversia: el cuerpo trans deviniendo. IV. Bibliografia.
\end{abstract}

Nuestro objetivo en el presente ensayo es tripartito. Primero, buscamos construir un marco teórico para pensar la historia del cuerpo trans y lo que podríamos llamar, siguiendo a Annemarie Mol, la política ontológica de dicho cuerpo. En este sentido, avanzamos una lectura en términos de cuerpos, subjetividades e identidades radicalmente históricas, muy en el sentido de la ontología histórica de Ian Hacking, inspirada a su vez en los trabajos de Michel Foucault. Consideramos que esta radical historicidad implica concebir al cuerpo trans como resultado de diversas controversias - $\grave{a}$ la Latour - en las que participaron comunidades de médicos y legos y que gestaron tanto los discursos como las diversas culturas materiales que sirvieron de superficies de emergencia de dichas corporalidades. Segundo, buscamos esbozar la historia política de estas corporalidades y de las diversas condiciones de posibilidad que las han ido haciendo posibles, pero, de igual manera, que las han ido transformando, alejándolas de un discurso médico y acercándolas a un discurso centrado en la autonomía, el derecho y la identificación. Tercero, buscamos examinar cómo las controver- 
sias contemporáneas en torno al cuerpo trans implican una nueva transformación no únicamente de cómo se habita y piensa a dichos cuerpos, sino de cómo, en general, habitamos y pensamos los cuerpos, seamos sujetos cis o trans. Identificamos tres grupos de controversias actuales: el embate del feminismo trans excluyente, el debate en torno a infancias trans y, finalmente, el debate en favor de la despatologización.

\section{UNA FILOSOFÍA PARA PENSAR AL GUERPO TRANS}

El término ontopolítica o política ontológica fue acuñado por Annemarie Mol, ${ }^{1}$ etnógrafa holandesa especializada en temas de corporalidad y afamada contribuyente de la teoría del actor red (ANT), originalmente elaborada por Bruno Latour y John Law. Mol acuñó dicho término para hacer referencia a cómo el cuerpo no puede ser estudiado por medio de análisis que lo escindan, por un lado, en un soma biológico y causalmente estructurado, como lo entenderían la biología y la medicina o, por otro lado, en una suerte de superficie de inscripción infinitamente dúctil y sobre la cual operaría la cultura al moldearlo en función de imperativos y normas sociales desmaterializados e incorpóreos.

Precisamente el término política ontológica busca dejar en claro la inseparabilidad entre la ontología del cuerpo y los contextos sociales y políticos dentro de los cuales dicho cuerpo se encuentra situado. Mol, desde luego, no ha sido la única autora que ha sostenido tesis antidicotómicas a la hora de abordar al cuerpo como un objeto de estudio; importantes fenomenólogas feministas como Elizabeth Grosz ${ }^{2}$ o Gail Weis ${ }^{3}$ han realizado propues-

1 Mol, Annemarie, The Body Multiple: Ontology in Medical Practice, Durham, Duke University Press, 2002.

2 Grosz, E. A., Volatile Bodies: Toward a Corporeal Feminism, Indiana, Indiana University Press, 1994.

3 Weis, G., Body Images: Embodiment as Intercorporeality, Nueva York, Routledge, 2013. 
tas semejantes a través de su recuperación del término "imagen corporal", originalmente desarrollado por el psicoanálisis y luego retomado por filósofos como Merleau-Ponty.

Sin embargo, la novedad del trabajo de Annemarie Mol radica en la forma en la cual ella diagnostica una serie de sesgos acerca de cómo se ha estudiado al cuerpo para, posteriormente, hacer un abordaje que recupere el carácter objetual del cuerpo sin objetivar a los sujetos que son/habitan dichos cuerpos. Con respecto a lo primero, $\mathrm{Mol}$ ha señalado que el cuerpo ha solido estudiarse por medio de divisiones disciplinarias que precisamente lo escinden en términos de un cuerpo biológico y un cuerpo social. Por ejemplo, la biomedicina se ha ocupado tradicionalmente de estudiar las enfermedades, concebidas como disfunciones o desórdenes orgánicos, mientras que la sociología de la medicina más tradicional ha abordado los padecimientos en tanto las experiencias fenomenológicas que se experimentan al tener cierta enfermedad y que estarían cargadas de significados y metáforas socialmente mediadas.

Mol considera que estos abordajes son equivocados, pues, o bien sacrifican el carácter objetual, causalmente estructurado y material del propio cuerpo, o bien sacrifican las dimensiones fenomenológicas y culturales del mismo. Además, estas visiones dicotómicas suelen pasar por alto que el cuerpo adquiere ciertas lecturas en función de las prácticas que llevamos a cabo con él, en función de los contextos que nos engloban. Así, un cuerpo experimenta una limitación o una experiencia de goce en términos de las prácticas del contexto en que se localiza y no de una manera absoluta y ajena a cómo los sujetos se colocan en diversas relaciones sociales.

En cualquier caso, Mol acuña el concepto de ontonormas para hacer posible un análisis que dé cuenta de ambas dimensiones del cuerpo sin menoscabo de ninguna. Para señalar que el cuerpo es, a la vez, bioquímica, biomecánica, fisiología, ontogenia, anatomía o morfología, pero también la herramienta de trabajo más fundamental, el sitio de placer por antonomasia o el asiento de 
los dolores. Es decir, el cuerpo es a una misma vez objetual-material y semiótico-normativo. Hay cuerpos que se juzgan sanos o enfermos, hegemónicos o abyectos, naturales o contra-natura. $\mathrm{Y}$ esos aspectos, sostiene Mol, no pueden pensarse sin atender a una misma vez las cargas normativas inscritas en el cuerpo y las instancias materiales o arreglos que son tomados como los dominios de aplicación de dichas normas.

Ahora bien, esta concepción del cuerpo nos importa porque en este ensayo buscamos justamente abordar un tipo concreto de cuerpo: el cuerpo trans. Nos interesa reflexionar acerca de las condiciones históricas en las cuales emerge dicha corporalidad, prestando especial atención a los discursos que lo han moldeado, a los agentes que fueron fundamentales en su constitución - las propias personas trans, en conjunción con médicos, sexólogos, psiquiatras, endocrinólogos, pero también activistas e incluso detractores del propio cuerpo trans-, a las culturas simbólicas y materiales que le han hecho posible desde espacios de emergencia como el derecho, la medicina y la prostética, a las controversias que lo han ido y lo siguen conformando, controversias etiológicas, psiquiátricas, sexológicas, jurídicas, filosóficas, e incluso feministas.

Entendemos al cuerpo trans y al sujeto trans como radicalmente históricos, como ejemplos de ontologías históricas en el sentido de Ian Hacking. ${ }^{4}$ Ontologías y no epistemologías porque no consideramos que la sexualidad, ni en los aspectos relacionados con el deseo ni en aquellos relacionados con la corporalidad, la identidad y la orientación, remitan a naturalezas humanas transhistóricas. No creemos en la panculturalidad de la homosexualidad o de la transexualidad, pero tampoco de la heterosexualidad o cisgeneridad. No creemos que el aparato psíquico del sujeto sea históricamente invariante y que simplemente hayan cambiado las formas en las cuales éste se representa o se describe. Tampoco

4 Hacking, I., "Historical Ontology", In the Scope of Logic, Methodology and Philosophy of Science, Ámsterdam, Springer Netherlands, 2002, pp. 583-600. 
creemos en corporalidades estables a través de los devenires de las culturas.

No creemos en ninguna de estas tesis porque, como ha hecho ver Paul Preciado, ${ }^{5}$ el cuerpo trans en concreto está atado a contextos tecnológicos específicos con el surgimiento de la endocrinología, de la síntesis de hormonas, pero también a contextos propios de una psiquiatría y sexología que se encontraron con un sexo psicológico que no podía fundarse, reducirse o rastrearse a las diversas modalidades orgánicas del cuerpo sexuado, sean éstas los cromosomas, los niveles hormonales, los genitales, los gametos, etcétera. Pero no es ésta la historia de un cuerpo determinado por la tecnología, ya que aquí también fueron irrumpiendo nuevas formas de ir entendiendo al hecho mismo de estar sexuados y sexuadas dentro de un cuerpo social que otorga posiciones en función de este aparente factum y que tienen que ver con la historia de los feminismos y cómo éstos hicieron posible pensar al sexo social como algo que tampoco podía colapsarse en anatomía.

Yendo aún más lejos, consideramos que no es defendible una mirada transhistórica o pancultural del cuerpo, de la subjetividad, de la identidad o del deseo, porque ello requiere llevar a cabo una radical escisión entre el cuerpo como soma y el cuerpo fenomenológicamente habitado, mediado en su propia relación consigo mismo por imperativos sociales situados. Justo esta escisión es la que resiste Mol, esta escisión entre un soma biológicamente caracterizable y presuntamente común a toda la humanidad, como si el tiempo evolutivo se hubiera acabado con el advenimiento de la cultura, como si hubiésemos dejado de coconstruirnos mientras construíamos nichos en hábitats variables. No, ni el soma mismo admite ser pensado de forma transhistórica; no es éste una base común a toda la humanidad, pues particulares han sido también nuestras relaciones ecológicas, alimentarias y simbióticas.

5 Preciado, P., Manifiesto contra-sexual: prácticas subversivas de identidad sexual, Madrid, Pensamiento Opera Prima, 2002. 
Así pues, los esfuerzos de transhistorizar al sujeto y al cuerpo suelen fundarse en un biologicismo que, primero, nos separa entre un soma orgánico y un revestimiento cultural de poca profundidad para, después, rastrear a esa base orgánica un listado de atributos que queremos presentar como naturales y sempiternos. ${ }^{6}$ Pero si esta escisión es imposible, como defiende Mol, y si, además, el propio soma es también radicalmente histórico, modificado siempre por su carácter material, entonces no está disponible este sendero a la eternización de rasgo alguno.

Y tampoco estará disponible la apuesta análoga que asume que un mecanismo general de constitución de un sujeto a nivel psíquico, como lo ha hecho en gran medida cierto psicoanálisis, es el camino hacia esa postulación de un sujeto transhistórico. Aquí de nuevo se postulan pulsiones que anteceden a todo revestimiento cultural o dinámicas estructurales presuntamente panculturales. Marcuse ${ }^{7}$ ha sido ya muy enfático en la historización de dichas pulsiones y su maleabilidad al interior del capitalismo. Pero si de lo que se trata es de explicar identidades y deseos categorialmente acotados, entonces no podemos perder de vista el anclaje semiótico de identificarse y desear un anclaje abierto a los devenires del lenguaje y la simbolización. Al no haber simbolizaciones transhistóricas no puede haber actos categorialmente acotados y con anclaje semiótico que puedan ser transhistóricos.

Lo anterior se traduce en que, así como los paidika griegos no son los gays modernos, ${ }^{8}$ ya que a la primera categoría la estructura un homoerotismo cruzado por eje de la edad, la enseñanza y la ciudadanía, elementos ausentes en la segunda, así tampoco son los cuerpos transexuales/transgéneros los mismos cuerpos de las

6 Mc Manus, F., "The Structure of Explanations and Counter-Explanations of Homosexuality", The Open fournal of Philosophy, 2(4), 2012, pp. 235-243.

7 Marcuse, H., Eros and Civilization: A Philosophical Inquiry into Freud, Nueva York, Beacon Press, 2015.

8 Guerrero McManus, F., ¿'Naces o te haces? La ciencia detrás de la homosexualidad, México, Paidós, 2013. 
muxe o de sujetos que históricamente no se alinearon con el binario. En el primer caso, el sujeto de deseo no se construye como un hombre sino como un efebo, de allí la historicidad radical de una categoría que estructura un deseo. En el segundo, no sólo se dispone de tecnologías diferentes o herramientas jurídicas antes ausentes, sino de un aparato categorial que ha tomado distancia del lema de que la anatomía es destino y ha comenzado a pensar la posibilidad de devenir hombre desde un cuerpo femenino o devenir mujer desde un cuerpo masculino. Aquí hay, por supuesto, una innovación histórica en las formas de ser sujeto que no admite transhistorización alguna.

Todo lo anterior nos conduce, por ende, a un compromiso radical con la historicidad ontológica del cuerpo trans, de la identidad trans, de su misma materialidad. Entendemos así al cuerpo como materia organizada históricamente organizada. Una historicidad donde se conjugan tres tiempos: el evolutivoecológico del soma; el cultural, que versa sobre cómo se constituye un cuerpo sexuado en sociedad y, desde luego, el biográfico. Pensamos también en una organización que remite a una materialidad somática-orgánica pero también propia de un cuerpo que labora, embebido en relaciones de producción, distribución y consumo, embebido en dinámicas que lo posicionan en una clase, género, raza o etnia; por último, pensamos en esa materialidad fenomenológica del cuerpo que se habita, que se habita y se vive distinto no sólo en función de una diferencia sexual, sino también atendiendo a diferencias étnicas o raciales, e incluso en términos de nuestra propia diversidad funcional.

Este cuerpo, por tanto, no puede ser comprendido si no rastreamos sus superficies de emergencia, conformadas por discursos, disciplinas y espacios científicos, médicos y políticos. Su comprensión remite a entender los procesos sociales que lo inscriben con significados particulares o que conllevan la incorporación de tecnologías prostéticas o neohumorales que lo transforman. Estos conceptos, inscripcionalidad e incorporación, han sido ya 
trabajados por filósofos como Derrida ${ }^{9}$ o Butler, ${ }^{10}$ en el primer caso, o por Haraway ${ }^{11}$ y Preciado, ${ }^{12}$ en el segundo.

En ese sentido, el cuerpo trans lleva las marcas inscritas en él por una historia de patologización y abyección. Pero también por su fetichización, exotización y objetivación como un cuerpo consumible, no sólo en tanto producto o mercancía sino como un cuerpo descartable. Está, desde luego, cruzado por los simbolismos del género, que se inscribe en él para resistir la identidad de género de quien lo habita, por un lado, y para expresar esa misma identidad, por otro. Y este punto nos lleva de la inscripcionalidad a la incorporación, en la cual la medicación tecnológica, sea prostética o neohumoral, se vuelve central. Las prótesis no remiten siempre a aceites, silicones o biopolímeros; también la ropa es prostética y sirve a una función de generizar. Y las tecnologías neohumorales de las intervenciones hormonales, que no todo cuerpo trans instancia, son otro vehículo de incorporación. Hay que decir, finalmente, que una dinámica más sería la desincorporación literal o figurada de partes del cuerpo que se eliminan de la imagen corporal psíquica y social.

Estos mecanismos, desde luego, son ellos mismos históricos y se gestaron a la luz de discursos, disciplinas y espacios de emergencia específicos. Su historicidad está atada a la historicidad del propio cuerpo trans. Y también refleja el último punto de este marco analítico que hemos introducido para poder así narrar una historia ontológica del cuerpo trans. Nos referimos aquí al ámbito de las controversias en esa acepción latouriana que remite a cómo se constituye un hecho científico.

9 Derrida, J., Specters of Marx: The State of the Debt, the Work of Mourning and the New International, Nueva York, Routledge, 2012.

10 Butler, J., Bodies that Matter: On the Discursive Limits of Sex, Nueva York, Taylor \& Francis, 2011.

11 Haraway, D., Simians, Cyborgs, and Women: The Reinvention of Nature, Nueva York, Routledge, 2013.

12 Preciado, P., op. cit. 
Si Foucault ${ }^{13}$ describió a la nueva ciencia del sexo como conformada dentro del eje subjetividad-deseo-verdad, entonces cabe la pregunta de cómo se van conformando las verdades de esos cuerpos. Foucault ofreció una serie de metodologías arqueo-genealógicas que reconocemos como valiosas pero que buscamos completar por medio de la noción de controversia ${ }^{14}$ para señalar cómo diversas redes de actantes, esto es, de agentes humanos y no humanos, configuran posiciones encontradas que apoyan o debilitan la posibilidad de juzgar algo como un hecho.

Allí no sólo median las reticencias conservadoras de quienes defienden miradas transhistóricas y biologicistas (o religiosas) de los sexos y los géneros o de quienes buscan legitimar identidades al hacerlas sempiternas. Allí también se juega el rol causal-material de un sexo somático, un sexo pensado como la forma en la cual se estructura causalmente un cuerpo a lo largo de su ontogenia y en torno a sus funciones reproductivas y socio-sexuales, un rol en el cual las hormonas, la genitalidad o la anatomía podrían o no haber determinado al sexo psíquico. ${ }^{15}$ La controversia implica reconocer esto como una posibilidad histórica que se decantó de una forma que hoy no admite reduccionismos.

Por último, la controversia remite a las relaciones entre médicos y sujetos que se presentan como lo que hoy leeríamos como personas trans; médicos que, por un lado, buscarán reclutar elementos psicológicos, fisiológicos o anatómicos para explicar e intervenir a estos sujetos. Sujetos que, por otro lado, buscan reclutar la experticia médica en función de su realización personal. Así, la controversia ilumina cómo interactúan las agencias materiales y discursivas de humanos, moléculas, órganos, estructuras

13 Foucault, M., The History of Sexuality: An Introduction, Nueva York, Vintage, 1990.

14 Latour, B., "On Actor-Network Theory: A Few Clarifications", Soziale Welt, 1996, pp. 369-381; Harman, G., Prince of Networks: Bruno Latour and Metaphysics, Londres, re-Press, 2010.

15 Freeman, S. K. y Meyerowitz, J., How Sex Changed: A History of Transsexuality in the United States, Cambridge, Harvard University Press, 2004. 
sociales y demás en la producción de hechos que abren o cierran caminos ante ciertas formas de subjetividad y corporalidad.

Ésta es, pues, nuestra apuesta analítica. Un cuerpo histórico, no escindible, no sobredeterminado ni tampoco infinitamente dúctil. A la luz de esto, habremos de intentar, en la próxima sección, narrar su historia ontológica para, posteriormente, cerrar con las tres controversias mencionadas al inicio.

\section{UNA HISTORIA ONTOLÓGICA DEL CUERPO TRANS}

Trazar la historia del cuerpo trans es trazar la historia política de un cuerpo que emergió por múltiples actores, conocimientos y tecnologías en contextos situados. No es una historia que busque marcar una determinación fundamental que encorsete de una vez y para siempre lo que debe ser este cuerpo. Tampoco es una historia que haga del cuerpo trans un producto nacionalista. Por el contrario, es la historia de un cuerpo que se reclama multinacional, que ha ido de lo local a lo global, producto de la globalización del conocimiento con el transporte de los modelos sexuales médicos hegemónicos del capitalismo luego de la segunda posguerra, pero también con el transporte y apropiación de distintos discursos activistas y feministas por parte de las personas trans. Es la historia de la construcción de significados y tecnologías ${ }^{16}$ en un cuerpo en movimiento, en el devenir de la lucha política de aquellos que lo encarnan.

\section{El siglo XIX y los sexólogos}

Podemos esbozar los orígenes del cuerpo trans en los inicios del siglo XX con el surgimiento de la categoría "transexualidad"; sin embargo, es necesario voltear un poco más atrás para enten-

\footnotetext{
16 Haraway, D., op. cit.
} 
der porqué la transexualidad surgió como una categoría médica que hacía referencia a una patología sexual.

A finales del siglo XVII, en occidente se fue construyendo en el imaginario social una "verdad sobre el sexo" a través de una expansión de discursos que delineaban la sexualidad normal y patológica. En este contexto se definen las "desviaciones sexuales" y surgen categorías como "homosexual". Sin embargo, es hasta finales del siglo XIX que se encuentran en la medicina las primeras referencias a lo trans en los trabajos del psiquiatra Krafft-Ebing en 1877. Él hacía referencia a un tipo específico de homosexuales que sufrían de "metamorfosis sexualis paranoica" y se identifican fuertemente con el sexo opuesto queriendo modificar sus características sexuales. ${ }^{17}$

Es en los inicios del siglo XX que los sexólogos Magnus Hirschfeld y Havelock Ellis separaron la homosexualidad y catalogaron otro tipo de experiencias bajo el término de "travestismo", que no sólo incluía identificación con el género opuesto sino también el portar la ropa del otro género. ${ }^{18}$

Aunque la categoría "transexual" y "transexualismo" surgieron décadas más tarde, las conceptualizaciones de cambio de sexo y cirugía de cambio de sexo, fuertemente asociadas a estas categorías, existían ya desde antes gracias a las experimentaciones en los campos de la fisiología. En 1910, en Austria, el médico fisiólogo de la Universidad de Viena Eugen Steinach fue el primero en incursionar en los cambios de sexo en animales de laboratorio para más tarde llevar esos conocimientos y prácticas al Instituto para la Ciencia Sexual de Magnus Hirschfeld, que se encargó de publicitar y llevar a cabo cirugías de cambio de sexo a pacientes que etiquetaban de "transvestis".

Los estudios de Steinach, que se basaban en trasplantes de gónadas entre sexos, no solamente atribuían el sexo, el género y la sexualidad a las secreciones de las gónadas, sino que además

17 Pons, A. y Garosi, E., “Trans”, en Alcántara, Eva y Moreno, Hortensia, Conceptos clave en los estudios de género, México, UNAM-PUEG, 2016.

18 Freeman, S. K. y Meyerowitz, J., op. cit. 
iban configurando la posibilidad médica de transformar el sexo de los animales.

En 1923 Magnus Hirschfeld publicó un artículo en el cual usaba el término seelischen Transsexualismus (transexualismo del alma), que asociaba a los invertidos. Luego de visitar en Viena a Steinach divulgó sus trabajos y en 1920 comenzó a organizar las primeras cirugías de cambio de sexo en Europa.

La transexualidad moderna emergió en un contexto en donde el aparato tecnológico médico después de la Segunda Guerra Mundial posibilitó la intervención del cuerpo de una forma cada vez más especializada al permitir llevar a cabo cada vez mejores cirugías de cambio de sexo (vaginoplastia y faloplastia), cirugías plásticas y tratamientos hormonales, es decir, la tecnología posibilitó nuevas corporalidades y subjetividades. ${ }^{19}$ Sin embargo, reducir la emergencia de la transexualidad a un determinismo tecnológico es pasar por alto que en distintas partes del mundo, antes de que emergiera la transexualidad moderna con sus propios protocolos médicos y tecnológicos, existían tecnologías con las que el cuerpo se intervenía (que de hecho eran las que permitían las cirugías de cambio de sexo en Europa), en donde se removía el aparato reproductor, gónadas y pechos enfermos o dañados, y se hacían trasplantes de gónadas o se utilizaban extractos de hormonas. ${ }^{20}$

La tecnología por sí misma no posibilitó la transexualidad, fue necesario un reencauzamiento de las tecnologías sobre la base de distintas concepciones acerca del sexo, el cuerpo y las libertades sexuales. En Alemania, donde comenzaron los cambios de sexo, el propio Magnus Hirschfeld era parte de un movimiento político para remover los obstáculos legales y médicos que impedían a homosexuales y transvestis vivir su sexualidad.

A finales del siglo XIX e inicios del siglo XX las concepciones sobre el sexo comenzaron a moverse. Surgió la teoría de naturale-

19 Preciado, P., Testo Yonki, Barcelona, Huertas, 2008.

20 Freeman, S. K. y Meyerowitz, J., op. cit. 
za humana bisexual, del filósofo austriaco Otto Wininger y Magnus Hirschfeld, en la que decían que existen gradaciones internas que llevarían al hermafroditismo o a otras formas atenuadas que entrarían dentro de la normalidad. Esta teoría sirvió al sexólogo británico Havelock Ellis para decir que la bisexualidad humana podía proveer las bases biológicas del travestismo en donde figuraban predisposiciones anatómicas e influencias hormonales.

En esta nueva concepción del sexo es que el recién nacido campo de la endocrinología innovaría en dejar en segundo plano a las gónadas como determinantes del "sexo verdadero" y en colocar a las hormonas como los nuevos marcadores del sexo. Tampoco los genitales ni el aparato reproductor ni los más tarde descubiertos cromosomas, ocupaban el mismo plano que las hormonas.

Steinach creía que la línea entre los sexos no era tan clara y que las hormonas pueden inhibir las características sexuales dominantes de un organismo y estimular las características sexuales latentes. Las décadas de los años veinte y treinta fueron de gran descubrimiento para la endocrinología, ya que el encontrar ambas hormonas en ambos sexos apoyaría la noción de que los sexos son más parecidos que opuestos. El concepto de cambio de sexo tenía sus bases así en la teoría de la bisexualidad humana.

\section{Harry Benjamin, Robert Stoller y fohn Money}

La transexualidad moderna está sostenida en las aportaciones de Harry Benjamin, Robert J. Stoller y John Money. Tres figuras clave dentro de la medicina y psicología en la segunda mitad del siglo XX que construyeron la transexualidad.

En 1949 aparece por primera vez el término "transexual" en el artículo "Psychopathia Transexualis" de David Cauldwell, haciendo referencia a los sujetos que deseaban cambiar su sexo. Cauldwell se oponía a realizar cirugías a los pacientes que pedían cambio de sexo. 
Es Harry Benjamin en Estados Unidos quien, venido de la tradición de la ciencia sexual alemana, se opone al establishment médico estadounidense (más fuertemente anclado en un entendimiento de la transexualidad como psicopatología) y comienza a dar tratamientos hormonales a pacientes transexuales en vez de intentar curarlos psicoterapéuticamente. Justo como lo pensaba la ciencia alemana, él creía que los transexuales tenían una causa somática; de hecho, Benjamin, en 1949, comienza con la idea del cuerpo equivocado al señalarle a una de sus pacientes que él la consideraba "una mujer que accidentalmente poseía el cuerpo de un hombre". Esta idea de una disociación entre cuerpo y mente la tomó de Karl Heinrich Ulrichs, quien en 1860 había establecido el concepto de "alma de mujer en el cuerpo de hombre".

Este supuesto malestar por una disociación entre mente y cuerpo ha acompañado el entendimiento de la experiencia trans desde su concepción hasta nuestras fechas, como lo expresa el término disforia de género.

En 1940 surge la categoría de "sexo psicológico" para explicar la pertenencia de los pacientes a ser hombres o mujeres en el caso de la intersexualidad. Los médicos consideraban que el sexo psicológico estaba fuertemente anclado y, si era social o biológico, era difícil modificarlo. Más tarde, esta categoría se trasladó a los pacientes transexuales y fortaleció las intervenciones médicas frente a las intervenciones psicoterapéuticas.

En la década de 1950, John Money y sus colaboradores, negando los enfoques psicoanalíticos y los modelos biológicos, acuñaron la categoría de "género" para explicar las influencias ambientales que generaban el sexo psicológico de los intersexuales, originando explicaciones de corte social.

En 1964, el psiquiatra Robert J. Stoller, basándose en el término de género, acuñó la categoría "identidad de género" para hacer referencia al sentido propio de pertenecer a un sexo particular. A diferencia de la categoría "rol de género", identidad de género hacía referencia a un sentido subjetivo del yo y no propia- 
mente a comportamientos masculinos o femeninos. Stoller tenía una etiología sobre la transexualidad más de corte psicodinámica que biológica o social.

Harry Benjamin, en 1966, hace público su texto The Transsexual Phenomenon, en donde describe que el sujeto transexual es quien desea vivir física, sexual y mentalmente como si fuera del otro sexo. Apoyándose en estas teorizaciones sobre la identidad de género defiende su modelo de tratamiento hormonal y quirúrgico para los transexuales.

Tanto Benjamin como Money y Stoller, herederos de la teoría sobre la bisexualidad humana, compartían una visión del sexo como algo que podía ser modificado con las tecnologías hormonales y en donde los aspectos cromosómicos no ocupaban la parte determinante. Benjamin separó el sexo en siete partes: cromosómico, genético, anatómico, legal, gonadal, germinal, endócrino, psicológico y social (crianza sexual), y dentro de esto reconoció que algunos aspectos, como lo anatómico y lo hormonal, nunca eran enteramente de machos o hembras y que incluso podían modificarse. ${ }^{21}$

\section{La década de 1980: patologización del cuerpo trans}

A partir de la década de 1980 la transexualidad aparece ya oficialmente patologizada dentro del Manual diagnóstico y estadístico de trastornos mentales de la Asociación Americana de Psiquiatría, una de las instituciones médicas más poderosas a nivel mundial.

El diagnóstico de "transexualismo" aparece por primera vez en el DSM-III, definido como "un trastorno en la esfera sexual que se caracteriza por un persistente malestar en el sexo asignado y una constante preocupación por modificar las características sexuales primarias y secundarias, adquiriendo las del otro sexo, a través de tratamientos hormonales y quirúrgicos". ${ }^{22}$

21 Freeman, S. K. y Meyerowitz, J., op. cit.

22 Pons, A. y Garossi, E., op. cit. 
En la década de 1990 la categoría de transexualismo es sustituida por la de "trastorno de identidad de género" en los manuales internacionales de patologías mentales de la APA y la OMS: DSM-IV y CIE-1 (Clasificación Internacional de Enfermedades), respectivamente

En 2013 ocurrió la última modificación a la versión $\mathrm{V}$ del DSM, en donde la categoría de "trastorno de identidad de género" es cambiada por la de "desorden de disforia de género", sin modificar de forma sustancial la patologización existente.

\section{El activismo trans}

Luego de que en los años sesenta fuera quedando más claro el modelo médico sobre la transexualidad, comenzó a surgir en esa misma década un activismo transexual que se informaba sobre los enfoques médicos y veía posible la transformación corporal.

Las primeras militancias transexuales demandaban la cirugía de cambio de sexo como parte de una búsqueda de autenticidad, además de que se criticaban los modelos médicos de la transexualidad que la presentaban como una enfermedad o un desorden. Lo anterior ligado a la lucha en contra de la discriminación y los riesgos que vivían en el acoso cotidiano tanto por la policía como por la transfobia.

Mucho del discurso de las organizaciones activistas transexuales estaba influido por el discurso de los derechos civiles, que tenía un correlato en otras luchas sociales en ese momento.

Este incipiente movimiento transexual, unido a distintas expresiones artísticas, fue lo que llevó a configurar a finales de los años sesenta e inicios de los años setenta una contracultura más claramente definida. En esta contracultura surge la "segunda ola" del movimiento transexual, que tenía un cuestionamiento más claro hacia la autoridad médica y abogaba por la despatologización. A la par de la lucha contra el poder médico, desde 
los años sesenta también existían esfuerzos de las personas transexuales para intervenir en el terreno legal y cambiar su sexo y nombre.

En los años setenta surge el concepto de transgénero, acuñado por Virginia Prince como una alternativa a las categorías de travesti y transexual, ya que para ella ser transgénero era vivirse plenamente como el otro género sin necesidad de recurrir a las cirugías de reasignación genital de la medicina que comenzaron a ser normativas.

Es en los años noventa que tanto activistas como académicas transgénero en Estados Unidos, como Sandy Stone y Leslie Feinberg, acuñaron el término transgénero como un término paraguas para distintas experiencias que cuestionaban el binarismo de género que promovía la medicina, a la par que se hacía una crítica a conceptos esencialistas del género y se comenzaba así un discurso crítico de lo trans sobre el sexo y el género, que más tarde se uniría al feminismo.

En 2010, en Europa, surge la campaña Stop Trans Pathologization 2012 que busca despatologizar las distintas formas de ser trans, reconociendo la pluralidad de vivir el género tal y como hombres y mujeres lo hacen.

\section{ONTOLOGÍA, ACTUALIDAD Y GONTROVERSIA: EL CUERPO TRANS DEVINIENDO}

La emergencia plena de un sujeto y una corporalidad trans a mediados del siglo pasado no representa, como ya hemos visto, el fin de la historia ontológica del cuerpo trans. Este cuerpo y la subjetividad que le acompaña continúan en transformación, y en esta última sección queremos atender precisamente las controversias que hoy en día informan a esta ontología.

Sin embargo, es menester aclarar que este constante devenir no es privativo del cuerpo trans. La radical apertura e historicidad, no únicamente de las identidades sino también de las subjetividades y corporalidades, es algo que ha sido ya descrito 
por feministas de la tercera ola. ${ }^{23}$ Es importante aclarar este punto para enfatizar que todo cuerpo y toda subjetividad experimentan hoy en día fuertes cambios. La llegada de los discursos post-humanistas y de las ontologías cyborg son ejemplos de esta percatación acerca de la radical transformación - que no deshumanización - de las viejas lógicas modernas en torno al cuerpo y el sujeto. ${ }^{24}$

Sea como fuere, nos parece que hoy en día hay tres controversias que cruzan al cuerpo y el sujeto trans y que son nuevos ejes para su constitución. Tenemos en mente al embate del feminismo trans-excluyente (TERF, por sus siglas en inglés), el tema de las infancias trans y, por último, el tema mismo de la despatologización. En estos tres casos figuran espacios de emergencia conformados por discursos, tecnologías y actores inmersos en controversias tanto acerca del lugar social y político que deben ocupar los sujetos trans como sobre la propia coherencia e inteligibilidad de dicho cuerpo.

Con respecto al primer punto, identificamos la obra de Janice Raymond ${ }^{25}$ como un punto de quiebre que inauguró una serie de discursos en torno al sujeto trans, que simplemente no le dan cabida al interior del feminismo pero que además colocan, tanto a hombres como a mujeres trans, en calidad de sujetos sospechosos al describirlos, respectivamente, como lesbianas que han buscado los privilegios de la masculinidad, o eunucos al servicio del patriarcado que irrumpen en espacios de mujeres para desarticular sus luchas. Estas posiciones implican que el feminismo transexcluyente dibuja al sujeto político del feminismo de una manera especialmente rígida, atándolo al sexo biológico, entendido como una suerte de universal natural y transhistórico, y ejerciendo la escisión criticada al comienzo de este texto.

23 Haraway, D., op. cit.; Braidotti, R., Feminismo, diferencia sexual y subjetividad nómade, Madrid, Gedisa, 2015.

24 Hayles, N. K., How We Became Posthuman: Virtual Bodies in Cybernetics, Literature, and Informatics, Chicago, University of Chicago Press, 2008.

25 Raymond, J. G., The Transsexual Empire, Nueva York, Beacon Press, 1980. 
El movimiento TERF, en cualquier caso, se alimenta de lecturas simplistas del feminismo de la diferencia, ya que éste colocó en el centro de su reflexión no a la categoría de género sino a la noción misma de diferencia sexual como nodo articulador; este último concepto es entendido aquí como la simbolización psíquica de las diferencias sexuales somáticas y de las vivencias fenomenológicas que les vienen asociadas. ${ }^{26}$ Sin embargo, este movimiento ignora que desde los feminismos de color y de la diversidad funcional se hizo un fuerte llamado de atención al señalar que no hay una única vivencia fenomenológica de lo femenino, y que la simbolización psíquica tampoco es unívoca. ${ }^{27}$ De allí que no posean argumentos legítimos para trazar una frontera entre las mujeres cis y las mujeres trans.

Como sea, este feminismo trans-excluyente ha cuestionado la idea misma de "identidad de género", considerándola vacía y carente de referente alguno; con ello, han buscado hacer imposible o inviable al sujeto trans. Han, así también, acusado a los sujetos trans de fomentar visiones esencialistas e innatistas del género al presentarse como personas que siempre fueron hombres o mujeres. Estas acusaciones han abierto un fuerte debate que dista mucho de estar resuelto pero que ha llevado a resaltar que hay muchas variedades de cuerpos trans y que no todos caen dentro de un binario, pero que aquellos que así lo desean no deben ser considerados especialmente perniciosos, pues no es responsabilidad del sujeto trans el fungir como vanguardia en la lucha contra el binarismo. De igual manera, ha sido necesario reiterar la legitimidad de la noción de identidad de género pero no ya pensada como una suerte de hecho psicológico dado por una biología misteriosa, sino como una suerte de punto de coherencia o integración de la agencia práctica de los sujetos que se

26 Un triste ejemplo de cómo el feminismo de la diferencia puede conllevar descalificaciones del cuerpo trans lo encontramos en Grosz, op. cit.

27 Weis, G., op. cit.; Campbell, F., Contours of Ableism: The Production of Disability and Abledness, Nueva York, Springer, 2009. 
viven y presentan a sí mismos como ocupando posiciones generizadas que les permiten navegar por el mundo.

Un último punto que vale la pena mencionar y que nos enlazará con el segundo aspecto que deseamos discutir en esta sección - la infancia trans - es su sostenido rechazo a aceptar la posibilidad de que puedan existir niños, niñas y adolescentes trans. Para muchas feministas TERF la transexualidad implica una suerte de disciplinamiento heterosexualizante de niños y niñas homosexuales que se ven intervenidos para restaurar una heterosexualidad hipercompulsiva. ${ }^{28}$ Nótese que aquí también las feministas TERF presuponen la naturalidad de la homosexualidad como algo dado y ajeno a un devenir ontogenético e histórico, de nuevo escinden al cuerpo entre soma y cultura, y es por ello que consideran que la transexualidad es una suerte de mecanismo cultural disciplinario y patriarcal que atenta contra una orientación sexual supuestamente natural.

De lo anterior extraen una comparación entre las infancias trans y los movimientos eugenésicos de comienzos del siglo XX, diciendo que dichas tecnologías atentan contra los derechos reproductivos de niños y niñas homosexuales, castrándolos de facto. Lo que desde luego no comprenden estas voces es la posibilidad genuina de que durante la ontogenia el sujeto negocie una posición tal que se consolide una imagen de sí mismo no a través de la identificación con una subjetividad homosexual, sino a través de la identificación con una subjetividad/corporalidad trans.

Entrando, ahora sí, de lleno al punto de las infancias queremos simplemente señalar que la idea misma de la posibilidad de niños, niñas y adolescentes transexuales o transgénero extiende el alcance biográfico de la percatación de que no se habita el cuerpo por medio del género que se quisiera, y extiende así también el alcance ontogenético de la noción de transición de género, llevándolo incluso a momentos muy tempranos de la vida. Esto es

28 Jeffreys, S., "The Transgendering of Children: Gender Eugenics", Women's Studies International Forum, 35(5), 2012, pp. 384-393. 
una ruptura con las figuras de la transexualidad que observamos durante el siglo XX, en parte porque inaugura un nuevo espacio de reflexión acerca de si los menores son sujetos epistémicos competentes en lo que respecta a su autoconocimiento - sus creencias de se - en lo que se refiere a su identidad de género. ${ }^{29}$ $\mathrm{Y}$ en parte porque ese debate implica la transformación de los marcos legales y médicos que harán posible dichos tránsitos al enfatizar el derecho de los menores a participar en la decisión más importante de sus vidas: responder a las preguntas de quiénes son y quiénes quieren ser.

En cualquier caso, la posibilidad de hablar de infancias trans parece alimentar narrativas transnatalistas, es decir, narrativas biográficas en las cuales la condición trans es innata, fija e inmodificable. Si ello es el caso, tal pareciera que este rasgo habrá de expresarse muy pronto en la vida y que sería no sólo inmutable, sino una suerte de invarianza a través de la historia de vida. Sin embargo, en esta controversia ha quedado claro que hay experiencias trans evanescentes de niños, niñas, adolescentes e incluso adultos, que tienen etapas en las que se identifican como personas trans para luego dejar de hacerlo. Hoy en día es menester reconocer que estas experiencias existen y que resignifican la oposición misma cis/trans como una suerte de corte ontológico insalvable e inamovible. Ello implica reconocer que no debemos abordar las experiencias trans dentro de un marco epistemológico que pretenda rastrear estas mencionadas y presuntas invarianzas biográficas, porque el género es mucho más fluido que eso.

Finalmente, para cerrar este texto, así como con las infancias se hace una apelación a los derechos para dar cuenta de la necesidad de transformar una vez más al sujeto trans para dejar de

29 Guerrero McManus, F. y Muñoz Contreras, L., Epistemologías transfeministas e identidad de género en la infancia: del esencialismo al sujeto del saber, manuscrito sin publicar; Alcántara, E., "Niñas y niños: el derecho a existir sin diagnóstico", Derecho a la identidad de género de niñas, niños y adolescentes, México, Tribunal Superior de Justicia-Consejo de la Judicatura de la Ciudad de México, 2016, pp. $111-134$. 
pensarlo desde la tutela médica y empezar a pensarlo desde una autonomía epistémica en la cual se conoce y se decide sobre la propia vida, así también se gesta hoy en día un movimiento en favor de la despatologización para el grueso de los cuerpos trans. Consideramos que esta controversia es la tercera que hoy en día transforma la ontología del cuerpo trans.

No ahondaremos en los detalles de este punto, pues María Fernanda López López (en este volumen) dedica un ensayo específicamente al tema de la despatologización del cuerpo trans. Basta decir simplemente que ésta es una transformación mayúscula, pues implica que la lógica misma del cuerpo trans ya no se asienta en una patologización que asume un malestar psíquico con respecto al propio cuerpo - las famosas dismorfia y disforia de género- como fundante del sujeto trans. Tampoco asume que es patológica o incongruente la condición misma de que el sexo del soma no se alinee con la identidad de género y que la salud psíquica demande o imponga la necesidad de restaurar dicha alineación.

Por el contrario, el sujeto trans se construye desde estas lógicas como la consecuencia natural del derecho a la identidad y del derecho al libre desarrollo de la personalidad, en el entendido de que los procesos de generización de un sujeto, si bien no son voluntarios, tampoco están determinados o anclados en una biología, y que es perfectamente posible ocupar posiciones sociales que no emanan de una lectura biologicista del sujeto, sino que remiten a cómo el sujeto se coloca dentro de un campo políticogenerizado.

\section{BibliografíA}

AlCÁNTARA, E., "Niñas y niños: el derecho a existir sin diagnóstico", Derecho a la identidad de género de niñas, niños y adolescentes, México, Tribunal Superior de Justicia-Consejo de la Judicatura de la Ciudad de México, 2016. 
BRAidotTI, R., Feminismo, diferencia sexual y subjetividad nómade, Madrid, Gedisa, 2015.

Butler, J., Bodies that Matter: On the Discursive Limits of Sex, Nueva York, Taylor \& Francis, 2011.

Campbell, F., Contours of Ableism: The Production of Disability and Abledness, Nueva York, Springer, 2009.

DERRIDA, J., Specters of Marx: The State of the Debt, the Work of Mourning and the New International, Nueva York, Routledge, 2012.

Foucault, M., The History of Sexuality: An Introduction, Nueva York, Vintage, 1990, vol. I.

Freeman, S. K. y Meyerowitz, J., How Sex Changed: A History of Transsexuality in the United States, Cambridge, Harvard University Press, 2004.

Grosz, E. A., Volatile Bodies: Toward a Corporeal Feminism, Indiana, Indiana University Press, 1994.

Guerrero MaManus, F., ¿Naces o te haces? La ciencia detrás de la homosexualidad, México, Paidós, 2013.

Guerrero MaManus, F. y MuÑoz Contreras, L., Epistemologías transfeministas e identidad de género en la infancia: del esencialismo al sujeto del saber, manuscrito sin publicar.

Hacking, I., "Historical Ontology", In the Scope of Logic, Methodology and Philosophy of Science, Ámsterdam, Springer Netherlands, 2002.

HaRAWAY, D., Simians, Cyborgs, and Women: The Reinvention of Nature, Nueva York, Routledge, 2013.

Harman, G., Prince of Networks: Bruno Latour and Metaphysics, Londres, re-Press, 2010.

Hayles, N. K., How We Became Posthuman: Virtual Bodies in Cybernetics, Literature, and Informatics, Chicago, University of Chicago Press, 2008.

JefFreys, S., "The Transgendering of Children: Gender Eugenics", Women's Studies International Forum, vol. 35, núm. 5, 2012. 
Latour, B., "On Actor-Network Theory: A Few Clarifications", Soziale welt, 1996.

Marause, H., Eros and Civilization: A Philosophical Inquiry into Freud, Nueva York, Beacon Press, 2015.

Ma Manus, F., "The Structure of Explanations and CounterExplanations of Homosexuality", The Open fournal of Philosophy, vol. 2, núm. 4, 2012.

Mol, A., The Body Multiple: Ontology in Medical Practice, Durham, Duke University Press, 2002.

Pons, A. y Garosi, E., "Trans", en Alcántara, Eva y MoRENO, Hortensia, Conceptos clave en los estudios de género, México, UNAM-PUEG, 2016.

PREGIADO, P., Manifiesto contra-sexual: prácticas subversivas de identidad sexual, Madrid, Pensamiento Opera Prima, 2002.

Preciado, P., Testo Yonki, Barcelona, Huertas, 2008.

Raymond, J. G., The Transsexual Empire, Nueva York, Beacon Press, 1980.

WEIS, G., Body Images: Embodiment as Intercorporeality, Nueva York, Routledge, 2013. 


\title{
PATOLOGIZACIÓN Y DESPATOLOGIZACIÓN DE LAS IDENTIDADES TRANS Y SU EXPRESIÓN EN LA GIUDAD DE MÉXICO. UN ESTUDIO MONOGRÁFICO
}

\section{María Fernanda LóPEz LóPEZ}

\begin{abstract}
SUMARIO: I. La construcción de la patología de las identidades trans. II. La movilización social por la despatologización de las identidades trans. III. De la patologización de la transexualidad al reconocimiento de la identidad de género: el caso de la Ciudad de México. IV. Conclusión. V. Bibliografia.
\end{abstract}

En esta investigación planteo la comprensión de las identidades, corporalidades y subjetividades trans, como experiencias heterogéneas no objetivables desde un modelo ontológico fijo, rígido y permanente. Sin embargo, para llegar a este planteamiento considero necesario, primero, la exploración monográfica del marco de entendimiento que hace inteligible, desde un discurso hegemónico, a las identidades trans: la patología. En un segundo momento propongo estudiar la contraparte de este proceso, mediante el análisis del estallido discursivo del activismo trans, en la Campaña Internacional por la Despatologización, que tiene expresiones locales en la Ciudad de México. Escenario donde, finalmente, ejemplifico: 1) la instauración de los discursos de la patologización de las identidades trans, insertos en las leyes y la atención médica de la Clínica Especializada Condesa, y 2) la emergencia de los discursos por la despatologización, materializados en la segunda reforma al Código Civil de 2015. 


\section{LA GONSTRUGGIÓN DE LA PATOLOGÍA DE LAS IDENTIDADES TRANS}

Antes de adentrarnos al análisis de la patologización de las identidades trans, es necesario abordar brevemente la importancia de la medicina como configuradora de la sexualidad en occidente. Una forma de realizar este análisis es mediante la genealogía que realiza Michel Foucault en su libro Historia de la sexualidad, vol. 1: La voluntad del saber. Donde plantea un estudio, a partir del siglo XVIII, de los diferentes discursos que construyen el dispositivo de la sexualidad; uno de ellos es la ciencia médica.

El auge de esta ciencia en el siglo XIX le permite posicionarse como un aparato destinado a producir la verdad sobre la sexualidad, mediante instituciones y autoridades que establecen un discurso científico en torno al sexo, el cuerpo y los sujetos. En estos discursos se argumenta la existencia natural del género binario y su correspondencia con el cuerpo sexuado y el deseo heterosexual. Nombra como "patologías" a todas las "experiencias que no encajan en este esquema, las cuales se vuelven objeto de procesos de normalización con la finalidad de restablecer el «orden natural» entre sexo y género". ${ }^{1}$

Una forma de enlazar los discursos de esta ciencia con el tema de esta investigación es mediante la elaboración de una "genealogía crítica de lo trans", como lo formulan las autoras Alba Pons y Eleonora Garosi, ${ }^{2}$ al intentar recuperar las conceptualizaciones que ha producido la medicina sobre lo trans. Se colocan como precedentes los trabajos de psiquiatría de Krafft-Ebing en 1877, y los trabajos de sexología de Magnus Hirschfeld en 1910, que hacen referencia a la teoría de los estadíos intermedios, distinguiendo a los sujetos travestidos de los sujetos homosexuales y

1 Garosi, Eleonora y Pons, Alba, "Trans", en Alcántara, Eva y Moreno, Hortensia, Conceptos clave en los estudios de género, México, UNAM-PUEG, 2016, p. 5 .

2 Ibidem, p. 1. 
los - en ese entonces - hermafroditas. Hirschfeld, además, crea en 1919 el Instituto para el Estudio de la Sexualidad en Berlín, donde se producen las primeras operaciones de cambio de sexo a lo largo de los años veinte.

En 1954, el médico y sexólogo alemán Harry Benjamin populariza el término "transexual" y "lo utiliza para distinguir a las personas que quieren una cirugía de reasignación genital, de las que no, consideradas travestidas". ${ }^{3}$ En este sentido, Benjamin establece los primeros criterios para el diagnóstico de la transexualidad en su obra El fenómeno transexual, de 1966, donde define a la persona transexual como "el sujeto que quiere vivir física, sexual y mentalmente como si perteneciera al sexo opuesto". ${ }^{4}$

La invención de El fenómeno transexual se concibe a la par de una serie de investigaciones que en la década de 1960 surgen en universidades estadounidenses, como la Universidad de California y la Universidad Johns Hopkins, donde por primera vez las perspectivas biológicas y psicológicas se combinan en el análisis de la identidad de género. Figuras como Robert Stoller, Richard Green y John Money "desarrollan desde el mundo de la medicina, las principales ideas que justifican la patologización de la homosexualidad, la transexualidad y la intersexualidad. Estas aportaciones juegan un papel muy importante en el debate sobre qué criterios tiene que cumplir una persona para ser diagnosticada como transexual". ${ }^{5}$

En 1979, Harry Benjamin publica el primer protocolo oficial para el tratamiento de la reasignación de género, llamado "Estándares de cuidado para los desórdenes de la identidad de género" (SOC, por sus siglas en inglés). Este protocolo plantea que "la transexualidad ha de ser diagnosticada por un psiquiatra, en tanto que se trata de un trastorno mental. Asimismo, profundiza

3 Missé, Miquel, Transexualidades: otras miradas posibles, 2a. ed., BarcelonaMadrid, EGALES, 2014, p. 32.

4 Garosi, Eleonora y Pons, Alba, op. cit., p. 4.

5 Missé, Miquel, op. cit., p. 34. 
en cómo deber ser el tratamiento psiquiátrico, endocrinológico y quirúrgico de las personas transexuales". ${ }^{6}$

Así, a partir de 1980, la transexualidad es clasificada por primera vez dentro del Manual diagnóstico y estadístico de trastornos mentales (DSM-III por sus siglas en inglés) de la Asociación Americana de Psiquiatría, bajo el nombre de "trastorno de transexualidad". Diez años después se integra como "trastorno de la identidad de género" a la Clasificación Internacional de Enfermedades (ICD, por sus siglas en inglés) de la Organización Mundial de la Salud.

En la versión del DSM-IV, de 1994, se señala que los "trastornos de la identidad de género" engloban la transexualidad y también el travestismo. En este sentido, como lo señala Miquel Missé, ${ }^{7}$ no sólo se considera que tienen un trastorno mental las personas que quieren modificar su cuerpo permanentemente, sino todas aquellas personas que viven en un género diferente al asignado al nacer. Éste es el motivo que explica por qué se habla de patologización de las identidades trans y no tanto de patologización de la transexualidad, dado que el abanico de trayectorias patologizadas es mucho más amplio.

Podemos concluir este apartado identificando cómo desde la perspectiva médica se ha construido un sujeto transexual. Al cual se le establece conforme a un diagnóstico: "trastorno de la identidad de género". Entre las características más importantes para la obtención de este diagnóstico se encuentran: "expresar el deseo de vivir en el otro género desde la infancia, el sentir rechazo hacia las características sexuales secundarias del propio cuerpo, hacia los genitales e incluso rechazo a tener relaciones sexuales". ${ }^{8}$ Estos criterios constituyen un ser transexual aceptable y legítimo, estableciendo una transexualidad normativa, que excluye la inteligibilidad de otras formas de ser trans.

\footnotetext{
6 Ibidem, p. 35.

7 Ibidem, p. 36.

$8 \quad$ Ibidem, p. 51.
} 


\section{LA MOVILIZAGIÓN SOGIAL POR LA DESPATOLOGIZAGIÓN DE LAS IDENTIDADES TRANS}

En la búsqueda por hacer sonar las voces de quienes encarnaban la patología definida como transexual desde la medicina, así como aquellas voces de personas que no se identificaban con esta categoría, pero aun así recuperan el vocablo "trans" para describir su experiencia de no identificación con el género y/o el sexo asignado corporalmente, y aquellas otras voces de quienes buscan salir del binarismo de género para dar paso a una identidad fluida, se construye la Red Internacional por la Despatologización de las Identidades Trans, en un intento por deshacer el marco conceptual que coloca a sus cuerpos y expresiones de género como patologías.

Antes de adentrarnos por completo a la gestación de este movimiento social, desde lo que podemos llamar la comunidad trans, debemos hacer referencia a los colectivos y organizaciones alrededor del mundo, integrados por personas trans. Es necesario señalar que no existe un consenso alrededor de la reivindicación de la despatologización. Ya que "por un lado existen miembros de la comunidad que apuntan a un uso estratégico de la categoría para la obtención de recursos, tanto públicos como privados (seguros médicos), que les permitan financiar sus tratamientos médicos y las operaciones de reasignación sexual". 9 Por otro lado se encuentran aquellos miembros que suscriben el suprimir la existencia del trastorno mental, por sus implicaciones simbólicas, productivas y violentas, y la búsqueda por exigir atención sanitaria desde un marco fuera de la patologización. Bajo esta última estrategia se enmarca la organización del movimiento social por la despatologización de las identidades trans.

Tomando en cuenta el poder-saber que la Asociación Americana de Psiquiatría ejerce en la atención clínica psiquiátrica y

9 Coll-Planas, Gerard, "Introducción", en Coll-Planas, Gerard y Missé, Miquel (eds.), El género desordenado: críticas en torno a la patologización de la transexualidad, 2a. ed., Madrid-Barcelona, EGALES, 2010, p. 20. 
psicológica alrededor del mundo, con la publicación de sus manuales diagnósticos y estadísticos de trastornos mentales, a finales de la década del 2000, en España, se organiza la Campaña Internacional por la Despatologización de las Identidades Trans, llamada: Stop Trans Pathologization 2012. La cual tiene como propósito utilizar como coyuntura la quinta edición en 2012 del manual DSM para proponer la descatalogación de la categoría "disforia de género". Además de la eliminación de la categoría "trastornos de la identidad de género" del CIE-11.

La propuesta de esta acción y su convocatoria a nivel mundial tiene sus orígenes en el activismo trans a inicios de 2006 en Barcelona. Donde encontramos al "grupo de resistencia queer y trans" Guerrilla Travolka, que comienza a "realizar denuncias públicas sobre el tratamiento psiquiátrico del trastorno de la identidad de género, apostándole así a la despatologización de la transexualidad mediante la visibilización de cuerpos trans no normativos, y experiencias trans que no se definían a través de diagnósticos". 10

En 2007, este grupo de activistas realiza la primera marcha de lucha transexual, transgénero e intersex, en Barcelona, apoyado por el movimiento antipsiquiatría y colectivos feministas y transfeministas autónomos. Logra gestar la Red Estatal por la Despatologización Trans, a la cual se unirán posteriormente colectivos de diferentes ciudades españolas.

El 21 de octubre de 2009, la Red gesta - mediante su sitio de Internet - ${ }^{11}$ la difusión internacional de la convocatoria del "Día Internacional de Acción por la Despatologización Trans", dirigida a activistas trans y grupos aliados en todo el mundo. Logrando, ese año, un alcance en 41 ciudades de América Latina, Asia, Europa y Norteamérica, en donde se llevaron a cabo diversas actividades en torno a la despatologización trans.

10 Garosi, Eleonora y Pons, Alba, op. cit., p. 7.

11 Stop Trans Pathologization 2012, disponible en: http://stp2012.info/old/ es [consultado en noviembre de 2017]. 
Los objetivos de la ahora Red Internacional por la Despatologización Trans, al establecer la campaña Stop Trans Pathologization 2012 (STP-2012) y el Día Internacional de Acción por la Despatologización Trans, son los siguientes:

\section{Objetivos: ${ }^{12}$}

1. Retirada de la categoría de "disforia de género" / "trastornos de la identidad de género" de los manuales internacionales de diagnóstico (sus próximas versiones DSM-5 y CIE-11).

2. Abolición de los tratamientos de normalización binaria a personas intersex.

3. El libre acceso a los tratamientos hormonales y a las cirugías (sin tutela psiquiátrica).

4. La cobertura pública de la atención sanitaria transespecífica (acompañamiento terapéutico voluntario, seguimiento ginecológico-urológico, tratamientos hormonales, cirugías).

5. La lucha contra la transfobia: el trabajo para la formación educativa y la inserción social y laboral de las personas trans, así como la visibilización y denuncia de todo tipo de transfobia institucional o social.

La incorporación de la comunidad intersex a los objetivos y el manifiesto ${ }^{13}$ de la organización se plantea como inclusión de otra identidad patologizada, producto del discurso hegemónico médico y psiquiátrico, que constriñe a los sujetos y sus corporalidades a un binarismo de género único. Por otro lado, el último objetivo busca hacer explícita la lucha por la transfobia, la cual se ha convertido en un comportamiento sistemático, establecido por instituciones, medios de comunicación y sociedad civil en

12 Véase http://stp2012.info/old/es/objetivos.

13 Para consultar el manifiesto véase $h t t p: / / s t p 2012$ info/old/es/manifiesto. 
general, que es posible medir mediante experiencias de discriminación y violencia hacia los integrantes de la comunidad trans.

De esta forma, lo que inició como un movimiento social de protesta pública focalizada ha crecido hasta transformarse en una red internacional que continúa año con año convocando acciones bajo estos objetivos. La recepción de su convocatoria en todo el mundo ha demostrado que existe un apoyo creciente a la demanda por la despatologización. En el caso de México, éste ha participado en la campaña desde 2010, registrando hasta 2017 la participación de 27 organizaciones aliadas. ${ }^{14}$ Ellas representan a activistas de diversos estados, como Baja California, Guanajuato, Jalisco, Chiapas, Querétaro, Monterrey, San Luis Potosí, Ciudad de México y Puebla.

Las actividades que se han realizado en México en el marco de la campaña incluyen los pronunciamientos, performances, brigadas, talleres, conversatorios, ciclos de cine, conferencias, coloquios y mesas de diálogo en diferentes lugares como museos, universidades, espacios públicos y recintos como la Comisión de Derechos Humanos del entonces Distrito Federal (CDHDF). En 2012, en el estado de Puebla, asociaciones y colectivos trans realizaron una movilización de protesta por el asesinato de Agnes Torres, activista trans. Y en 2013, en el marco de la campaña, presentaron la llamada "Reforma Agnes Torres" por el reconocimiento jurídico de las personas trans en el estado.

De esta manera "se pone de manifiesto el carácter múltiple y culturalmente diverso de la movilización que, en cada contexto político y a partir de las demandas principales, los grupos de activistas han creado sus propios discursos y reivindicaciones que reflejan sus realidades localmente específicas". ${ }^{15}$ Asimismo,

14 Para conocer el nombre de las organizaciones adheridas al movimiento puede verse: http://stp2012.info/old/es/adhesiones.

15 Suess, Aimar, "Análisis del panorama discursivo alrededor de la despatologización trans: procesos de transformación de los marcos interpretativos en diferentes campos sociales", en Coll-Planas, Gerard y Missé, Miquel, op. cit., p. 43. 
en nuestro país, la incursión de la campaña ha permitido dar continuidad año con año a eventos como el coloquio internacional "Travestis, transexuales, transgéneros e intersexuales: lo trans-lúdico detonante", organizado por la ENAH y la CDHDF, y el Encuentro Internacional Trans organizado por Prodiana, A. C. Los cuales se convierten en espacios potentes de encuentro y discusión para la propia comunidad trans.

La publicación del Manual diagnóstico DSM-V se realizó en 2013, un año después de lo previsto por la Red. En su nueva edición el Manual modificó nominalmente la definición psiquiátrica del "trastorno de identidad de género" por el desorden de "disforia de género", lo cual no trae un cambio sustancial en la concepción del fenómeno trans. Aunado a estos cambios, "se incluyen nuevos criterios diagnósticos, diferenciados en función de la edad — niños, niñas, adolescentes y adultos/as-, en los que también se pueden llegar a incluir a personas diagnosticadas con DSD (Disorder of Sexual Development), nombradas en ocasiones como intersex". ${ }^{16}$

A diferencia de la falta de cambios sustanciales en el DSM, la Asociación Mundial Profesional de la Salud para las Personas Transgénero (WPATH, por sus siglas en inglés) realizó modificaciones en 2012 a la séptima publicación de sus Normas de atención para la salud de las personas trans y con variabilidad de género (SOC-7, por sus siglas en inglés). En esta publicación "se modificó radicalmente el lenguaje y se incluyeron nuevas categorías que antes no estaban contempladas, como, por ejemplo, la variabilidad de género y la categoría trans, en lugar de transexual o transgénero" ${ }^{17}$

La introducción de una nueva forma conceptual de concebir a las personas trans dentro del SOC-7 sigue partiendo de una relación intrínseca con el diagnóstico de "disforia" que el propio Manual define como: "la condición de incomodidad o malestar

16 Garosi, Eleonora y Pons, Alba, op. cit., p. 4.

17 Pons, Alba, De las transformaciones sociales a las micropolíticas corporales: un archivo etnográfico de la normalización de lo trans* y los procesos de corposubjetivación en la Ciudad de México, tesis de doctorado, México, UAM-I, diciembre de 2016, p. 67. 
causado por la discrepancia entre la identidad de género y el sexo asignado a las personas al nacer". Ante este panorama, ¿qué opinión es posible emitir respecto a la evaluación y/o balance del trabajo realizado por la Red Internacional por la Despatologización Trans?

Sin duda, partiendo de los objetivos que plantea sobre la despatologización y la abolición de los tratamientos quirúrgicos a las personas trans, todavía existe un largo camino por recorrer. Ya que realmente estos postulados implican librar una batalla política, donde se anulen los discursos de instituciones médicas de poder-saber, que sostienen la construcción social de la sexualidad en occidente.

No obstante, es preciso pensar como avances hacia la despatologización, el reconocimiento de la variabilidad del género en el SOC-7 y la apertura de protocolos médicos que rompan con el esquema tripartita, unidireccional, de: 1) valoración psicológica; 2) tratamiento endocrinológico, y 3) intervención quirúrgica, que no se adecua a las necesidades de todas las personas trans. Asimismo, la implementación de tratamientos que partan desde un "régimen de autonomía" donde las personas trans se conviertan en su propia autoridad y "el único propósito de los médicos sea el buscar subsanar la salud psíquica del usuario, asegurándose que ha recibido suficiente información sobre el proceso de transición, permitiéndole ejercer el pleno derecho de decisión sobre su vida y responsabilidad sobre sus posibles errores, como corresponde a una persona mayor de edad". ${ }^{18}$

Mientras que en el plano intersex, propuestas como la "Guía de recomendaciones para la atención de intersexualidad y variación en la diferenciación sexual", realizada en 2017 en México, plantean una propuesta para el acceso sin discriminación a la prestación de servicios de atención médica. Además, en el plano internacional, gracias a la organización activista Intersex se han

18 Pérez Fernández-Fígares, Kim, "Historia de la patologización y despatologización de las variantes de género", en Coll-Planas, Gerard y Missél, Miquel, op. cit., p. 105. 
logrado disposiciones legislativas como en Malta, donde se prohíben las cirugías y el tratamiento de los caracteres sexuales de los menores sin consentimiento. ${ }^{19}$

\section{DE LA PATOLOGIZACiÓN DE LA TRANSEXUALIDAD AL RECONOCIMIENTO DE LA IDENTIDAD DE GÉNERO:} EL GASO DE LA GiUdAD DE MÉXICO

Este último apartado constituye una recopilación del proceso de la construcción de la patologización de las identidades trans en la Ciudad de México, recuperado en dos discursos: la reforma de 2008 al Código Civil y los servicios de salud que proporciona a la comunidad la Clínica Condesa. En un segundo momento se realiza un análisis de la organización social Coalición T47, que se gestó para impulsar la desjudicialización y despatologización de la identidad de género en 2015.

En México, el inicio del nuevo milenio se encuentra enmarcado por lo que se conoce como "periodo de transición democrática", en donde los cambios en el sistema político no sólo se viven con la aparición de nuevos actores, sino también con el nacimiento de nuevas instituciones como el Consejo Nacional para Prevenir y Eliminar la Discriminación (Conapred), y la "instauración de un valor central: el respeto a las diferencias. En este escenario cultural y político, la noción de «diversidad sexual» se nutre de un enorme potencial". ${ }^{20}$

Bajo este panorama, organizaciones internacionales de derechos humanos realizan presión para "modernizar" los marcos jurídicos nacionales, "en pos de la igualdad y los ideales antidiscriminatorios de organizaciones activistas, y de cara a la inclusión

19 Naciones Unidas, Ficha de datos intersex, disponible en: https://unfe.org/ system/unfe-72-Intersex_Factsheet_SPANISH.pdf, p.2 [consultada en noviembre de $2017]$.

20 Núñez Noriega, Guillermo, ¿Qué es la diversidad sexual?, 2a. ed., México, UNAM-PUEG, 2016, p. 43. 
de los «otros sexuales» dentro de los parámetros de ciudadanía”. ${ }^{21}$ De esta manera, en México, comienzan a presentarse iniciativas federales y locales para conseguir el reconocimiento legal de la identidad de género.

Así, en 2007, por medio del diputado federal del PRD David Sánchez Camacho, se presenta una iniciativa de Ley Federal para la No Discriminación de los Derechos Humanos y Civiles de las Personas Transgénero y Transexuales. La iniciativa no obtuvo el apoyo necesario para su aprobación, por lo que se comenzó a pensar en realizar una segunda propuesta de ley para el entonces Distrito Federal, tomando en cuenta su composición partidista y las leyes precedentes que se habían logrado aprobar en su jurisdicción, como la Ley de Sociedades de Convivencia en 2006 y la reforma que permite la interrupción legal del embarazo durante las doce primeras semanas de gestación en 2007.

De esta manera, para la concepción de una nueva propuesta de ley fue necesaria la conformación de una Red de Trabajo Trans integrada por abogados, asambleístas, investigadores, sexólogos y organizaciones de la diversidad sexual, la cual no sólo reclamaba el reconocimiento de la personalidad jurídica de las personas transexuales, transgénero y travestis, sino la reforma a la Ley General de Salud para incluir la atención de salud transicional para aquellas personas que la necesitaran. ${ }^{22}$

Esta propuesta fue rechazada por el Poder Ejecutivo, al argumentar falta de presupuesto para su ejercicio, provocando así una ruptura entre la Red de Trabajo Trans y los y las legisladoras, quienes presentaron en agosto de 2008 una iniciativa para reformar y adicionar el Código Civil y el Código de Procedimientos Civiles para la emisión de actas de nacimiento por la vía de un "juicio especial de levantamiento de actas de nacimiento por reasignación para la concordancia sexo-genérica”.

21 Sabsay, Leticia, "Políticas queer, ciudadanías sexuales y descolonización”, Resentir lo queer en América Latina, 2014, p. 49.

22 Pons, Alba, op. cit., p. 44. 
La publicación de esta reforma en la Gaceta Oficial del Distrito Federal en octubre de 2008 se dirige a aquellas personas que requieran el reconocimiento de su identidad de género, entendida como "la convicción personal de pertenecer al género masculino o femenino". ${ }^{23}$ En este sentido, la definición de identidad de género se constriñe a un binarismo, en el que además, en este paradigma, la identidad de hombre y mujer se plantea como eterna e inmutable.

La reforma de 2008 también condiciona el levantamiento de acta de nacimiento al proceso de "reasignación de concordancia sexo-genérica", definido como:

El proceso de intervención profesional, mediante el cual la persona obtiene concordancia entre los aspectos corporales y su identidad de género, que puede incluir, parcial o totalmente: entrenamiento de expresión de rol de género, administración de hormonas, psicoterapia de apoyo o las intervenciones quirúrgicas que haya requerido en su proceso. ${ }^{24}$

En la reforma de ley también se estipula que estos parámetros serán comprobables mediante una resolución judicial que, en caso de ser válida, permitirá la resolución jurídica de una identidad jurídica de hombre o mujer. En el artículo 498 bis se señalan como requisitos para la solicitud de una nueva acta de nacimiento: la nacionalidad mexicana, la mayoría de edad y la anexión de un dictamen que señale que la persona se encuentra sujeta al proceso de reasignación para la concordancia sexo-genérica con un mínimo de cinco meses; éste tiene que ser expedido por dos profesionistas o peritos que cuenten con experiencia clínica en materia de procesos de reasignación para la concordancia sexogenérica, y uno de ellos deberá ser el profesionista a cargo del tratamiento solicitante. ${ }^{25}$

23 Código Civil del Distrito Federal, artículo 135 bis, 2008.

24 Idem.

25 Código Civil del Distrito Federal, artículo 498 bis, 2008. 
Ante este panorama, el reconocimiento jurídico de las personas trans se encuentra regulado por una perspectiva médica, que reconoce las identidades sólo al inscribirse en una lógica de "concordancia" entre los aspectos corporales y la identidad de género binaria. La ley también recupera al paradigma médico al inscribir los procesos de "reasignación" en un marco psicológico, endocrinológico y quirúrgico. Aunado a esto, en esta reforma se estipula que el proceso de "reasignación" sólo tendrá validez tras ser reconocido por una figura de autoridad "profesional". En este rubro, las vacantes de "peritos especializados" eran cubiertas por sexólogos privados.

Como vimos anteriormente, las modificaciones al Código Civil de 2008 dejaron de lado la defensa al acceso a la salud transicional para las personas trans que así lo necesitaran. Sin embargo, en 2009 se publicó en la Gaceta Oficial de la Asamblea Legislativa la Ley General de Salud de la Ciudad de México, que incluye en sus estatutos la implementación del Programa Transgénero en la Clínica Especializada Condesa, el cual busca establecer el acceso gratuito a terapias hormonales, acompañamiento psicoterapéutico y detección oportuna del VIH y otras infecciones de transmisión sexual.

El hecho de la implementación de los programas de atención a la salud de la población trans en la Clínica Especializada Condesa "causó revuelo en algunos colectivos de activistas trans, que consideraron como estigmatizante el ser atendidos en una clínica especializada para el tratamiento del VIH, ya que no todas ni todos están involucrados en prácticas de riesgo o padecen esta enfermedad", ${ }^{26}$ además de la asociación simbólica que remite el pensar la relación entre personas trans, el VIH y el trabajo sexual.

En este análisis colocamos como patologizador el proceso de atención médica de la Clínica Condesa, ya que condiciona el tratamiento hormonal a las personas trans que se reconozcan bajo

26 Pons, Alba, op. cit., p. 59. 
el parámetro de sujetos transexuales y/o transgéneros construido por el Manual diagnóstico y estadístico de desórdenes mentales (DSM) y en la Clasificación Internacional de Enfermedades (CIE), aun y cuando el uso de los manuales diagnósticos que consideran a las identidades trans como trastornos mentales inferiorizan al sujeto y niegan la autodeterminación de su cuerpo, incurriendo así en la vulneración de sus derechos humanos. ${ }^{27}$

La atención en la Clínica Especializada Condesa se plantea en un esquema de atención médica unidireccional que inicia con una valoración física y psicológica de los pacientes. Esta última "tiene los objetivos de descartar algún trastorno mental grave y diagnosticar disforia de género. Para que si la persona es diagnosticada únicamente con disforia de género, adquiera el permiso para pasar a endocrinología". ${ }^{28}$ Así, la Clínica impide claramente el ejercicio pleno del derecho a la salud de las personas trans, aunado a que no ofrece los servicios de reasignación sexual ni cirugías de otro tipo. A pesar de este panorama, la Clínica Condesa plantea estar enmarcada en un esquema de garantía de los derechos humanos.

Finalmente, en esta investigación abordaremos el análisis del panorama jurídico actual con el que vive la comunidad trans en la Ciudad de México, quien en 2015 logra promover una segunda reforma al Código Civil, que incluye la desjudicialización y despatologización del reconocimiento de las identidades de género, mediante la conformación de la Coalición T47, en 2014.

A inicios de la segunda década del año 2000, instituciones en el Distrito Federal, como la Comisión de Derechos Humanos y el Consejo para Prevenir y Eliminar la Discriminación, comenzaron a incorporar en sus agendas a la población transexual, transgénero y travesti, como parte de la "diversidad sexual", promoviendo espacios de visibilidad y denuncia de la vulneración de sus derechos humanos.

27 Ibidem, p. 62.

28 Ibidem, p. 70. 
Este contexto, aunado a la composición legislativa en la Asamblea Legislativa del Distrito Federal, permitió colocar un terreno fértil para la elaboración de una reforma de desjudicialización y despatologización del modelo de reconocimiento de las identidades de género. En este proceso se conforma la Coalición T47, integrada por distintas organizaciones trans tanto de la Ciudad de México como de otros estados. Como señala Alba Pons en su tesis de doctorado, "el hecho de que desde 2009, cada mes de octubre, varias organizaciones habían participado dentro de la Campaña Internacional por la Despatologización Trans, había permitido socializar el término, su significado y su importancia entre la comunidad". ${ }^{29}$

El paradigma que permitió impulsar esta segunda reforma fueron los derechos humanos, con los cuales se dejó de hablar de la "concordancia sexo-genérica" y se planteó como concepto central la "identidad de género", que conforme a los Principios de Yogyakarta era reconocida como un derecho al propio cuerpo. Así, en el texto promulgado en 2015 se establece que pueden pedir el levantamiento de una nueva acta de nacimiento, las personas que requieran el reconocimiento de su identidad de género. Entendiendo esta última como: "La convicción personal e interna, tal como cada persona se percibe a sí misma, la cual puede corresponder o no, al sexo asignado en el acta primigenia. En ningún caso será requisito acreditar intervención quirúrgica alguna, terapias, u otro diagnóstico y/o procedimiento para el reconocimiento de la identidad de género". ${ }^{30}$

En este sentido, se realizan cambios sustanciales en comparación con la reforma de 2008, la cual reducía el entendimiento de "identidad de género" a la convicción personal de pertenecer a un género masculino o femenino. En la actualidad, la ley no fija la identidad a la pertenencia a un género binario, abriendo paso a la posibilidad de reconocimiento y autodeterminación fluida o

\footnotetext{
29 Ibidem, p. 91.

30 Código Civil de la Giudad de México, artículo 135 bis, 2015.
} 
no binaria. También se coloca el acento en que en ningún caso es requisito el demostrar o validar intervención quirúrgica o procedimiento médico alguno, además de que la figura de los peritos "especializados" desaparece. Logrando así escapar de la patologización y medicalización de la ley.

La segunda reforma al Código Civil fue publicada en la $\mathrm{Ga}$ ceta Oficial del Distrito Federal el 5 de febrero de 2015. Ésta coloca como autoridad responsable del levantamiento de una nueva acta de nacimiento para el reconocimiento de la identidad de género, a los y las jueces del Registro Civil del Juzgado Central de la Ciudad de México. En la actualidad, a dos años de la promulgación de la ley, existe el registro de la expedición de más de 1,900 actas de nacimiento.

\section{CONCLUSIÓN}

Esta investigación nos permite obtener un panorama amplio del proceso de patologización de las identidades trans, sostenida por discursos como los instaurados en la ciencia médica y en las leyes, como el caso de la reforma al Código Civil de 2008 en la Ciudad de México. La patología se convierte así en el marco conceptual que hace inteligible las identidades, subjetividades y corporalidades trans como enfermedades que necesitan ser curadas. Colocar desde este plano a las identidades trans es resultado de la transfobia cultural que impide el reconocimiento de una expresión de género diferente a la establecida por la matriz heterosexual que establece Judith Butler. Donde el género femenino o masculino corresponde a un sexo biológico hembra o macho y a un deseo herterosexual hacia los hombres o mujeres, según sea el caso.

Como se plantea en este trabajo, los discursos gestados desde el activismo trans han colocado en distintos planos, tanto local como internacional, una apuesta de configuración alternativa que niega la enunciación de lo trans e intersex desde la patología, y además plantea la existencia de una realidad heterogénea, 
compuesta de una pluralidad de identidades trans en constante reconfiguración. Así, los discursos del activismo trans impulsan el ejercicio autónomo del derecho a la autodeterminación de la identidad de género y las demandas en torno al ejercicio de los derechos humanos trans, que incluyen, entre otros, el derecho a una vida libre de violencia y el derecho a recibir atención médica en los procesos de transición, para quienes consideren necesaria la medicalización o modificación quirúrgica de sus cuerpos. Si bien la medicina ha construido las patologías, también ha permitido el desarrollo de tecnologías que permiten contribuir al bienestar de las personas trans. Finalmente, el hacer un intento por ejemplificar los procesos de patologización y despatologización en la Ciudad de México tiene como propósito el contextualizar el cómo son leídos y configurados ciertos cuerpos desde nuestra realidad cercana.

\section{BIBLIOGRAFÍA}

Coll-Planas, Gerard y Missé, Miquel (eds.), El género desordenado: críticas en torno a la patologización de la transexualidad, 2a. ed., Madrid-Barcelona, EGALES, 2010.

Coll-Planas, Gerard, "Introducción", en Coll-Planas, Gerard y Missé, Miquel (eds.), El género desordenado: críticas en torno a la patologización de la transexualidad, 2a. ed., Madrid-Barcelona, EGALES, 2010.

Garosi, Eleonora y POns, Alba, "Trans", en Alcántara, Eva y Moreno, Hortensia, Conceptos clave en los estudios de género, México, UNAM-PUEG, 2016.

Missé, Miquel, Transexualidades: otras miradas posibles, 2a. ed., Madrid-Barcelona, EGALES, 2014.

NAGIONES UNIDAS, Ficha de datos intersex, consultada en noviembre de 2017, disponible en: https://unfe.org/system/unfe-72-Intersex_ Factsheet_SPANISH.pdf. 
NúÑEZ NoriegA, Guillermo, ¿Qué es la diversidad sexual?, 2a. ed., México, UNAM-PUEG, 2016.

PÉREZ FERnÁNDEZ-Fígares, Kim, "Historia de la patologización y despatologización de las variantes de género", en COLLPlanas, Gerard y MisséL, Miquel (eds.), El género desordenado: críticas en torno a la patologización de la transexualidad, 2a. ed., Madrid-Barcelona, EGALES, 2010.

PONS, Alba, De las transformaciones sociales a las micropolíticas corporales: un archivo etnográfico de la normalización de lo trans* y los procesos de corposubjetivación en la Ciudad de México, tesis de doctorado, México, Universidad Autónoma Metropolitana-I, diciembre de 2016.

SABSAY, Leticia, "Políticas queer, ciudadanías sexuales y descolonización", en FALCONí et al. (eds.), Resentir lo queer en América Latina, 2014.

SuESS, Aimar, "Análisis del panorama discursivo alrededor de la despatologización trans: procesos de transformación de los marcos interpretativos en diferentes campos sociales", en COLLPlanas, Gerard y MisséL, Miquel (eds.), El género desordenado: críticas en torno a la patologización de la transexualidad, 2a. ed., Madrid-Barcelona, EGALES, 2010. 


\title{
QUEBRANTO: PROFANAR UN LUGAR SAGRADO Y ENTRAR EN ÉL SIN PERMISO
}

\author{
Andrea Angulo Menasse
}

\begin{abstract}
SUMARIO: I. Podré reír, y cantar y bailar disfrutando la vida. II. Si no fuera feliz, no estuviera asi ni me hubiera puesto chichis. III. Puedo actuar de hombre o mujer, no tengo problemas de estacionamiento. IV. La vida es rasposa (forge Fons). V. Bibliografia.
\end{abstract}

\author{
I. PODRÉ REÍR, Y CANTAR \\ Y BAILAR DISFRUTANDO LA VIDA
}

La identidad no es un destino sino una decisión.

Jeffrey WEEKS

La definición de la palabra "quebranto" en el Diccionario de la Real Academia de la Lengua Española hace referencia a violar una ley o no cumplir una obligación. ${ }^{1}$ Es "profanar un lugar sagrado" y "un punto de quiebre" donde, en el caso de la protagonista de la película Quebranto, la identidad de hombre que le fue impuesta se interrumpe para que otra, coherente con su vivencia subjetiva, vea la luz.

Se trata de la historia de Fernando García, antes, durante y después de que decidiera profanar "el lugar sagrado" de la iden-

1 Diccionario de la Real Academia de la Lengua Española, 2017. 
tidad "mujer", sin permiso y con mucha convicción, convirtiéndose en "Coral Bonelli".

El documental de Fiesco (2013) representa la conmovedora historia de dos personas: Fernando García y la actriz Lilia Ortega, su madre, involucradas en el medio cinematográfico de la época de oro del cine mexicano y de toda la riqueza que ese periodo de la historia tuvo para México. Fernando García "El Pinolito" figuró en el cine de los años setenta y compartió créditos con las actrices Katy Jurado y Sara García, pero también sufrió las consecuencias del desmantelamiento de esa industria pública en los años ochenta en nombre del libre mercado.

El documental de Fiesco es también la historia de vida de dos generaciones, y un poco también la historia de la Ciudad de México en su condición de ciudad "trans": transformada, transitada, transgredida. La ciudad de las paradojas, de la riqueza insultante y la ofensiva pobreza.

La que se cayó en 1985 y volvió a nacer gracias al despertar de la sociedad civil y a pesar de sus gobiernos local y federal. Fernando y su madre fueron víctimas de esta catástrofe.

El país se encontraba en la peor crisis del México moderno por la caída en $1000 \%$ del peso frente al dólar, el desplome de la producción, la disminución del poder adquisitivo, el altísimo grado de desempleo y desocupación, que había alcanzado niveles de riesgo social y político.

Los nuevos gobernantes, orgullosos egresados de Economía de la Escuela de Chicago, ${ }^{2}$ concibieron e impusieron programas de "reajuste económico" que desarrollaron al renegociar la deuda con el Fondo Monetario Internacional (FMI) a condición de que aplicaran "un plan de austeridad" que contemplara la reducción del gasto público, así como la venta de empresas paraestatales y estatales. El pago de intereses de la deuda externa provocó la

2 La Escuela de Economía de Chicago asume la perspectiva económica del libre mercado, que se originó en los departamentos de Economía y en la escuela de negocios de Booth, a mediados del siglo XX, liderada por Milton Friedman y George Stigler. 
desnacionalización de la economía, así que, casi inmediatamente después de tomar el poder, De la Madrid dio marcha atrás a la nacionalización bancaria efectuada por López Portillo en 1982. En este contexto ocurrió el terremoto de la Ciudad de México, en el que el primer hijo de Lilia, de tan sólo 17 años, falleció:

Estábamos en la casa. Estábamos dormidos y empezó el terremoto. Rápido nos salimos, pero apenas cruzamos la puerta ¡tras!, se cayó la casa. Él (mi hermano) quedó adentro, nosotros estábamos afuera. Murió de una fractura de cráneo, pero como seis de columna. Cuando lo sacaron ya parecía muñeco de trapo, se hacía de un lado para el otro (Coral).

En Quebranto, Coral y su madre le llevan serenata a Pedro a su tumba, y a propósito de su santo le cantan su canción favorita, "Maldito abismo", en una clara alusión y también homenaje a la música de José Alfredo Jiménez y al marido de Lilia Ortega, el mariachi con el que se casó a los 13 años.

Los sismos destruyeron 3 mil 600 viviendas. Hubo alrededor de 30 mil damnificados, 17 mil de ellos pernoctaban en albergues a cielo abierto y el resto fueron alojados por familiares, pero el regente de la ciudad Ramón Aguirre Velázquez, lejos de dimensionar el problema, declaró que el país estaba preparado para salir de la emergencia y rechazó la ayuda internacional. Cuando, al fin, la sociedad civil demostró que el gobierno no podía rescatar a sus hermanos, se decretó estado de emergencia y se recibió apoyo del extranjero.

En esta trama, producto de la violencia estructural y la corrupción, se contextualizan las escenas y testimonios de Quebranto, en las que se muestra dónde vivía la familia de Fernando cuando fue sorprendido imitando a Raphael: un cuarto que hacía las veces de baño, cocina, comedor, recámara, todo, como tantas otras casas-cuarto en México. 


\section{Si NO FUERA FELIZ, NO ESTUVIERA ASÍ NI ME HUBIERA PUESTO CHICHIS}

Quebranto es también un homenaje a Raphael, el canta autor español, porque gracias a su existencia y estilo Coral se descubrió artista al mismo tiempo que trans, quebrantadora del orden de género hegemónico. Representa un homenaje a la música de la década de los años setenta, a Lucha Villa, a la Plaza de Garibaldi. Un documento que encarna parte de la memoria histórica de la Ciudad de México, las décadas de los años setenta, ochenta y noventa, y la historia de un niño que tiene grabada su infancia en más de treinta películas, así como su carrera a la luz de su transición identitaria.

Ser trans implica un movimiento hacia una identidad más coherente consigo, más sentida, e implica enormes ganancias que ser lo que se quiere ser conlleva. Las palabras que las personas trans asocian con el proceso de asumirse como lo que son frecuentemente representan posibilidades: libertad, liberación, autenticidad, la felicidad de ser coherente. ${ }^{3}$

Pero también desaliento, aflicción y pena, porque implica el duelo de quien se deja ir, para encarnar a otra. Quebranto presenta a Coral mostrándose: en su casa, su vida íntima, dentro del dormitorio con su madre, en cuyo alrededor se atropellan todo tipo de cosas: medicinas, pomadas, una radio, postales de la virgen, muñecos de todo tipo, bailarinas de vidrio con tutú, fotos de bailarines, santos, calendarios, grabadoras de casetes, películas VHS, perfumes, gel, cremas, Pepto Bismol, libros en estantes, payasitos, muñecos de peluche, peines y cepillos. Vemos el cuarto de su infancia, su azotea, las calles aledañas, su trabajo, o mientras lava la ropa los fines de semana. La particular relación con su madre, sus logros, sus tristezas y también el balance que hace a posteriori de sus decisiones: "He hecho cosas que me han dado satisfacciones, así que por ese lado soy feliz. Y ahora como soy,

3 Documental "Salir", disponible en: https://wwrw:youtube.com/watch?v $=0$ $\mathrm{CuQl} 8 \times \mathrm{Fx} 90$. 
realmente ahora, pues mucho más feliz, y me siento a gusto, si no fuera feliz, no estuviera así ni me hubiera puesto chichis... pero soy feliz. La verdad" (Coral).

En este tejido que es Quebranto, vamos conociendo la historia de este Raphaelito, a caballo con la historia de cómo se va identificando con figuras arquetípicas y descubriéndose, transformándose y reinventándose en ese camino único de autoconstruirse a sí misma. Como dice el director Jorge Fons, al que Coral visita después de transicionar: "A mí me da gusto que los hombres hagan triples mortales y que tomen grandes decisiones, demuestran que los grandes cambios pueden venir para un hombre o para una sociedad, cambios radicales, cambios fundamentales. Cambios verdaderos".

Parece que no hay mayor expresión de que lo simbólico subsume a lo biológico que el proceso biopsicosocial por el cual atraviesan las personas trans. Pinolito recibió este apodo, que funcionó de nombre artístico, cuando lo vieron cantar por primera vez, cuando lo nombraron pensando en un pino pequeño que echaría raíces fuertes y sería alto. Como su ideal, Rafael, Fernando empezó su carrera antes de los seis años haciendo que su infancia estuviera pautada por las películas que hizo, los actores con los que compartió la escena y los directores que le daban instrucciones que, por cierto, y a pesar de que él las siguiera con obediencia ciega, se caracterizaban por ser bastante terribles: como la de dejarse golpear por otro niño con una piedra hasta sangrar en $F$, esperanza y caridad, o por la misma Katy Jurado, que presumía de haberle golpeado con todas sus fuerzas para darle realidad a la escena.

\section{PUEDO ACTUAR DE HOMBRE O MUJER, NO TENGO PROBLEMAS DE ESTACIONAMIENTO}

Quebranto también significa desaliento, decaimiento físico o moral, y es que desde septiembre de 2016 México superó a Brasil en 
manifestaciones abiertas de trans y homofobia e incidencia de crímenes de odio. Así, pasamos del segundo al primer lugar en asesinatos por homo y transfobia en el mundo. En 2015, la Comisión Ciudadana contra los Crímenes de Odio por Homofobia señaló datos que evidentemente están vinculados con el desaliento: de 1995 a 2014 se registraron mil 218 homicidios por homo/transfobia en el país, y se estima que por cada caso reportado existen tres o cuatro más que no se denuncian; de dichos crímenes, 226 se cometieron contra integrantes del colectivo trans.

A pesar de que en la Ciudad esta población logró derechos para hacer concordar su identidad de género con su sexo biológico, seguía ocupando el primer lugar donde estos crímenes se cometían, seguido por el Estado de México. Hoy día, la Ciudad de México está obligada a concederle a cualquier persona que lo solicite actas de nacimiento nuevas y la primera parte del tratamiento (que es hormonal). Sin embargo, el proceso todavía tiene aristas importantes desde el punto de vista del biopoder. ${ }^{4}$

Durante dos años, las personas transexuales deben frecuentar sesiones de psicoterapia individual y en grupo, hacer análisis con regularidad, así como fonoterapia, someterse a varios tests psicológicos (el MMPI, ${ }^{5}$ el House Tree Person, ${ }^{6}$ el Rorscharch) ${ }^{7}$

4 Se refiere a las numerosas técnicas para conseguir la subsunción del cuerpo y el control de las poblaciones. Foucault se ha referido a las prácticas de biopoder cuando habla de la salud pública y la teoría del riesgo, entre otras muchas prácticas de la medicina y profesiones de la salud.

5 El Inventario Multifásico de Personalidad de Minnesota es una de las pruebas de personalidad más usadas en el campo de la salud mental. Su diseño está enfocado a la identificación del perfil de personalidad y la detección de psicopatologías.

6 El test de la casa/árbol/persona es una prueba proyectiva basada en la técnica gráfica del dibujo, por medio de la cual se realiza una evaluación global de la personalidad del individuo, su estado de ánimo, emocional, etcétera. La realización de dibujos es una forma de lenguaje simbólico que ayuda a expresar de manera bastante inconsciente los rasgos más íntimos de la personalidad.

7 El test de Rorschach, o análisis de las manchas de tinta, es una prueba proyectiva que trata de orientar al seleccionador sobre el funcionamiento psíquico del entrevistado. 
que los obligan a ir de tres a cuatro veces a la semana al hospital y los llenan de ansiedad. Llegar a la cirugía es interpretado como si hubieran aprobado los exámenes, y para muchos de ellos significa que han conseguido demostrar que son mujeres de verdad. ${ }^{8}$ Pero ¿quién se ha adjudicado el derecho de juzgar lo verdadero y lo falso en el mundo del sexo y el género?

En Quebranto vemos a Coral y a su madre preparándose para ir a dar un paseo por la ciudad; ambas se untan maquillaje, sombras, labial y comparten con la audiencia cómplice la construcción de su personaje antes de salir a la calle.

El público no puede más que cuestionarse sobre la "naturaleza" o "artificialidad" del ser mujer, más allá de la biología. La noción de performance (representación teatral) emerge en el psicoanálisis cuando Rivière definió por primera vez la feminidad justamente como mascarada. En otra acepción, performance de género es un conjunto de repeticiones ritualizadas que explican los procesos de socialización y de interiorización de normas a la manera de una representación en el teatro, porque, como todo aprendizaje, la encarnación del género se consigue escenificando maneras de ser y hacer, imitando a otros que funcionan como modelos. Ritualizando y sistematizando actos, gestos, modos y estilos es como se hacen propios los recursos de lo que en el exterior se impone como ideal.

Se va aprendiendo a ser hombre o mujer con la improvisación de actitudes a partir de probar guiones de la mascarada que "ser" femenino o masculino implica. Esto es parte de lo que clama la película en voz de Lilia, la madre.

De pronto que sale toda vestida de mujer, que ni se sabía pintar, ni sabía caminar, ni nada, y sale así completamente con alevo-

8 Esto ha ido cambiando, afortunadamente, gracias a la presión de los colectivos LGBTTTI, que han logrado, por ejemplo, que una niña trans (Sofía) sentara precedentes al cambiar de identidad por vía únicamente administrativa, sin tener que sufrir procedimientos ni médicos ni psicológicos ni tampoco pasar por un juzgado. 
sía... me dijo: "Desde este momento, soy mujer, quieras tú o no quieras". Y yo en el sillón, se me cerró así un círculo redondo que sentí que se me sumió, que no podía salir, sentí muy feo. No me quedaron palabras y entonces le dije yo: "Bueno, está bien".

Y con estas palabras se explica el proceso mediante el cual Coral adviene mujer, "aprendiendo" a caminar, vestir, andar, a ser, tal como en una representación teatral. Este juego de máscaras en el que el rey de la fonomímica imita a Raphael, hace luego personajes en el cine, se vuelve Coral Bonelli y, encarnada en ella, imita a Lucha Reyes y nuevamente a Raphael; es sólo una manifestación muy evidente del proceso que todos jugamos usando personajes y máscaras a partir de las cuales somos.

\section{LA VIDA ES RASPOSA (JORGE FONS)}

Hay otro enorme problema de salud que afecta al colectivo de la diversidad: el suicidio. La definición de la Real Academia Española (2017) asegura que suicidarse es "quitarse la vida voluntariamente", pero en muchos casos representa un homicidio indirecto que aunque utiliza el cuerpo de la víctima para perpetrarlo, no es individualmente su responsabilidad. Nadie que tenga un medio social aceptante tiene la voluntad de quitarse la vida, como se ejemplifica en el caso de Juchitán, donde los muxes, lejos de ser perseguidos, gozan de protección social, capital simbólico y prestigio social. "Yo ya estaba como en una olla de frijoles a punto de explotar, ¿no? O haces eso, o te das chicharrón ¿¿no? Al hacer esto [convertirme en Coral] perdí unas cosas y gané otras: ser yo misma. De no haber hecho esto, yo creo que ya me hubiera matado, [por eso] no me arrepiento..." (Coral).

Sabemos que no hay nada enteramente biológico que determine las causas de muerte, ni siquiera en los casos donde hay, como en el caso de Coral, un diagnóstico de enfermedad crónica 
como la diabetes. La medicina $\operatorname{social}^{9}$ ha demostrado que a pesar de que salud pública tienda a responsabilizar a los individuos de sus problemas de salud, centrando su prevención en la promoción de estilos de vida saludables y el cambio de conductas individuales, ${ }^{10}$ la distribución, complicaciones y letalidad de los problemas de salud — desde la diabetes hasta el suicidio - están determinadas socialmente, pues ¿cómo saber, por ejemplo, qué calidad de vida tendría Coral si no fuera discriminada en los servicios de salud por su condición trans?

Un estudio realizado por el Instituto Nacional de Salud Pública reveló que de 370 profesionales de la salud (131 hombres y 239 mujeres), una cuarta parte piensa que la homosexualidad es causa de sida en México; más del 25\% dijo que no compartiría una casa con un homosexual, y casi tres cuartas partes opinaron que las personas viviendo con VIH son culpables de su condición. Ojalá llegue un día en que tener que ir a un médico de salubridad no sea sinónimo de maltrato. Hoy en día: desmantelados, desfinanciados y olvidados por el Estado neoliberal, depender del sistema público de salud en México representa estar en riesgo de muerte. A la poca calidad, disponibilidad y accesibilidad de los servicios de salud se le tiene que agregar la ignorancia del personal de salud del país, que prefiere no tratar con personas

9 Que tiene sus orígenes en Europa, a mediados del siglo XIX, con los postulados de Neumann y Virchow, quienes planteaban que la mayor proporción de enfermedades se debe a las condiciones sociales en que se desarrolla la población y que, por lo tanto, la investigación científica debía orientarse a clarificar la relación entre tales condiciones y los problemas médicos.

10 La publicidad oficial sobre la diabetes en México se centra en difundir un discurso común: la responsabilidad sobre la propia salud, ejemplificada en el control del peso corporal, y promoviendo prácticas que pueden no ser alcanzables (como beber agua potable embotellada, cuando es más cara que las bebidas azucaradas, o realizar actividad física, sin considerar jornadas laborales, tiempos de traslados, disponibilidad de espacios y equipamiento). RojasRajs, Soledad, "La diabetes en la publicidad oficial para la televisión mexicana: problemas y límites para la comunicación en salud", Revista Salud Problema, México, segunda época, año 10, enero-junio de 2013. 
del colectivo LGBTTTI porque son supuestos portadores de enfermedades contagiosas.

Como casi todo en la vida de Coral, sus sufrimientos no expresan sólo una problemática individual, sino las injusticias que aquejan al conjunto de su comunidad; por ejemplo, con la falta de garantía del derecho a un empleo digno y formal otorgado de acuerdo con sus habilidades y conocimientos: "Agarré la prostitución porque ¿quién me va a dar trabajo ahorita a los 48 años?”.

Gran parte de la población transexual, travesti y transgénero se encuentra desempleada y rechazada abiertamente por su condición trans; suelen tener empleos precarios y su situación laboral es sumamente conflictiva: el conocimiento de su transexualidad es causa en muchos casos de acoso laboral por parte de los jefes, compañeros o clientes. En las oficinas dedicadas a gestionar recursos humanos no admiten cambios en el nombre, aun si éste ha ocurrido ya por corrección al acta de nacimiento o por reasignación sexual, por lo que muchas se ven presionadas para ejercer la prostitución.

Coral Bonelli simboliza la viva imagen de una persona que, habiendo podido ser "fuerte y alta" como un pino, se quedó truncada cuando fue desestimada por la historia, no por falta de talento sino por una lógica que sigue priorizando ideas estereotipadas y rígidas de identidad sexual, por sobre la libertad, la salud, el valor y la capacidad. Ojalá y como sueña en voz alta Jorge Fons, la imagen del cambio radical que dio Coral a su cuerpo-territorio y vida sea un ejemplo de que el mundo también puede permitirse cambios verdaderos, dignos de un "triple mortal". Sin este salto no parece haber demasiada esperanza en el "ring".

\section{BIBLIOGRAFÍA}

Alves De Melo Bento, Berenice, "Cuerpo, performance y género en la experiencia transexual", Anuario de Hojas de Warmi, España, núm. 13, 2002, disponible en: http://revistas.um.es/hojasdewarmi/article/viewFile/166211/144751. 
Caparros, Martín, La Crónica, Buenos Aires, Planeta, 2016.

De Beauvoir, Simone, El segundo sexo, Buenos Aires, Siglo XXI, 1981.

DE LA MADRID, Ricardo (coord.), Reporte sobre la discriminación en México 2012, México, Conapred-CIDE, disponible en: http://

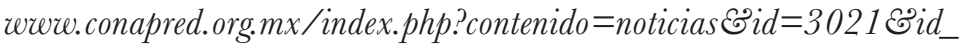
opcion $=108 \mathcal{E}^{2} p=214$.

FIEScO, Roberto (dir.), Quebranto [película], México, Mil NubesCine, Fondo para la Producción Cinematográfica de Calidad, Ruta 66, Centro Universitario de Estudios Cinematográficos, Fondo Nacional para la Cultura y las Artes, 2013.

Hernández, Pedro, Performatividad y medicalización en mujeres trans de la Ciudad de México: un acercamiento a través de sus vivencias, tesis de maestría, México, Universidad Autónoma MetropolitanaUnidad Xochimilco, 2016.

Maristain, Mónica, "Entrevista a Jorge Fons", Sin Embargo, México, febrero de 2014, disponible en: http://www.sinembargo. $m x / 02-02-2014 / 887213$.

PANTOJA, Sara, "México, segundo lugar en crímenes por homofobia", Proceso, México, mayo de 2015, disponible en: http://wrere. proceso.com.mx/403935/mexico-segundo-lugar-mundial-en-crimenespor-homofobia.

PISANTY, Julio, "Noticias de salud: salud de nuestros pueblos", Boletín de la Asociación Latinoamericana de Medicina Social, México, núm. 2, septiembre-octubre de 2016.

Preaiado, Beatriz, "Género y performance", Tres episodios de un cybermanga feminista queer trans, España, 2011, disponible en: http:// wrwe.cpp.panoramafestival.com/wp-content/uploads/2011/08/BP_ Genero-y-Performance_ESP.pdf.

ROJAS-RAJS, Soledad, "La diabetes en la publicidad oficial para la televisión mexicana: problemas y límites para la comunicación en salud", Revista Salud Problema, México, segunda época, año 10, enero-junio de 2013. 
Esta obra forma parte del acervo de la Biblioteca Jurídica Virtual del Instituto de Investigaciones Jurídicas de la UNAM www.juridicas.unam. $\mathrm{mx}$ https://biblio.juridicas.unam.mx/bjv

Libro completo en: https://goo.gl/sHxaH7

\section{RECONOGER EL PASADO: EL LUGAR DE LA ADULTEZ EN UN MUNDO DIVERSO}




\title{
EL SEGTOR MÁS IMPORTANTE Y MAYORITARIO EN LA POBLACIÓN MUNDIAL EN 40 AÑOS: PERSONAS ADULTAS MAYORES
}

\author{
Karla Margarita ORTIZ ANTUNA
}

El viejo no puede hacer lo que hace un joven; pero lo que hace es mejor.

GICERÓN

\begin{abstract}
SUMARIO: I. Las personas adultas mayores: por primera vez el sector mayoritario de la población mundial. II. Convención Interamericana sobre la Protección de los Derechos Humanos de las Personas Mayores: retos. III. Mujeres adultas mayores.

IV. Bibliografia.
\end{abstract}

\section{LAS PERSONAS ADULTAS MAYORES: POR PRIMERA VEZ}

EL SECTOR MAYORITARIO DE LA POBLACIÓN MUNDIAL

De acuerdo con el último censo (2010), hay 112,336,538 personas en México, de las cuales 10,055,379 son personas adultas mayores, es decir que tienen más de 60 años, edad a partir de la cual se les denomina personas adultas mayores (PAM).

El problema recae cuando este sector de la población es visto como beneficiario de programas y dádivas sociales, y no siempre como verdaderos sujetos de derechos y protagonistas del desarrollo, que, frente a una cohesión social visible, sean jóvenes, niños, personas adultas mayores o mujeres adultas mayores, causan un 
resquebrajamiento al solicitar la erradicación de la desigualdad y la discriminación.

Con ello, la esperanza de vida también se vuelve un factor muy importante para tener sobre la mesa; al aumentarse ésta hay un crecimiento acelerado de esta población en particular, para lo que no se tiene en cuenta el tipo de vida, calidad y dignidad, causando un estado momentáneo de alarma, sí, porque de nuevo no se está preparado para un país, ciudad o colonia que prevenga desde ahora aspectos mínimos como el reparo a medidas esenciales como las rampas en las calles de una ciudad o el simple conocimiento y acceso a la información para las PAM.

Uno de los aspectos más importantes en la etapa de desarrollo de las PAM es el deterioro de sus capacidades funcionales, emocionales y cognitivas. Éstas, junto con las enfermedades crónico-degenerativas, limitan la realización de las actividades diarias y necesarias para la vida de las personas. ${ }^{1}$

Otro punto a favor de porqué este grupo de población marginada y discriminada debe visibilizarse, son los resultados materiales arrojados en la Encuesta Nacional de Ingresos y Gastos de los Hogares (ENIGH) 2016, en donde se señala que en el país hay 33.5 millones de hogares, y en el 30.1\% de éstos reside al menos una persona de 60 años y más. Es aterrador desde que se lee hasta que se sabe que no hay políticas públicas que se refieran a la regulación de esta "futura crisis de los 2017".2

En la actualidad, las personas con este rango de edad en el continente americano representan el 14\% del total de la población del hemisferio (más de 135 millones de personas). En 2030, cerca de dos de cada cinco personas tendrán 60 o más años, y en total habrá más de 215 millones de personas mayores en el conti-

1 Mautone Acle, Marcos, "El principio de igualdad y no discriminación en la vejez y la introducción de la perspectiva de edad", en Huenchuan (ed.), Los derechos de las personas adultas mayores en el siglo XXI: situación, experiencias y desafios, México, CEPAL, p. 63.

2 INEGI, Encuesta Nacional de Ingresos y Gastos de los Hogares, México, 2016. 
nente americano. En 2015 se creó la Convención Interamericana sobre la Protección de los Derechos Humanos de las Personas Mayores, la cual permitirá reforzar las obligaciones jurídicas de respetar y promover los derechos de esta población. Su ratificación conllevará la obligación de los Estados parte de adoptar medidas a fin de garantizar a la persona mayor un trato digno en todos los ámbitos. ${ }^{3}$

Por otro lado, y teniendo conciencia del debido y para nada planeado aumento proyectado del número de PAM en el país, se incrementarán las necesidades de salud para este sector de la población, así como una llamada de alerta de uno de los problemas más temidos de la vejez: la dependencia funcional. La importancia de este problema se deriva de las consecuencias que conlleva, entre las que destacan:4

1) Las de carácter personal (disminución de autoestima y autopercepción de su bienestar).

2) Las de carácter familiar (cambio de rutinas y relaciones entre integrantes de la familia).

3) La prestación de cuidados especiales.

4) El desgaste emocional y físico del cuidador.

5) La institucionalización.

6) Las implicaciones económicas a nivel individual, familiar, social y de políticas de salud. ${ }^{5}$

Entonces, este sector de la población se vuelve tan importante dado que es un grupo que pesa y que es significante, que hace cambiar desde cosas mínimas, como las calles, hasta la creación de una Convención Interamericana, primera en su tipo, en defensa de los derechos de este sector de la población.

3 Comunicado de prensa C-198/1, “América se convierte en la primera región del mundo en contar con una convención para la protección de los derechos de las personas mayores", disponible en: http://wwwo.oas.org/es/centro_noticias $/$ comunicado_prensa.asp.? $\operatorname{Codigo}=C-198 / 15$ [fecha de consulta: 12 de noviembre de 2017].

4 INEGI, Encuesta Nacional sobre Salud y Envejecimiento en México, 2015.

5 Idem. 
Así, hace recurrir a las cuestiones siguientes: ¿finalmente no son los que toman las decisiones? Claro, ¿derivado de la apatía de los jóvenes o aún peor de las pocas o nulas opciones para elegir desde el ámbito político y electoral? $\mathrm{O}$ de los que incluso existen pensando que no son considerados como una fuente de economía, en un espacio donde ellos son una mayoría que concentra gran cantidad de dinero, dinero por el cual han trabajado toda su vida, por ejemplo las pensiones. Entonces, ¿qué esperamos para las nulas políticas implementadas? Tal vez que el tiempo nos alcance y entonces, y sólo entonces, hacer algo con el problema ya radicado.

\section{CONVENGIÓN INTERAMERICANA SOBRE LA PROTECGIÓN DE LOS DERECHOS Humanos de las Personas MaYORES: Retos}

[Persona mayor es] aquella de 60 años o más, salvo que la ley interna determine una edad base menor o mayor, siempre que esta no sea superior a los 65 años. ${ }^{6}$

Tras años de intensas negociaciones intergubernamentales, la Convención Interamericana sobre los Derechos de las Personas Mayores fue aprobada el 15 de junio de 2015. Hasta el momento, seis países la han firmado: Argentina, Brasil, Bolivia, Costa Rica, Chile y Uruguay, de los cuales Costa Rica y Uruguay la han ratificado y depositado, de acuerdo con los procedimientos establecidos, gracias a los cuales ha sido puesta en efecto en ambos países.

Se ha visto que en el derecho internacional de los derechos humanos se han creado diversos mecanismos de defensa o incluso de promoción de estos derechos, pero la más actual es, sin

6 Artículo 2o., Convención Interamericana sobre la Protección de los Derechos Humanos de las Personas Mayores, 2015. 
duda, la ya famosa Convención Interamericana sobre la Protección de los Derechos Humanos de las Personas Mayores.

La importancia de este instrumento recae cuando la Convención, en el artículo 32, en el apartado Toma de conciencia, menciona la adopción de medidas para lograr una divulgación y capacitación de toda la sociedad, como: fomentar un trato digno y respetuoso hacia las personas mayores, así como su empoderamiento y la erradicación de los estereotipos sobre la vejez; promover la inclusión de contenidos que propicien la comprensión y aceptación de la etapa del envejecimiento, así como el reconocimiento de la experiencia, la sabiduría, la productividad y la contribución al desarrollo que la persona mayor brinda a la sociedad en su conjunto.

Se hace mención de un mecanismo de seguimiento, que aún no está constituido dado que se debe esperar que el décimo país ratifique o se adhiera. Contiene un órgano para ser la Conferencia de Estado parte, sin embargo, ésta entrará en vigor y se realizará por primera vez después de los noventa días de haberse constituido el mecanismo de seguimiento, en la cual se establecerán todas las reglas, la metodología y la elección de sus autoridades; después del primer año se deberán presentar informes cada cuatro años.

Guenta también con un sistema de peticiones individuales, en donde cualquier persona o grupo de personas puede presentarlo ante la Comisión Interamericana de Derechos Humanos, independientemente de si se haya o no reconocido la competencia de la Corte Interamericana de Derechos Humanos.

El objetivo de la Convención "... es ser un instrumento regional jurídicamente vinculante que promueva, proteja y asegure el pleno goce y ejercicio de los derechos humanos de las personas mayores, a fin de contribuir a su plena inclusión, integración y participación en la sociedad". ${ }^{7}$

Establece que los Estados tendrán la obligación de adoptar medidas para prevenir, sancionar y erradicar prácticas que cons-

\footnotetext{
7 Ibidem, proemio.
} 
tituyan malos tratos o penas crueles, inhumanas o degradantes que atenten contra la seguridad e integridad de la persona mayor. ¿Cuáles son estas prácticas? Aislamiento, abandono, hacinamiento, expulsiones de la comunidad, negación de nutrición, tratamientos médicos inadecuados o desproporcionados, entre otras. Todo esto para decir que hasta ahora debemos afrontar la protección de los derechos desde la otredad y eliminar la visión asistencialista.

Entre las premisas de la Convención se encuentran la no discriminación por edad, garantizar oportunidades de trabajo y educación, reconocer su derecho a la salud, a la alimentación y a tener una familia, ya que muchos viven en el abandono; ello traerá como consecuencia el abrir espacios para vivir en sociedad y que tengan acceso a una certeza jurídica.

Cuando México ratifique la Convención será entonces el turno del Poder Legislativo para modificar y tomar las medidas necesarias para despertar estos derechos. Así, la firma y ratificación de ese instrumento internacional ampliará y fortalecerá el marco jurídico de protección de los derechos de las personas adultas mayores; obligará a los legislativos federal y estatales a armonizar las leyes para que se garanticen. ${ }^{8}$

Así, como dijo la coordinadora de Gerontología del Instituto para la Atención de los Adultos Mayores de la Ciudad de México, Ana Gamble Sánchez-Gavito, en el marco del Seminario Diversidades, "sólo 38 por ciento de la población adulta mayor

8 CNDH, Comunicado de prensa DGG/240/17, Ciudad de México, 20 de julio de 2017. "El paradigma garantista de envejecimiento debe superar la visión asistencialista que identifica a las personas adultas mayores únicamente como receptoras pasivas de programas sociales, para estar en posibilidad de consolidar que la línea conductora de los planes de trabajo de las instituciones estatales sea el enfoque basado en sus derechos, y cuyas metas se ajusten a los objetivos de desarrollo sostenible fijados en la Agenda 2030 de Naciones Unidas enfocados en ese grupo poblacional, como lo son garantizar la seguridad en el ingreso y en el acceso a servicios de salud; incrementar sus oportunidades de empleo y aprendizaje; lograr la igualdad de género, proveerles de viviendas y transportes seguros, y eliminar la violencia en su contra". 
tiene acceso a una pensión, por lo que se requiere apoyar a quienes no cuentan con este derecho".

Poco a poco, se irán adoptando las medidas necesarias que hagan que se conviertan en protagonistas de su propio proceso de envejecimiento; entre ellos, la implementación de mecanismos para la participación democrática y plural. El ombudsman nacional, Luis Raúl González Pérez, tras informar que en el país están por concluir las consultas con las dependencias del Ejecutivo Federal y organizaciones de la sociedad civil especializadas en el tema, llamó a intensificar las respuestas para que la Secretaría de Relaciones Exteriores (SRE) inicie los trámites para su firma y ratificación, lo que permitirá ampliar la protección de los derechos de las personas adultas mayores.

Si se tiene en cuenta que un tratado es un acuerdo celebrado entre Estados que, una vez que ha entrado en vigencia, genera una serie de obligaciones que los países deben incorporar a la normatividad interna, en el caso de la Convención Interamericana sobre la Protección de los Derechos Humanos de las Personas Mayores, estas obligaciones se presentan como un catálogo de derechos que deben ser garantizados a todos los ciudadanos mayores de 60 años de los Estados que sean parte de dicho tratado.

A grandes rasgos, los tratados internacionales tienen dos etapas fundamentales:

1) La internacional, que se rige por la Convención de Viena sobre el Derecho de los Tratados.

2) La nacional, regida por la Constitución política de cada país. De aquí podría seguir hablando sobre el bloque de constitucionalidad y convencionalidad, pero esto, por ahora, es harina de otro costal.

Esto se oye fácil, pero si se tiene en cuenta que ratificar una convención implica de manera directa que el Estado que la firma y ratifica tiene obligaciones casi de facto, es entonces cuando los Estados la piensan dos veces, y México la piensa tres veces más, ya que hasta la fecha sólo los siguientes países la han adoptado, algunos otros firmado y unos menos ratificado. En este sentido, 
se tienen tres etapas para la "aceptación de un tratado": la negociación y redacción, la firma y la ratificación.

\begin{tabular}{|l|l|l|l|}
\hline \multicolumn{1}{|c|}{ País } & \multicolumn{1}{|c|}{ Firma } & \multicolumn{1}{c|}{ Ra/Ac/Ad } & \multicolumn{1}{c|}{ Depósito } \\
\hline Argentina & $\begin{array}{l}15 \text { de junio } \\
\text { de } 2015\end{array}$ & $\begin{array}{l}30 \text { de junio de } \\
2017\end{array}$ & $\begin{array}{l}23 \text { de octubre de 2017 } \\
\text { (con sus respectivas reser- } \\
\text { vas) }\end{array}$ \\
\hline Bolivia & $\begin{array}{l}9 \text { de junio de } \\
2016\end{array}$ & $\begin{array}{l}13 \text { de marzo } \\
\text { de } 2017 \text { (RA) }\end{array}$ & 17 de mayo de 2017 \\
\hline Brasil & $\begin{array}{l}15 \text { de junio } \\
\text { de } 2015\end{array}$ & - & - \\
\hline Chile & $\begin{array}{l}15 \text { de junio } \\
\text { de } 2015\end{array}$ & $\begin{array}{l}11 \text { de julio de } \\
2017\end{array}$ & $\begin{array}{l}15 \text { de agosto de 2017 (con } \\
\text { sus respectivas reservas) }\end{array}$ \\
\hline Costa Rica & $\begin{array}{l}15 \text { de junio } \\
\text { de } 2015\end{array}$ & $\begin{array}{l}12 \text { de octubre } \\
\text { de } 2016 \text { (RA) }\end{array}$ & 12 de diciembre de 2016 \\
\hline Uruguay & $\begin{array}{l}15 \text { de junio } \\
\text { de } 2015\end{array}$ & $\begin{array}{l}7 \text { de } \\
\text { noviembre de } \\
2016(\text { RA) }\end{array}$ & 18 de noviembre de 2016 \\
\hline
\end{tabular}

La negociación es la etapa que incluye todas las discusiones, preparaciones previas, juntas para establecer los puntos de disidencia entre los Estados firmantes, y esta etapa a su vez concluye con la redacción del "acuerdo" (los artículos propiamente). La firma, por su lado, es la aceptación maternizada como tal de los Estados, aceptación que implica que están de acuerdo con el texto. La ratificación es un "trámite", en donde adquiere de manera fáctica las obligaciones de carácter internacional que, en el caso particular de México, el Senado debe aprobar, ejerciendo así el poder de control constitucional.

Finalmente, el presidente envía una nota diplomática a la Secretaría General de la Organización de Estados Americanos (OEA) (para el caso de la Convención sobre Personas Mayores), en la que informa que su país ha ratificado ser parte del tratado. 
Si cumple con todos estos requisitos se puede decir que un Estado es parte, requisitos que a su vez implican, incluso, cambiar toda la maquinaria legislativa; con ello, no hay que olvidar la ya famosa jurisprudencia de la Suprema Corte de Justicia de la Nación que establece que todas las sentencias de la Corte Interamericana serán vinculantes para México, sea parte o no de alguna Convención que no haya ratificado. Es allí cuando se podría decir que un Estado es parte, en específico, de esta Convención.

¿Qué se espera para que México la firme? Exacto, ya sabemos que no es fácil, sí, pero si se tiene en cuenta que México es el país que más tratados sobre derechos humanos ha firmado en el mundo, con una suma aproximada de $2010,{ }^{9}$ y como consecuencia mucho se le ha criticado, pues ha firmado sin saber cuáles son los pies y cabeza, y además los ha ratificado, ahora resulta que México ha decidido ponerse estricto con sus decisiones; si se ve desde el punto de vista de que sabe cuáles son las verdaderas implicaciones que trae aparejada esta Convención, entonces también se puede decir que incluso el Estado mexicano ya estará pensando cómo y sobre cuáles leyes hará las respectivas modificaciones.

La apuesta es, entonces, visibilizar a esta diversidad que está inmersa en un grupo vulnerable que necesita planeación y planificación, implementación de la independencia, participación, cuidados, autorrealización y dignidad. Para que esto permita erradicar algo que puede ser incluso más relevante: la diferencia de género que se presenta en esta edad. Esto da pauta a la tercera disertación.

\section{MUJERES ADULTAS MAYORES}

Otro tema a evaluar es que, como resultado de la esperanza de vida que se tiene en el país, ésta se incrementó a una edad pro-

9 Lista de tratados internaciones en materia de derechos humanos, disponible en: http://wrww2.scjn.gob.mx/red/constitucion/TI.html\#DE_CARACTER_GENE$R A L$ [fecha de consulta: 15 de noviembre de 2017]. 
medio de 75 años. En 2012, los varones tenían una esperanza de vida de 73 años, y las mujeres de 78 años, y si a esto le sumamos el atinado dato que proporciona Ana Gamble cuando habla sobre la tasa general de fecundidad, que es de 1.7 hijos por mujer, indica que está por debajo del reemplazo intergeneracional. ${ }^{10}$

Conforme a las proyecciones que estima el Consejo Nacional de Población (Conapo), en 2017 residen en el país 12,973,411 personas de 60 y más años, de las cuales $53.9 \%$ son mujeres y $46.1 \%$ son hombres. Cabe señalar que una cuarta parte de los adultos mayores $(24.3 \%$ ) reside en localidades menores de 2 mil 500 habitantes. Si se considera que la población tiene una mayor esperanza de vida (75.3 años para 2017) y la fecundidad es cada vez menor (2.21 hijos por mujer), entonces el peso relativo de los adultos mayores toma mayor relevancia en la estructura por edad. Entre 1970 y 1990, el porcentaje de adultos mayores respecto a la población total pasó de $5.6 \%$ a 6.2\%; para 2017 dicho porcentaje fue de $10.5 \%$, y de acuerdo con la Organización de las Naciones Unidas, su tendencia esperada en los próximos años la colocan como una de las transformaciones sociales de mayor trascendencia del siglo XXI. ${ }^{11}$

Un aspecto que vulnera a las personas de edad es no tener un apoyo al interior del hogar, peor aún de su hogar. En el país hay 1.6 millones de personas de 60 y más años que viven solas, y la mayoría son mujeres (63\%). Otro aspecto que vulnera a los hogares con al menos un adulto mayor es que su único ingreso proviene de una o varias personas que tienen 60 y más años: $37.1 \%$ (3.7 millones) de estos hogares cumple con dicha condición.

La apuesta principal de este apartado es dejar una pregunta abierta, es decir, arrojar datos, alarmar, generar problemática para que se comience a tener en cuenta, primero, a las personas adultas mayores y, segundo, a las mujeres adultas mayores. Y así

10 INEGI, Censo de Población y Vivienda 2010, México.

11 Organización de las Naciones Unidas (ONU), "Envejecimiento", disponible en: http://wwwe.un.org/es/sections/issues-depth/ageing/index.html [fecha de consulta: 6 de junio de 2017]. 
como en repetidas veces Lucía Raphael de la Madrid menciona, efectivamente, este sector es un grupo vulnerado, pero si a eso le sumamos que son mujeres, significa que es un sector que padece una discriminación variada, múltiple. Ya muchos han asentado que es de la mayor relevancia que los encargados de la elaboración de esas acciones consideren el género como un factor que incide en el acceso a los derechos de las personas adultas mayores, ya que se ha evidenciado que las mujeres mayores enfrentan condiciones de desventaja social y económica frente a los hombres, incluso están expuestas a padecer discriminación múltiple cuando pertenecen a un pueblo o comunidad indígena, se encuentran en condiciones de pobreza o padecen alguna discapacidad, entre otras.

\section{BIBLIOGRAFÍA}

"Argumentos y vías para la ratificación de la Convención Interamericana sobre Personas Mayores", disponible en: http://wrwe. cuidadospaliativosdh.org/archivos/argumentos.pdf [fecha de consulta: 14 de noviembre de 2017].

Censo de Población y Vivienda 2010, México, INEGI.

Encuesta Nacional de Ingresos y Gastos de los Hogares, 2016, México, INEGI.

Encuesta Nacional sobre Saludy Envejecimiento en México, 2015, México, INEGI.

Huenchuan, Sandra, Los derechos de las personas mayores en el siglo XXI: situación, experiencias y desafios, Naciones Unidas, CEPAL, 2012.

Lista de tratados internaciones en materia de derechos humanos, disponible en: http://wrwr2.scjn.gob. $m x /$ red/constitucion/TI. html\#DE_CARACTER_GENERAL.

Organización de LAS NAGiOnes UnidAS, "Envejecimiento", disponible en: http://wrwre.un.org/es/sections/issues-depth/ageing/ index.html [fecha de consulta: 6 de junio de 2017]. 
Esta obra forma parte del acervo de la Biblioteca Jurídica Virtual del Instituto de Investigaciones Jurídicas de la UNAM www.juridicas.unam. $\mathrm{mx}$ https://biblio.juridicas.unam.mx/bjv

Libro completo en: https://goo.gl/sHxaH7

\section{GRUPOS INDÍGENAS Y MEDIOS DE COMUNICACIÓN AUTÓNOMOS}




\title{
POLÍTICAS DE EXCLUSIÓN EN EL USO DE LOS MEDIOS DE COMUNICACIÓN HACIA LOS PUEBLOS INDÍGENAS
}

\author{
Viviana PINEDA PARTIDA
}

\begin{abstract}
SUMARIO: I. La dominación histórica de los pueblos indígenas en México. II. La imposición cultural hacia los pueblos indígenas. III. Uso de la radio por parte de comunidades indígenas. IV. Situación legal de las radios comunitarias indígenas. V. Criminalización de las radios indígenas. VI. Las radios libres indígenas. VII. Conclusión. VIII. Bibliografia.
\end{abstract}

México es uno de los países con mayor diversidad cultural a nivel mundial. Reúne en una décima parte de su población y una quinta parte de su territorio a 68 pueblos indígenas, con historia, identidad y lengua propias. A pesar de esta riqueza, las etnias originarias han sido histórica y sistemáticamente explotadas, despojadas, marginadas y excluidas del resto de la sociedad.

El discurso oficial actual de inclusión pluricultural es disonante con las condiciones en que viven los pueblos originarios. Esto debido a que el respeto a su cultura, autonomía y territorio resultan incompatibles con el proyecto de Estado neoliberal, que favorece al capital global por la vía del despojo. Desde esta crítica se busca dar cuenta del reforzamiento del dispositivo de dominación hacia los pueblos originarios, el cual se extiende estratégicamente al ámbito político-cultural, en el que se les excluye del acceso a los medios de comunicación. 


\section{LA DOMINACIÓN HISTÓRICA DE LOS PUEBLOS INDÍGENAS EN MÉXICO}

En el periodo colonial las etnias fueron esclavizadas y desplazadas mediante las figuras de la encomienda y la repartición. La Independencia, que significó una cuota inmensa de sangre indígena, no incluyó a este sector en sus beneficios sociales. La primera Constitución desconoció sus usos y costumbres y les impuso una legislación basada en principios europeos. La Revolución y la Constitución de 1917 escucharon sus demandas territoriales, pero negaron la pluriculturalidad y excluyeron a los pueblos indígenas de la conformación política y legal del país. El modelo integracionista fue también etnocida, pues planteó que para el logro del progreso nacional se debía conformar al país a una misma identidad, una sola cultura y una sola lengua.

Hacia finales del siglo XX la resistencia indígena, que permitió su sobrevivencia cultural a lo largo de cinco siglos, logra por primera vez poner en la agenda pública sus demandas de autonomía y de respeto a sus derechos territoriales, económicos, políticos, sociales y culturales. Sin embargo, esas demandas asentadas en los Acuerdos de San Andrés Larráinzar no se han cumplido hasta hoy.

El dispositivo de dominación instalado desde la Colonia se ha ido modificando para mantener el despojo y la explotación de los pueblos originarios. Actualmente, las reformas constitucionales en materia indígena reconocen la pluriculturalidad y el derecho a la libre determinación; sin embargo, el marco legal, político e institucional vigente no permite su reconocimiento y ejercicio efectivos.

En la práctica, persiste la sujeción legal de estos pueblos a una hegemonía cultural mestiza, racista y discriminadora que violenta todos sus derechos "sobre las tierras, territorios y recursos; a la autonomía y libre determinación; a determinar sus prioridades de desarrollo; a la consulta y consentimiento libre, previo e informado; a una vida libre de violencia y de impunidad y con 
acceso a la justicia". ${ }^{1}$ Asimismo, "los llamados derechos económicos, sociales y culturales - a la alimentación, salud, educación, vivienda digna, vestido, trabajo, lengua - son quebrantados por gobiernos (en sus tres niveles y en sus tres poderes), empresas y crimen organizado". ${ }^{2}$

Renovadas formas de paternalismo y asistencialismo buscan subsanar la discriminación estructural que ha llevado a estos pueblos a la marginalización social por la vía de la violación sistemática de sus derechos. Pueblos que en la actualidad se enfrentan a la devastación de sus territorios y culturas por la imposición de megaproyectos extractivistas; al desplazamiento por devastación y violencia, y a la criminalización como factor común al exigir el respeto a sus derechos.

\section{LA IMPOSICIÓN CULTURAL HACIA LOS PUEBLOS INDÍGENAS}

La política de exterminio hacia los pueblos indígenas ha adquirido un componente cultural fundamental. La imposición y homogeneización cultural buscan la negación de su diversidad y la colonización de los sistemas simbólicos construidos a lo largo de una historia milenaria.

A través de los medios de comunicación de masas se busca fortalecer los prejuicios dominantes para imponerlos como modelos de pensamiento únicos. Se genera una negación del valor de la diferencia, y ésta se usa y se potencia para justificar la opresión y el despojo. Los medios buscan la legitimación de las políticas de dominación del indígena vía la difusión de una imagen símil del retraso, de lo ignorante y primitivo que se niega al progreso, que requiere de asistencia paternalista y que está muy lejos de considerarse sujeto de derechos.

1 Declaración de cierre de misión de la Relatora Especial de las Naciones Unidas sobre los Derechos de los Pueblos Indígenas, Victoria Tauli-Corpuz.

2 Idem. 
Cabe recordar que México es un país en donde lo diverso es prejuiciado e invisibilizado en los principales medios, que son la televisión y la radio. El primero de ellos está controlado en el 94\% por dos grupos empresariales; el segundo pertenece en el $47.8 \%$ a cuatro cadenas concesionarias. ${ }^{3}$

El acceso de los grupos indígenas a los medios de comunicación es prácticamente nulo en la televisión, y en la radio los espacios que se han abierto, con las 30 estaciones a cargo del Instituto Nacional Indigenista (INI), renombrado Comisión Nacional para el Desarrollo de los Pueblos Indígenas (CDI), han estado fuertemente mediadas por mecanismos de control oficial y han fungido como espacios de legitimación de las políticas nacionales en materia indígena.

La concentración y privatización de los medios en el país toma gran relevancia en el contexto capitalista actual, pues éstos se han tornado en las instituciones culturales más apropiadas para que las clases en el poder produzcan, hagan circular e inculquen su postura de clase como ideología predominante, ${ }^{4}$ que es la neoliberal. En este sentido, los medios privados buscan invisibilizar a aquellas voces que puedan ser críticas hacia las condiciones de dominación y desigualdad que vivimos la mayoría de la población, entre ellas las de los pueblos indígenas.

En contraparte, estos medios se encargan de homogeneizar el pensamiento, orientar las acciones hacia el consumo y dirigirlas por los márgenes permitidos para mantener la estabilidad política y económica del sistema social basado en la acumulación por desposesión. Por lo tanto, los medios privados son las herramientas culturales del libre mercado en los que la información se transforma en una mercancía inserta en la reproducción del capital, regida por la competitividad y la ganancia.

3 Carmen Aristegui, Primera Emisión, México, Noticias MVS, 25 de octubre de 2011.

4 Esteinou Madrid, Javier, Los medios de comunicación y la construcción de la hegemonía, México, Trillas, 1992, p. 20. 
La lógica mercantil y oficialista que domina a los medios en México vulnera los derechos a la libre expresión y niega el acceso democrático, la participación, la diversidad y la pluralidad. Esta situación es grave, pues a través de ellos se construye "la principal conciencia colectiva que relaciona a los individuos con la sociedad", ${ }^{5}$ y son fundamentales en las prácticas y las políticas de la representación humanas.

La carencia de representación y participación en los medios masivos y oficiales de las culturas indígenas y sus problemáticas operan como un mecanismo más de colonialidad del poder. Ante ello muchas comunidades han acompañado la lucha de sus derechos con ejercicios de autonomía mediática que en muchos casos han sido reprimidos fuertemente, incluso con el asesinato de sus colaboradores.

\section{USO DE LA RADIO POR PARTE DE COMUNIDADES INDÍGENAS}

Ante las lógicas de enunciación hegemónicas en los medios masivos y oficiales y la falta de representatividad en ellos, muchos pueblos indígenas han desarrollado estrategias de comunicación comunitaria que sirven como mecanismos de socialización y representación de sus culturas. La apropiación de estos medios busca la defensa de sus sistemas simbólicos a través del ejercicio del derecho a la información, a la libertad de expresión y al acceso a la información; además de que fungen como herramientas de articulación de las luchas por la autonomía, la autodeterminación y el reconocimiento de los derechos colectivos de los pueblos.

Dentro de las experiencias de comunicación indígena destaca el uso de la radio como medio privilegiado por las comunidades. La predilección por la radio responde en parte a su eficaz rango de cobertura en regiones rurales y a que es una tecnología relativamente económica para quien la opera y la escucha. Un

$5 \quad$ Esteinou Madrid, Javier, op. cit., p. 46. 
aspecto fundamental de estas emisoras es la reivindicación del ejercicio a la comunicación en su lengua propia, como elemento nodal de su identidad, que ha sido avasallado históricamente por el castellano, lengua única con que se expresan los medios masivos.

La radio permite el ejercicio de la tradición oral que ha sido fundamental en los procesos de resistencia cultural de los pueblos indígenas y hace accesible sus contenidos en comunidades con índices de analfabetismo altos.

A diferencia del carácter homogeneizante y generalizante de los principales medios, las radios comunitarias tienen la capacidad de informar desde el contexto local las condiciones cotidianas de los pueblos de acuerdo a sus propias necesidades y según su propia cultura y cosmovisión.

Una especificidad de estas emisoras "tiene que ver esencialmente con el proceso organizativo que está detrás de la radio y con los vínculos que ésta establece con la comunidad en la que transmite". ${ }^{6}$ Es decir que cumple una función social en beneficio de una comunidad, misma que participa desde su instalación hasta la construcción de los contenidos de los programas. La mayoría de las radios son autogestionadas por las comunidades donde operan y su legitimidad está fundamentada en el ejercicio de su autonomía.

\section{SITUAGIÓN LEGAL DE LAS RADIOS COMUNITARIAS INDÍGENAS}

Desde finales del siglo XX hasta la actualidad han emergido aproximadamente 200 radios comunitarias e indígenas en el país, impulsadas desde los pueblos. Un gran porcentaje de éstas operan fuera de la normatividad oficial.

6 Gasparello, Giovanna, "No morirá la flor de la palabra... la radio comunitaria indígena en Guerrero y Oaxaca", Revista Nueva Antropología, México, vol. XXV, núm. 77, julio-diciembre de 2012, p. 138. 
Cabe destacar que hasta 2014 sólo existían dos figuras legales para las 2,4617 estaciones de radio en el país: las concesionarias, con fines de lucro, y las permisionadas, financiadas por las instituciones del Estado, como gobiernos estatales o universidades públicas. Dentro de esta última categoría se incluían marginalmente a veinte radios comunitarias, y sólo algunas de ellas eran de carácter indígena. Aunque escasas, estas radios han fungido como una herramienta real en el ejercicio de la libertad de expresión de los pueblos.

El vacío legal en que vivía la radio comunitaria y la radio indígena terminó con la reforma a la Constitución Política de los Estados Unidos Mexicanos (CPEUM) en materia de telecomunicaciones de 2013, en la que se reconoció por primera vez la existencia de las radios comunitarias e indígenas.

Con la reforma, ambas figuras, concesionarias y permisionarias, se unificaron en concesiones, de las que se establecieron cuatro tipos: de uso comercial, de uso público, de uso privado y de uso social. Dentro de esta última figura es donde por primera vez se mencionan e incluyen en el marco legal a las radios de uso social comunitarias y las radios de uso social indígena.

La inclusión de las radios indígenas sentaba un paso adelante en el cumplimiento al mandato del artículo 2o. constitucional que señala, a partir de la reforma en materia indígena, que las autoridades tienen la obligación de "establecer condiciones para que los pueblos y las comunidades indígenas puedan adquirir, operar y administrar medios de comunicación en los términos que las leyes de la materia determinen". ${ }^{8}$

Al emitirse la Ley Federal de Telecomunicaciones y Radiodifusión (LFTyR) en 2014, diversas organizaciones de la sociedad

7 Asociación Mundial de Radios Comunitarias (AMARC-México), Segundo informe sobre la situación de la radiodifusión comunitaria en México, 2014, p. 10, consultado en: http://wwre.amarcmexico.org/phocadownloadpap/2do_informe_amarc_2014. $p d f$.

8 Artículo 2o., fracción VI, inciso b, de la Constitución Política de los Estados Unidos Mexicanos. 
civil consideraron que su contenido "significó un retroceso de la propia reforma constitucional al regular de manera discriminatoria, desproporcional y restrictiva a las radios comunitarias e indígenas, en relación con el resto de las concesiones sociales, las públicas y las comerciales". ${ }^{9}$ La Asociación Mundial de Radios Comunitarias, AMARG-México, ubica criterios discriminatorios principalmente en tres artículos de la LFTyR.

El primero de ellos es el artículo 85, en el cual se enlistan los requisitos para quienes soliciten una concesión de uso social, y se señala que el Instituto Federal de Telecomunicaciones (IFT) puede solicitar requisitos adicionales a los enlistados (a su juicio), situación que violenta las garantías de legalidad y seguridad jurídica de los solicitantes.

El segundo criterio discriminatorio se ubica en el artículo 89, que limita las fuentes de las cuales las radios de uso social comunitarias e indígenas pueden obtener ingresos. AMARC crítica la prohibición para acceder a publicidad comercial como vía de obtención de recursos que permita la sustentabilidad de las emisoras. En cambio, se menciona que sólo podrán acceder hasta al 1\% del gasto en comunicación social de las dependencias federales, vía la difusión de publicidad oficial. Además de no establecerse la obligatoriedad del otorgamiento de este recurso, este porcentaje resulta discriminatorio respecto al que acceden otro tipo de concesiones. El recibir recursos oficiales también podría generar una relación de codependencia financiera de las radios comunitarias e indígenas con entidades gubernamentales, además de que esta codependencia podría generar el sesgo en la libertad de expresión.

El tercer criterio discriminatorio se ubica en el artículo 90 de la LFTyR, que relega a las emisoras comunitarias e indígenas a las altas frecuencias. "Esta restricción es discriminatoria, pues en algunos lugares del país esas frecuencias están ya ocupadas, con

9 Asociación Mundial de Radios Comunitarias (AMARC-México), op. cit., p. 15 . 
lo cual se les impediría la entrada a este tipo de emisoras". ${ }^{10}$ Ese mismo artículo indica que el IFT sólo reservará el 10\% de la banda de radiodifusión sonora para radios de uso social indígena y comunitaria, lo cual violenta el principio de igualdad ante la ley. Además, con la propuesta de reducción en la separación entre estaciones de los 800 a los $400 \mathrm{MHz}$ se duplicaría la cantidad total de frecuencias a ocupar, por lo que limitar el uso del espectro al $10 \%$ resulta inequitativo.

Otro elemento de crítica son las dilaciones administrativas y las negativas a las solicitudes de concesión de uso social indígena. Esto se ha traducido en que a diciembre de 2017, de 23 solicitudes sólo se hayan otorgado seis concesiones de este tipo. ${ }^{11} \mathrm{~A}$ estos criterios discrecionales se suma la dificultad práctica de las comunidades para acceder a información sobre los trámites, la cual, de manera discriminatoria, sólo se puede obtener vía Internet. Además del hecho de que no existen oficinas del IFT en los estados, lo cual requiere que los solicitantes viajen a la Ciudad de México. A esto se suma la imposibilidad real de muchas comunidades indígenas de reunir los requisitos solicitados.

\section{CRIMINALIZACIÓN DE LAS RADIOS INDÍGENAS}

El reconocimiento legal de las radios indígenas se presenta ante la opinión pública como una apertura estatal hacia una mayor democratización mediática. Sin embargo, en la práctica no se generan las condiciones reales para que los pueblos indígenas ejer-

\section{Ibidem, p. 19.}

11 De éstas, tres son transiciones de radio permisionarias: Radio Ach' Lequilc' Op, 98.7 FM, de Bachajón, Chiapas (Tzeltal); Radio Nahndiá, 107.9 FM, Mazatlán Villa de Flores, Oaxaca (mazateca); Radio Jënpoj, 107.9 FM, Tlahuitoltepec, Oaxaca (Mixe). Así como tres nuevos otorgamientos a: $97.3 \mathrm{FM}$, Ocumicho, Michoacán (purépecha); Estéreo Lluvia, Villa Tututepec, Oaxaca, 106.1 FM (mixteca); Radio comunitaria Zacatepec-Tlaxcalancingo, 107.1 FM, Puebla (náhuatl). 
zan su derecho a comunicar de manera igualitaria al resto de la población.

Además de los criterios discriminatorios en el acceso al uso del espectro radioeléctrico, el hecho de que existan criterios discrecionales a la hora de decidir quiénes sí y quiénes no pueden ser acreedores a las concesiones abre la puerta para legalizar la represión hacia las emisoras que resulten incómodas para las autoridades.

En primera instancia, a aquellas radios a las que no les sea otorgada una concesión se les pueden decomisar sus "bienes, instalaciones y equipos", según lo asienta el artículo 305 de la LFTyR. Esta norma resulta inconstitucional, pues contraviene, además de múltiples tratados internacionales suscritos por México, lo establecido en el artículo 7o. de la CPEUM que menciona que en ningún caso podrán secuestrarse los bienes utilizados para la difusión de información, opiniones e ideas, como instrumento del delito.

El artículo 305, así como la campaña persecutoria del IFT de 2016 ("Se busca por robo. Transmitir desde una estación de radio sin concesión es un delito") han motivado posicionamientos infames como la del diputado priísta Benjamín Medrano. Éste promovió una iniciativa, ya aprobada por la Comisión de Radio y Televisión, que busca modificar la LFTyR y el Código Penal Federal para imponer hasta seis años de cárcel, de 100 a 300 días de multa y el decomiso de los bienes para todas aquellas personas que usen el espectro radioeléctrico sin concesión, penas sólo antes vistas durante la dictadura militar chilena.

Lo propuesto por Medrano es desde hace tiempo una realidad para varios comunicadores indígenas críticos, a quienes se les han decomisado sus equipos y encarcelado con base en el artículo 150 de la Ley General de Bienes Nacionales. Estas penas ejemplares han sido también selectivas, como constata AMARC, que identifica que el mayor número de agresiones se dirigieron hacia comunicadores ligados a la defensa del territorio o en contra de megaproyectos como mineras y parques eólicos. 
$\mathrm{Al}$ precio de comunicar se suman múltiples violaciones a los derechos humanos, tales como: allanamientos, fabricación de delitos, agresiones físicas, detenciones arbitrarias, amenazas y ejecuciones extrajudiciales. Sobre esta última se puede mencionar el caso del locutor mixteco Salvador Olmos García, de la radio comunitaria Tuu Nuu Savi, de Oaxaca, quien fue torturado y asesinado por elementos de la policía municipal. Este patrón selectivo de represión hacia las personas que son parte de radios críticas se recrudecerá en aquellas estaciones indígenas a las que no se les otorgue una concesión, las cuales serán dejadas en la indefensión legal y, por lo tanto, más propensas a que se les violen sus derechos.

\section{LAS RADIOS LIBRES INDÍGENAS}

En el diverso panorama de radios indígenas es posible identificar dos posturas políticas principales respecto a la relación que estas emisoras buscan establecer con el Estado. Por una parte se ubican aquellas que pugnan por la mejoría de condiciones dentro del marco legal. Por la otra se encuentran las emisoras que consideran al espectro radioeléctrico como parte de su territorio, el cual observan como un componente indisociable para el ejercicio de la libre determinación. Éstas pugnan por una radiodifusión libre y autogestiva como elemento de reforzamiento de la defensa de sus derechos colectivos al territorio, a la cultura y a la autonomía, además de que basan su ejercicio en la legitimidad que les otorgan sus comunidades.

Dentro de los posicionamientos recientes de las radios libres indígenas destaca el informe que seis emisoras del estado de Guerrero entregaron, en diciembre de 2017, tanto a David Kaye (Relator Especial sobre la Promoción y Protección del Derecho a la Libertad de Opinión y de Expresión del Consejo de Derechos Humanos de la ONU), como a Edison Lanza (Relator Especial para la Libertad de Expresión de la Comisión Interamericana de Derechos Humanos de la OEA). 
En el marco de la visita de los relatores, las radios La Voz de los Pueblos, La Voz de la Costa Chica, Radio Voces Nuestras, Radio Tachi Ñu Itia Ta’nu, Radio Naxme y Radio Ñomndaa expresaron su posicionamiento referente a su ejercicio comunicativo:

- El ejercicio de nuestros derechos colectivos es un componente central en el ejercicio de nuestro derecho consuetudinario, usos, normas y costumbres que encuentran fundamento en una tradición de siglos aprendida-aprehendida de manera oral por nuestros antepasados, el cual se mantiene en tensión constante con el poder político que se sustenta en el derecho positivo.

- El Estado mexicano, en su afán por regular el uso, aprovechamiento y explotación del espectro radioeléctrico, promueve la concentración mediática, la usura y la hegemonía de la industria cultural impuesta por la modernidad capitalista.

- Nuestras radios comunitarias se han visto obligadas a transmitir al margen de la regulación federal por causa de un marco normativo diseñado para generar una alta concentración en la propiedad y control de los medios de comunicación, el cual, a pesar de las reformas en materia de telecomunicaciones y radiodifusión del año 2014, sigue sin ser un marco normativo que brinde certeza jurídica, que promueva la desconcentración de la radio y la televisión y mucho menos que genere un espacio mediático plural y accesible a todos los sectores de la población.

- Actualmente nuestras radios comunitarias son violentadas, amenazadas e intimidadas por las reformas aprobadas el pasado 4 de octubre de 2017 por la Comisión de Radio y Televisión del Congreso Federal con las que se pretende criminalizar el ejercicio de nuestros derechos a la libertad de expresión, opinión y comunicación.

- Frente a este panorama declaramos que, en tanto que el aire y el espectro radioeléctrico son parte indisociable de nuestro territorio, nos proponemos seguir ejerciendo nuestros derechos a la libre determinación y al territorio para garantizar un aprovechamiento justo y equitativo del espectro radioeléctrico dentro de nuestro territorio indígena que permita garantizar el pleno 
goce y ejercicio del derecho a la libertad de expresión, opinión y comunicación de nuestros pueblos indígenas. ${ }^{12}$

Las estaciones firmantes piden recomendar al Estado mexicano el respeto a la radiodifusión libre de los pueblos indígenas como pilar imprescindible de su reproducción cultural, además de la no criminalización de su ejercicio comunicativo, que consideran fundamental para el goce de su derecho a la libertad de expresión, opinión y comunicación.

\section{GONCLUSIÓN}

La carencia de justicia en el acceso a los medios se traduce en la monopolización de la información en manos de empresas privadas que tornan en mercancía a este bien público y violentan el derecho de las audiencias al ofrecerles contenidos homogéneos y sesgados.

A pesar de la apertura legal del 10\% del espectro radioeléctrico a las emisoras indígenas y comunitarias, que será difícil de garantizar en la práctica, la realidad de fondo es que persiste un acceso inequitativo a los medios de comunicación en el cual los pueblos indígenas son uno de los grupos más excluidos. Esta inequidad demuestra que el reconocimiento del carácter pluricultural de la nación no se respeta en la práctica, en la que prevalecen el monoculturalismo y el paternalismo como continuación del dispositivo de dominación hacia los pueblos indígenas.

Los candados en el acceso al espectro radioeléctrico por parte de las radios indígenas, así como el panorama de criminalización que está pujando por legalizarse, dan cuenta de que los discursos críticos generados desde las comunidades indígenas no tienen cabida en el proyecto de nación. En este sentido, es impe-

12 Fragmento del Informe conjunto de las radios comunitarias de Guerrero frente a las relatorías de libertad de expresión de la ONU y la OEA, 2 de diciembre de 2017, Chilpancingo, Guerrero, México. 
Esta obra forma parte del acervo de la Biblioteca Jurídica Virtual del Instituto de Investigaciones Jurídicas de la UNAM

rante que para el cumplimiento de una democracia efectiva estas voces sean reconocidas plena y dignamente.

\section{BIBLIOGRAFÍA}

\section{ASOGiaGión Mundial de Radios COMUnitarias (AMARG-} México), Segundo informe sobre la situación de la radiodifusión comunitaria en México, México, 2014.

Castells I Talens, Antoni, “ ¿Ni indígena ni comunitaria? La radio indigenista en tiempos neoindigenistas", Comunicación y Sociedad, México, núm. 15, enero-junio de 2011.

ESTEINOU MADRID, Javier, Los medios de comunicación y la construcción de la hegemonía, México, Trillas, 1992.

Gasparello, Giovanna, "No morirá la flor de la palabra... la radio comunitaria indígena en Guerrero y Oaxaca", Nueva Antropología, México, vol. XXV, núm. 77, julio-diciembre de 2012.

REgINO-MONTES, Adelfo, "Diversidad y autonomía. Un aporte desde la experiencia indígena mexicana", Renglones, Jalisco, México, núm. 56, 2004. 
Fecha: / /

No olvidar.. 
Fecha: / /

No olvidar.. 
Diálogos diversos para más mundos posibles, editado por el Instituto de Investigaciones Jurídicas de la UNAM, se terminó de imprimir el 23 de julio de 2018 en los talleres de Desarrollo Gráfico Editorial, S. A. de C. V., Municipio Libre 175A, colonia Portales, delegación Benito Juárez, 03300 Ciudad de México, tel. 5601 0796. Se utilizó tipo Baskerville en 9, 10 y 11 puntos. En esta edición se empleó papel cream book 57 x 87 de 60 gramos para los interiores y cartulina couché de 250 gramos para los forros. Consta de 500 ejemplares (impresión offset). 

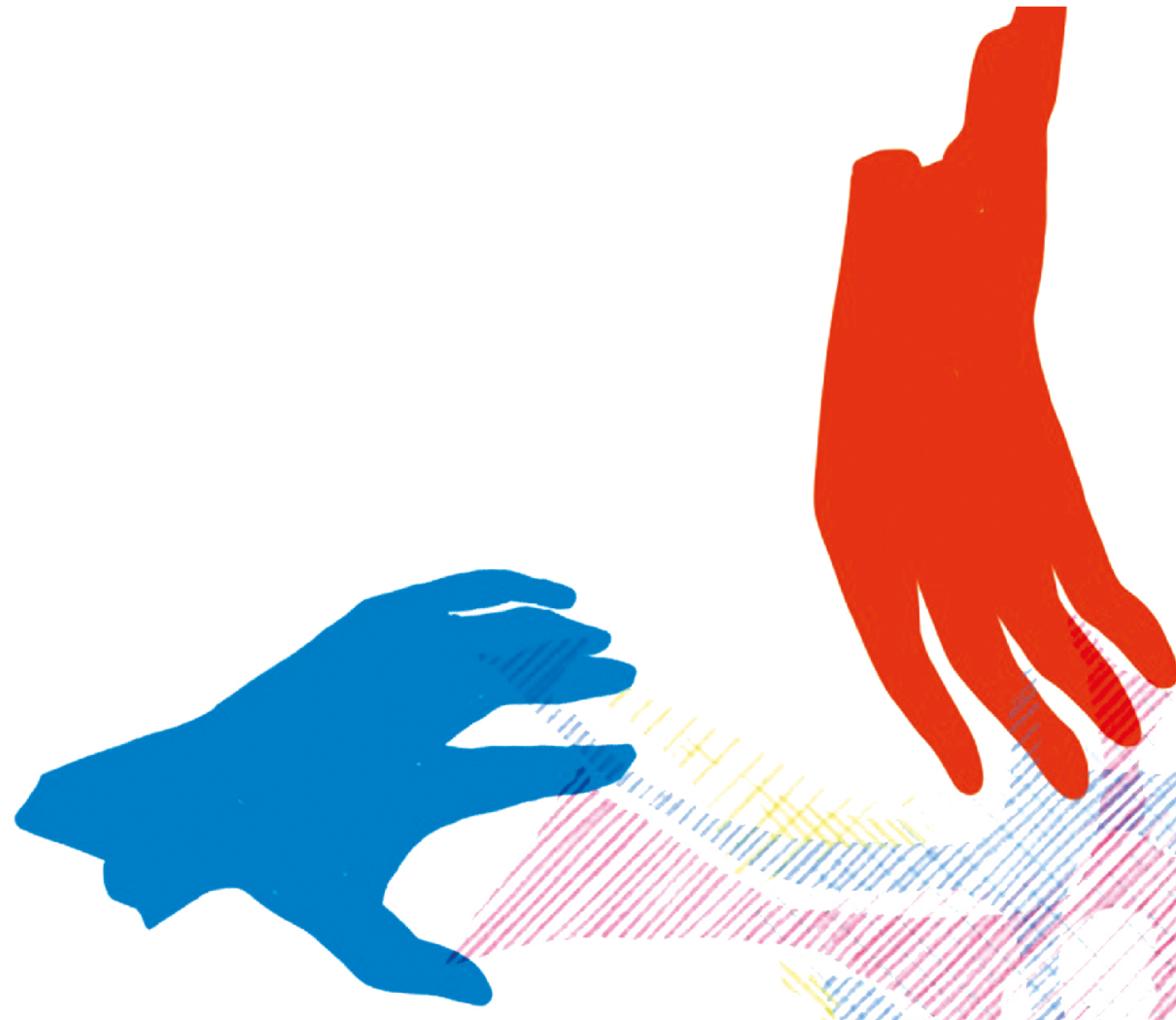

ISBN 978-607-30-0069-7
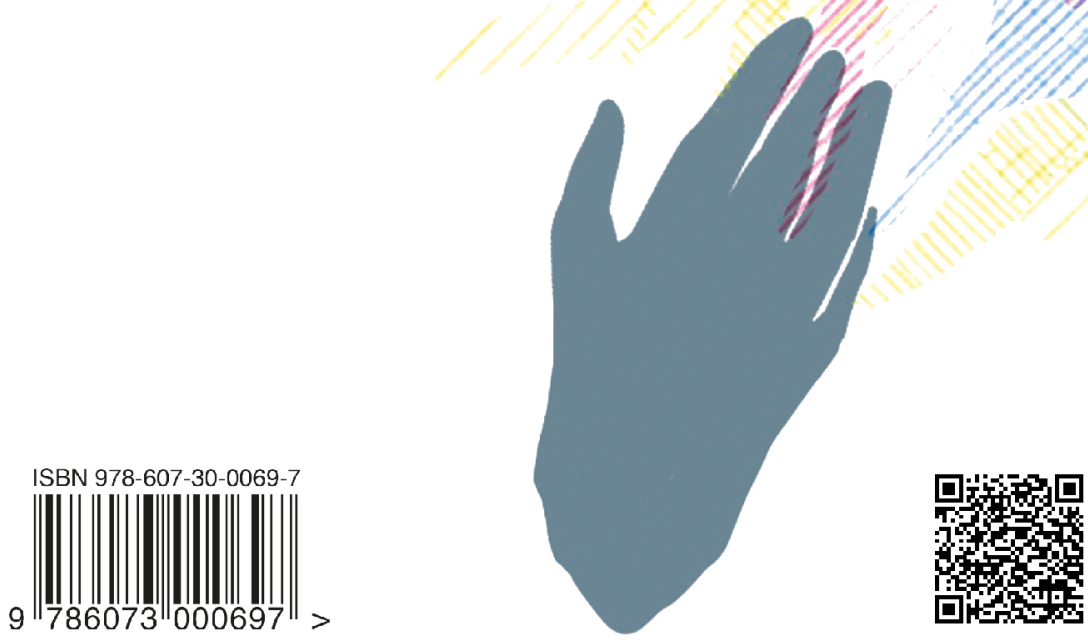